






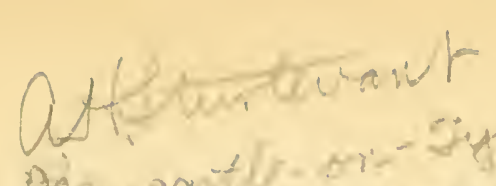

$$
\begin{aligned}
& \text { Dewently-pr--5ye } 1933
\end{aligned}
$$

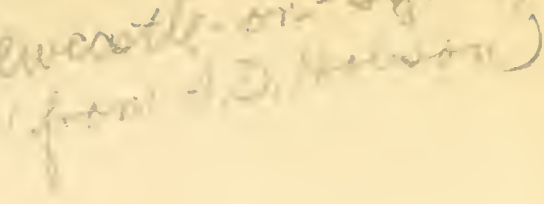




\section{BY T'HE SAME AU'HOR.}

Royal 8vo. In 4 parts, eaeh, with 25 Coloured Plates, 15s., or complete in one vol. $63 s$.

\section{CONTRIBUTIONS TO THE FLORA OF MENTONE, AND TO A}

WINTER FLORA OF THE RIVIERA, Including the Coust from Marseilles to Genou.

J. TRAHERNE MOGGRIDGE, F.L.S.

L. REEVE \& C0., 5, HENRIETTA STREET, COVENT GARDEN. 


\title{
HARVESTING ANTS
}

\author{
AND
}

\section{TRAP-DOOR SPIDERS.}





\section{HARVESTING ANTS}

AND

\section{TRAP-DOOR SPIDERS.}

NOTES AND OBSERVATIONS ON THEIR

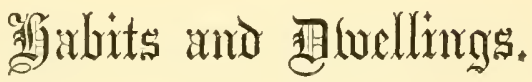

BY

J. TRAHERNE MOGGRIDGE, F.L.S.

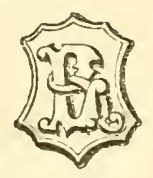

LONDON :

L. REEVE \& CO., 5 , HENRIETTA STREET, COVENT GARDEN. 



\section{CONTENTS.}

$$
\text { P A R T } 1 \text {. }
$$

HARVESTING ANTS

$$
\text { PART II. }
$$

TRAP-DOOR SPIDERS . . . . . . . . . 71 



\section{EXPLANATION OF PLATES.}

\section{PART I.-HARVESTING ANTS.}

Plate I., p. 21, fig. A.- Tiew of the entrance to a nest of Atta barbara, showing part of a train of ants bearing seeds, the conical mound of refuse thrown out, and some seedlings, which have sprung up from seeds accidentally dropped by the auts; $B$, one of the larger workers of this species, of the natural size, and B 1 , its abdomen and pedicle, with two nodes, magnified; $\mathrm{C}^{*}$, one of the smaller workers, of the natural size; C, a male, of the natural size; D, a female, of the natural size; D 1, wing of the same, magnified; I 2, mouth organs of the same, magnified, with the mandibles removed, the two outer pieces being the maxillæ and their palpi, and the lozenge-shaped piece the labium, from the npper part of which the labial palpi spring, while behind the labium is the true tongue; D 3, one of the mandibles, magnified; E, a larva, of the natural size, and E 1 , the same, magnified.

Plate 1I., p. 22, fig. A.-A trowel containing eartl, in which a granary full of seeds is lying almost undisturbed, of the natural size; B, the crater-like entrances found at the mouths of the nests of Atta structor, reduced to one-half the natural size.

Plate III., p. 23.-The floors of three granaries of Alta burbara, surrounded by the much coarser gravelly earth, of the natural size.

Plate IV., p. 31.-A mass of earth piercel by roots, in which the ants (Atta barbara) have made their granaries and galleries. The galleries were full of seeds when first laid open. Of the natural size.

Plate V., P. 33, fig. A.-Galleries and terminal cells of a nest of Atta barbara, excavated in the living sandstone rock, drawn in situ, of the natural size; $\mathrm{B}$, part of a cylindrical gallery from another rock-nest, and B 1 , the same gallery seen in front, of the natural size.

Plate VI, 1. 35, fig. A.-A sprouting hempseed, part of the radicle of which has been gnawed by the ants, of the natural size; A 1, the same, magnified, rad. radicle; A 2, an entire sprouting seer of the same, magnified; $\mathrm{B}$, a sprouting pea, part of the radicle of which has been gnawed off; B 1, the same, magnified; B 2, the same stripped of its 
coat, and showing the two seed leaves; C, a sprouting "canary-seed" (the grain of Phalaris canariensis), part of the fibril of which has been gnawed off; $\mathrm{C}$ 1, the same, magnitied, rad. the radicle which remains undeveloped, and $f i b$. the fibril or first rootlet; C 2, an unmutilated sprouting "canary seed ;" D, a mass of earth taken out of the heart of a nest of Atta barbara, in which a spherical cell, made of hardened earth, was buried. It contained grass seeds, among which I found ants at work, and seeds of the same grass still in their husks lay in the gallery leading up to the entrance of this cell; D 1, the same, further freed from the earth, and having part of one side removed, so as to show the interior and the small lower opening leading out from the bottom of the cell.

\section{PART II-TRAP-DOOR SPIDERS.}

I'LATE VII., p. 88, fig. A.-The nest of Cteniza fodiens, the lower part of which is seen in section lying in the earth, the door is artiticially represented as partly open; A 1, surface of the door viewed from above; A 2, the spider; A 3 , the spider deprived of its legs, from a specimen preserved in spirits [figs. A, A 1, A 2, and A 3, are of the natural size]; A 4, the spiller viewed sideways, with the legs removed; A 5, the eyes, viewed from above and in frout; $A$, the cephalothorax and falces; A 7 , the left hand falx, viewed from the inuer side; A 8, the fang of the same; A 9, the tarsal joint of the foremost right leg; A 10, one of the two larger and the smallest claw of the same [figs. A 4, 5, 6, 7, 8, 9, and 10, all magnified]. Fig. B, the door of a nest of the same kind, concealed by lichens, below which, on the left hand, the doors of two minute nests of Nemesia meridionalis are seen; B 1, the same, with the doors open; $\mathrm{C}$, the door and mouth of tube of a nest similar to that at $\mathrm{A}$; C 1, the upper surface of this door, which is slightly convex.

Plate ViII., p. 94, fig. A.-The nest of Nemesia comentaria; A 1, the door of the same, partially open; A 2, the spider; A 3, the same deprived of its legs, from a specimen preserved in spirits [figs. A, A 1, 2 , and 3 , of the natural size]; figs. A 4, 5, 6, 7, 8, 9, and 10 as in Plate VII., and magnified; B, a moss-covered lump of earth, in which the door of a nest of the same type as that at A lies concealed; B 1, the same, with the door open; C, the door and mouth of another similar nest, showing the claw marks on its under surface; D, the closed door of a third nest of the same kind; D l, the same, opened.

Plate IX., p. 98, fig. A.-The nest of Nemesia meridionalis; A 1, the open surface-door and mouth of the tube of the same; A 2, the inner and upper surface of the lower door; A 3, the spider; A 4, the same deprived of its legs, from a specimen preserved in spirits [figs. A, A 1, 2, 3, and 4 are of the natural size]; A 5, the spider viewed sideways, with the legs 
removed; A 6 , the eyes, viewed from above and in front; $A$, the cephalothorax and falces; A 8 , the left hand falx viewed from the inner side; A 9, the fang of the same; A 10, the tarsal joint of the foremost right leg; A 11, one of the two larger and the smallest claw of the same [figs. A $5,6,7,8,9,10$, and 11 , magnified]; $B$, a mass of earth containing the minute nest of a young spider ( $N$. meridionalis); B 1, the lower door of this nest; B 2, the spider [figs. B, B 1, and 2, of the natural size].

Plate X., p. 100, fig. A.-Part of a nest of $N$. meridionalis; $\mathrm{B}$, the new and larger upper door of a nest of this spider, with the former and smaller upper door partially united to it ; $C$, another example of enlargement in the upper door of the same spider, showing traces of two previous doors now incorporated. [All the figures are of the natural size.]

Plate XI., p. 105, fig. A.-The upper part of a nest of N. meridionalis concealed in a plant of Ceterach fern; A 1 and A 2, a minute cork-door, closed and open, which I saw constructed by a very young spider [either Cteniza fodiens, or, more probably, Nemesia cementaria] at the mouth of a hole in the mass of earth containing the nest of $N$. meridionalis figured at A. This hole may be seen on the right of the fern. B, the door of a small nest of $N$. meridionalis, as seen from above, in its natural position in a steeply sloping bank ; B I, part of the same nest placed in an upright position, and showing the surface door open and the lower door closing the branch; B 2, the same with the lower door pushed across so as to close the main tube; B 3,4, and 5, different views of this second door. [All the figures in this plate are of the natural size.]

Plate XII., p. 106, fig. A.-The nest of $N$. Eleanora with the surface door artificially represented as being open; A 1 , the outer side of the surface door of the same nest into which mosses of two kincls are woven; A 2, the second door of the same nest; A 3, the spider; A 4, the same deprived of its legs, from a specimen preserved in spirits [figs. A, A 1, 2,3 , and 4 are of the natural size] ; fig. A 5, the spider viewed sideways, with the legs removed; A 6 , the eyes viewed from above and in front; A 7. the cephalothorax and falces; A 8, the left-hand falx viewed from the inner side; A 9, the fang of the same; A 10, the tarsal joint of the foremost right leg; A I1, one of the two larger and the smallest claw of the same [figs. A 5, 6, 7, 8, 9, 10, and 11 , magnified]; fig. B and B 1, the upper part of the tube and door of a nest of $N$. Eleanora which partially projected beyond the surface of the earth and was clothed with living moss. [Figs. $\mathrm{B}$ and $\mathrm{B} \mathrm{l}$ are of the natural size.] 



\section{PART I.}

\section{HARVESTING ANTS.}





\section{PARTI.}

\section{HARVESTING A N T S.}

IT was in May, 1869, that Mr. Bentham in his presidential address to the Linnean Society called attention to the want of reliable information as to the existence of such subterranean accumulations of seeds as are popularly supposed to account for the sudden appearance on railway cuttings, gravel from deep pits, and the like, of crops of weeds hitherto unknown in a district.

He suggested that it might repay the trouble if some accurate observers were to take this in hand, and investigate the matter both by examining samples of undisturbed soil taken from various depths,-when, if any seeds of moderate size were present and undecomposed, it would be tolerably easy to distinguish them,-and aiso by ascertaining what means of transport exist by which seeds may be scattered over exposed surfaces, and thus explain the difficulty without having recourse to hypothetical supplies of sound though long-buried seeds.*

* M. Kerner of Innspruck has lately adduced some facts bearing on the question of the transport of seeds by the wind, having examined the collections of animal and vegetable substances found on the icy surfaces of glaciers and the plants growing on moraines. Judging from the facts thus obtained, he attributes but a small influence to this agency, as the specimens dis- 
As I listened, the question occurred to me whether the ants, which I had observed carrying seeds to their nests at Mentone, might not be unconscious agents on a small scale, both in the distribution and the subterranean storing of seeds. When at a later time I made this suggestion to some of our leading naturalists, I learned with considerable surprise that the unanimous opinion of our highest modern authorities on the subject is opposed to the belief that European ants ever do systematically collect and make provision of seeds, and that the instances of such occurrences in tropical climates remain as isolated though undoubted facts which it is difficult to explain.

I was not then aware that towards the middle of last century the ancient belief, dating from the time of Solomon, that ants habitually show forethought and husbandry in the collection of supplies of seeds and grain had begun to be called in question, and that our most able observers, such as Huber, Gould, Kirby and Spence, and at the present day $\mathrm{Mr}$. Frederick Smith, had by close scrutiny of the habits of these creatures proved that, wherever personal investigation had enabled them to put the matter to proof, no trace of harvesting was found.*

covered belonged to the fauna and flora of the immediate vicinity, and not one of these specimens must needs liave come from a distance. See abstract of his paper in Garlener's Chronicle, Feb. 3, 1872, p. 143, and in 'Nature' for June 27, 1872, p. 164.

* I have myself on many occasions thrown seeds in the track of the common English ants, and my experience was, up to the past summer (1872), similar to that of the above-named naturalists, but I have lately, by the merest chance, become acquainted with a curious exception to this rule. It happened as follows. I was gathering some fresh capsules of the common sweet violet in a garden at Richmond, near London, and in pouring the seeds 
However, just as the ancient writers, judging from their own experience and from the reports of others, had erred in attributing to ants in general the habit of seed-storing possessed by certain species commonly found in the south, so have modern naturalists fallen into the mistake of denying it to any of the European species.

The older authors who lived in Greece and Italy, and the mediæval authors who drew their information in great measure from the former, being familiar with the fact that some ants habitually collect large supplies of seed, went so far as to assert, or to imply, that all European ants do so; the authors of the present day, on the other hand, generalizing too freely from their experience of ants found near their northern homes, maintained and maintain the very reverse.

So long as Europe was taught natural history by southern writers the belief prevailed; but no sooner

out of my hand into the paper bag made to receive them, a few were spilled on the ground. In a short time afterwards I was greatly surprised to see some of these spilled seeds in motion, being carried by the common black ant (Formica nigra) into its nest. On seeing this $I$ hastened to get some more fresh violet seeds, and also a quantity of seeds taken from ant's granaries at Mentone, and scattered these where the other seeds had lain. After watching for half an hour a few of the violet seeds were carried in, but not one of the granary seeds was removed, though these were examined with some curiosity. I repeated this experiment twice afterwards on a distinct colony of ants of the same kind and obtained exactly the same result. I opened the nest of the former colony on the day after they had carried in the seeds, but failed to find these or any stores of other seeds.

I am inclined to think that the ants took these seeds believing them to be larvæ of other ants which they might eat; for fresh seeds of violet are not very unlike the larvæ of certain ants, as, for example, those of Atta barbara, figured at Plate I., Fig. E.. 1. 21, the semi-transparent membranous appendage partly concealing the seel and giving it a fleshy appearance.

I think this the more likely because on two occasions the seeds which had been carried into the nest were subsequently throwu out by the ants, which had I believe discovered their mistake. 
did the tide begin to turn, and the current of information to flow from north to south, than the story became discredited.

It is interesting now to recal a few of the allusions to the harvesting ants made by ancient authors, some of which contain tolerably accurate accounts of what was to them a familiar sight or a universally accepted fact.

The passages in Proverbs" are the following : "Go to the ant, thou sluggard: consider her ways and be wise; which, having no guide, overseer, or ruler, provideth her meat in the summer, and gathereth her food in the harvest." "The ants are a people not strong, yet they prepare their meat in the summer." Hesiodt speaks of the time

"When the provident one (the ant) harvests the grain."

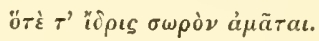

Horace $\ddagger$ also alludes to the foresight of the ant, who is "haud ignara ac non incauta futuri." Virgil\$ compares the Trojans hastening their departure to harvesting ants, and the passage has been thus rendered by Dryden :-

"The beach is covered o'er

With Trojan bands, that blacken all the shore:

On every side are seen, descending down,

Thick swarms of soldiers, loaden from the town,

Thus, in battalia, march embodied ants,

Fearful of winter, and of future wants,

* vi. 6-8 and $\mathrm{xxx}, 25$.

+ Works and Days, 776. \$ \$ Satires I. i. 33.

$\S$ Eneid, Bk. iv. 1. 402.

"Ac velut ingentem formicæ farris acervum

Quum populant, hiemis memores, tectoque reponunt:

It nigrum campis agmen, predamque per herbas

Convectant calle angusto; pars grandia trudunt

Obnixæ frumenta humeris; pars agmina cogunt,

Castigantque moras ; opere omnis semita fervet." 
'T' invade the corn, and to their cells convey

The plundered forage of their yellow prey.

The sable troops, along the narrow tracks,

Scarce bear the weighty burden on their backs;

Some set their shoulders to the ponderous grain;

Some guard the spoil ; some lash the lagging train;

All ply their several tasks, and equal toil sustain."

Indeed, it would seem that among the people inhabiting the shores of the Mediterranean it was almost as common to say "as provident as an ant" as it is with us to say "as busy as a bee." Plautus" introduces a slave who, when attempting to account for the rapid disappearance of a sum of money of which he had charge, says,

"Confit cito

Quam si tu objicias formicis papaverem."

"It vanished in a twiukling,

Just like poppy seed thrown to the ants."

Any one who has seen the eagerness with which certain southern ants seize upon seeds thrown in their path will appreciate the correctness of this simile.

Claudius Flianus, who lived in the time of Hadrian, gives a detailed account of the habits which he attri. butes to ants, $\uparrow$ from which the following is a translation: "In summer time, after harvest, while the ears are being threshed the ants pry about in troops around the threshing floors, leaving their homes, and going singly, in pairs, or sometimes three together. They then select grains of wheat or barley, and go straight home by the way they came. Some go to collect, others to carry away the burden, and they avoid the way for one another with great politeness and consideration, especially the unburdened for the weight

* Trinummus, Act ii. sc. 4, 1. 7.

$\dagger$ Elian, De Naturâ Animalium, ii. 25. 
carriers. Now these excellent creatures, when they have returned home, and stored their granaries with wheat and barley, bore through each grain of seed in the middle; that which falls off in the process becomes a meal for the ants, and the remainder is unfertile. This these worthy housekeepers do, lest when the rains come the seeds should sprout, as they would do if left entire, and thus the ants should come to want. So we see that the ants have good share in the gifts of nature, in this respect as well as others." Further on* he gives a very interesting account of their mode of collecting and preparing the grain, many details of which I can myself substantiate from personal observation, though $I$ have never seen ants actually at work upon the ears of corn. "But when the ants start a foraging, they follow the biggest, who take the lead as generals. And when they come to the crops, the younger ones stand under the stalk, but the leaders ascending gnaw through the culms, as they are called [ovoayous, "the stalk ends on which the ears grow" (Lid. and Scott, Gr. Lex.), probably meaning that they detach the separate spikelets of

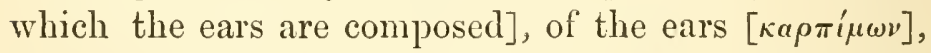
which they throw to the people below. These busy themselves with cutting away the chaff and peeling off the envelopes which contain and cover the grain. So the ants, though they need no threshing time, nor men to winnow for them, nor an artificial draught of wind to separate corn and chaff, yet have the food of men who both plough and sow for it." Elian appears also to have heard reports of the habits of ants in

* Alian, De Nat. Anim., lib. vi. chap. xliii. 
tropical countries, for he says, " Certainly the Indian ant is also a wise creature. ... . They leave one opening at the top (of the nest), by which they have their exits and entrances, when they come bearing the seeds which they collect." I have never myself found seeds bored through the centre in the way recorded above, but it is possible that different species of ants may treat the seeds in other ways than those observed by me; or, on the other hand, Elian may have mistaken the gnawing off the radicle of the seed, a process which I shall describe from personal observation below, and imagined that the seed itself was pierced.

Aldrovandus, writing in the sixteenth century, speakst of the ants as storing seed and of their guawing, "illud principium seu acumen grani, è quo germen emitti à tritico solet" - that is to say, the radicle. But it is not clear whether Aldrovandus treats of what he has himself seen or refers to the account given by a certain Bishop, Simon Mariolus, who, he says " in his most pleasant and learned work, introduces a philosopher as taking his walks abroad and examining an ant's nest with its seed store," \&c.

The lively fable of the ant and the grasshopper, as related by La Fontaine, has done much towards familiarizing and keeping alive in the minds of many of us the idea that ants habitually provide stores against the winter; but we must not infer from this narration that the witty French author had ever cared to examine for himself whether the fable, which he borrowed from Esop, had its foundation in fact or not. The 
following translation from the Greek original* bears in a much higher degree the impress of personal and accurate observation.

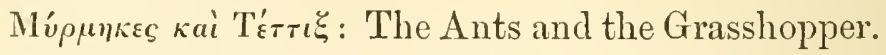
Once in winter time the ants were sunning their seedstore which had been soaked by the rains. A grasshopper saw them at this, and being famished and ready to perish, he ran up and begged for a bit. To the ant's question, "What were you doing in summer, idling, that you have to beg now?" he answered, "I lived for pleasure then, piping and pleasing travellers." "O, ho!" said they, with a grin, "dance in winter, if you pipe in summer. Store seed for the future when you can, and never mind playing and pleasing travellers." $\dagger$ It would be easy to multiply instances in which the older anthors allude to this habit, but enough have been given to afford a sample of what may easily be found repeated elsewhere, and I will now quote a few instances which illustrate the more modern belief, utterly opposed to that so long maintained by the ancients.

Messrs. Kirby and Spence $\neq$ discuss the matter in the following terms:- "When we find the writers of all nations and ages unite in affirming that, having deprived it of the power of vegetating, ants store up grain in their nests, we feel disposed to give larger credit to their assertions. Writers in general have taken ... (this). . for granted. But when observers of nature began to examine the manners and economy of these

* For this translation and all the foregoing extracts from ancient and medieval authors I have to thank my brother, M. W. Moggridge.

$\dagger$ Esopice Fabulæ (Tauchuitz edition), p. 92.

† Entomology, ed. 7 (1856), p. 313. 
creatures more narrowly, it was found, at least with respect to the European species of ants, that no such hoards of grain were made by them; and, in fact, that they had no magazines in their nests in which provisions of any kinds were stored up."

They then proceed to explain how easily the white pupæ, which the ants carry about in their jaws, may have been mistaken for grains of wheat, and to inform us that the accurate observations of $\mathrm{Mr}$. Gould, published in 174\%, were among the first which led to the correction of this error. "However," they continue, " it may be otherwise with exotic ants, for although during the cold of our winters they are generally torpid and need scurcely any food, yet in warmer regions, during the rainy seasons, when they are probably confined to their nests, a store of provisions may be necessary for them."

The author of the article on ants in Smith's Dictionary of the Bible says, in reference to the assertion that ants store seed, that "observation of the habits of ants does not confirm this belief."

Latreille* denies it in the following emphatic terms: "N'attribuons pas à la fourmi une préroyance inutile: engourdie pendant l'hiver, pourquoi formeroit elle des greniers pour cette saison?"

Huber again throws the weight of his great authority into the scale against the ants, when he says, $\uparrow$ " I am naturally led to speak in this place of the manner in which ants subsist in the winter, since we have relinquished the opinion that they amass wheat and other grain, and that they gnaw the corn to prevent 
it from germinating." He then goes on to show how the ants are frequently torpid during the winter, and that when it happens that a few warmer days wake them up to life, they can always find a few aphides also on the alert; for, strange to say, the same degree of warmth which rouses the ants calls forth the aphides also. It would appear that ants in the northern parts of Europe feed on the honey-dew of aphides, and on animal matter when they can get it; and up to the present time the belief prevails among our modern naturalists that they are limited to the same diet in all parts of Europe.

It is now well known, however, that exceptions must probably be made in tropical countries, for the observations of Lieut.-Col. Sykes* and Dr. Jerdont have shown that many ants in India collect grain in large quantities, robbing the crops and plants cultivated in gardens, and even stealing seeds put away in drawers, the inference being that they employ them for food. The same observers have recorded how the ants may be seen after wet weather bringing out the grain to dry in the sun.

Dr. Lincecum has also given a very interesting account $\ddagger$ of the habits of the "agricultural ant" inhabiting Texas, Myrmica (Alta) barbata, which not only stores the grain of a particular rice-like grass, but is said

* Lient.-Col. Sykes, Description of New Indian Auts, in Trans. Ent. Soc. Lond., i. 103 (1836), where a single species of ant, which he names Attu providcus, is described, and its habit of barvesting recorded.

+ Dr. Jerdon, Madras Journal Lit. and Sc. (1851), where three species are stated to harvest seeds on a large scale-namely, (Ecodoma (or Atta) providens, Ecodoma diffusa, and Atta rufa, all of which belong to the same section of ants as our Mentonese harvesters, Atta barbara, Atta structor, and Pheidole (or Atta) meyucepluala. These very interesting observations of Dr. Jerdon's, as well as those of Lient.-Col. Sykes, will be found in Appendix B.

$¥$ Published in the Journal of the Linnean Society of London, vol. vi. p. 29. 1861 . 
to maintain a clean crop of this plant around its nest, suffering no weed to appear among it, and harvesting the crop in its proper season.

The Sauba ant (Ecodoma ceplialotes) has been seen by $\mathrm{Mr}$. Bates plundering baskets containing mandioca meal (an impure form of tapioca) in Brazil, and this in so wholesale a manner as shortly to threaten the loss of the entire supply; and Dr. Delacoux records* the presence in New Granada of a monstrous ant, called by the natives Arieros, a word which, I am informed, is of Arabic extraction, and means the carrier, which ensptied an entire sack of maize belonging to him in a single night.

It seems strange that while travellers have reported the seed-storing habits of ants in far distant countries, our naturalists at home should have not only remained unaware of its existence in Europe, but even strenuously denied it. It is certain, however, that naturalists and others in southern Europe are more or less aware of the fact, but I have been unable to learn that any accurate account of the habits of harvesting ants has hitherto been published, or that any one has taken pains to discover what becomes of the seed so laboriously obtained.

It is true that in the Enciclopedia Popolare $\dagger$ extracts are given from the remarks made by Mr. Gené + on the subject, in which he assumes that the fact that ants collect and carry to their nest large supplies of grain and seed is well known, but states that he is at

* Notice sur les Mcurs et les Habitudes de quelques Espèces de Formiciens des Climats Chauds. Rev. Zool., Mai, 1848, p. 1849.

+ Article Formica, vol. v. p. 143-4. (Turin, 1845).

$\ddagger$ Memorie per servire alla Storia Naturale di alcuni imenotteri, published at Modena, in 1842. 
a loss to conceive how they employ them, unless it may be that they use them as materials for the construction of their galleries, for they cannot eat such hard substances, all their food being either liquid or of the nature of juices, "gli alimenti sono sempre materie liquide o materie sugose. Quanto ai corpi duri e secchi che le formiche raccolgono, io non so altrimenti riguardarli che come materiali di costruzione." It will be understood, I think, from what has gone before, that thus far nothing has really been ascertained as to the exact state of the case; for though the Italian author just quoted was aware that certain ants in the Mediterranean region do store seed, his knowledge went no further. Nor am I aware that any French author has published an account of this habit and its object; and in a recent abundantly illustrated volume founded on a work by M. Emile Blanchard, I find, on the contrary, the following very emphatic denial of its existence :"The curious idea which appears to liave commenced in very remote times, and to have been carried down by trirlition, and which was assisted by the results of careless observations, concerning the habits of the ants in collecting and storing up provisions, as it were under the influence of a wise foresight, is evidently incorrect." * There was, therefore, clearly an opening here for close observation, and this I determined to do my best to supply.

When I set out again from England in October, 1871, on my way to Mentone, I had obtained an idea of some of the leading points which needed to be

* The Transformations of Insects : an adaptation for English readers of M. Emile Blanchard's Metamorphoses, Mcurs, et Instincts des Iusectes, 1) 196. London. 1871. 
cleared up, and I was greatly encouraged in my attempt by the interest expressed in the subject by several of our leading naturalists, among whom I may especially mention Mr. Frederick Smith.*

Plainly the first thing to do was to determine whether the seeds which I had watched the ants carry to their nests were separately stored in subterranean granaries, as they would be if the ant really provides for the future; or whether they were merely strewed here and there, or used as building materials.

Next I must, if possible, obtain conclusive evidence as to the use to which the ants put the seeds thus collected; whether they eat them or turn them to some other account. Again I must observe whether the seed-collecting ants also search for aphides, and what other kinds of food they obtain. Then another very interesting question remained-namely, whether all southern ants uniformly collect seed, and to the same extent, or whether the habit is peculiar to certain species.

These, and many other subjects of inquiry connected with them, readily suggested themselves to my mind, and it will now be my endeavour to show how far I have been able to throw light upon them.

The habits recorded in the following pages refer exclusively, unless special notice is given to the contrary, to Atta barbara, the black ant represented on Plate I. We have, as far as I am aware, only four bona fide harvesting ants on the Riviera-namely, Atta barbara under two forms, the one wholly black

* I am very greatly indebted to $\mathrm{Mr}$. Smith for much kind assistance, and especially for having named the specimens which I collected. 
the other red-headed; Atta structor, a creature very similar to barbara, but of a claret-brown colour; and a minute yellow ant, the large workers of which have gigantic heads, named Plecidole (or Atta) megacephala.

My renewed observations at Mentone were carried on from October, 1871, to May, 1872, and I was able during that interval to become a frequent visitor to a warm and sheltered valley, which lay but a few minutes' walk from the house in which I lived, and in which thirty nests of the most active of the seed-storing ants were to be found.

Full therefore of my intention to resolve this difficulty if possible, I set out on October 29,1871 , immediately after my return to Mentone, to revisit this valley, where, in the previous May, I had seen the ants busily engaged in cutting, carrying, and sorting their harvest.

The spot in question was a rough slope of soft sandstone rock, with accumulations of sandy soil in the hollows, covered with a sparse and scrubby vegetation, composed of Cistus (C. salvifolius), potherb thyme, black lavender (Lavandula stachas), spiny broom (Calycotome spinosa), overshadowed here and there by a few scattered stone and maritime pines, and intermixed with coarse grasses and some smaller plants.

Cultivated lemon terraces lay on the edge of the wild ground lower down in the valley, and at this season, as also in the late spring, these terraces were overgrown with a rank crop of weeds, most of which were in seed.

I had scarcely set foot on the garrigue, as this kind of wild ground is called, to distinguish it from 
meadows or terraced land, before I was met by a long train of ants, forming two continuous lines, hurrying in opposite directions, the one with their mouths full, the others with their mouths empty.

It was easy enough to find the nest to which these ants belonged, for it was only necessary to follow the line of ants burdened with seeds, grain, or entire capsules, which had their heads turned homewards, and there, sure enough, at about ten yards distance, and partly shaded by some small Cistus bushes, lay the nest, to and from the entrances of which the incessant stream of incomers and outgoers kept flowing.

The proceedings of the ants were the same as those previously observed in the late spring (April and May), the workers usually seeking their harvest at some distance from the nest, and going in search of it as far as the cultivated ground, where the crops of weeds were more abundant and more varied.

In a few cases, however, where the terraces were too far distant, they contented themselves with plundering the grasses, pea-flowers, honeywort, and the other denizens of the garrigue. In one case I was able to follow the thread-like column of workers from the nest to the weedy terrace where the plants grew from which they were gathering the seeds, and found that the nearly continuous double line measured twentyfour yards. Even this gives but an inadequate idea of the number of ants actively employed in the service of this colony, for hundreds of them were dispersed among the weeds on the terrace, and many were also employed in sorting the materials and in attending to the internal economy of the nest. Still 
this affords some evidence of the systematic and extensive scale on which foraging is carried on by this ant, and of the high importance which these creatures attach to their provision of grain.

It is not a little surprising to see that the ants bring in not only seeds of large size and fallen grain, but also green capsules, the torn stalks of which show that they have been freshly gathered from the plant. The manner in which they accomplish this feat is as follows. An ant ascends the stem of a fruiting plant, of Shepherd's-purse (Capsella Bursa pastoris) let us say, and selects a well-filled but green pod about midway up the stem, those below being ready to shed their seeds at a touch. Then, seizing it in its jaws, and fixing its hind legs firmly as a pivot, it contrives to turn round and round, and so strain the fibres of the fruit-stalk that at length they snap. It then descends the stem, patiently backing and turning upwards again as often as the clumsy and disproportionate burden becomes wedged between the thickly set stalks, and joins the line of its companions on their way to the nest. In this manner capsules of chickweed (Alsine media) and entire calyces, containing the nutlets of Calaminth, are gathered; two ants also sometimes combine their efforts, when one stations itself near the base of the peduncle and gnaws it at the point of greatest tension, while the other hauls upon and twists it. I have never seen a capsule severed from its stalk by cutting alone, and the mandibles of this ant are perhaps incompetent to perform such a task. I have occasionally seen ants engaged in cutting the capsules of certain plants drop them and allow their companions below to carry them away; and this corre- 
sponds with the curious account given by Elian* of the manner in which the spikelets of corn are severed and

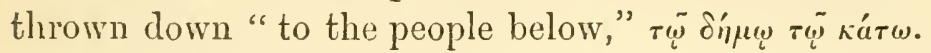

If the incoming and weight-carrying column of ants be closely examined it will be found that though the great majority of workers are bringing seeds in some form to the nest, a few are burdened with other and more miscellaneous materials.

Occasionally one or two may be detected carrying a dead insect, or crushed land-shell, the corolla of a flower, a fragment of stick, or leaf, but I have never seen aphides brought in to the nest or visited by this ant or by Atta structor.

It sometimes happens that an ant has manifestly made a bad selection, and is told on its return that what it has brought home with much pains is no better than rubbish, and is hustled out of the nest, and forced to throw its burden away. In order to try whether these creatures were not fallible like other mortals, I one day took out with me a little packet of grey and white porcelain beads, and scattered these in the path of a harvesting train. They had scarcely lain a minute on the earth before one of the largest workers seized upon a bead, and with some difficulty clipped it with its mandibles and trotted back at a great pace to the nest. I waited for a little while, my attention being divided between the other ants who were vainly endeavouring to remove the beads, and the entrance down which the worker had disuppeared, and then left the spot. On my return in an hour's time, I found the ants passing 
unconcernedly by and over the beads which lay where I had strewn them in apparently undiminished quantities; and I conclude from this that they had found out their mistake, and had wisely returned to their accustomed occupations.

I have often amused myself by strewing hemp and canary seed or oats, all of which form heavy burdens for the ants, near their nests; and it is a curious sight to watch the eagerness and determination with which they will drag them away. It is interesting also to note how on the following day the husks of these seeds will appear on the rubbishheap, or sometimes, after a shower of rain, they will be brought out by the ants with the point of the little root (the radicle or fibril as the case may be) gnawed off (see Figs. A, B, C, Plate VI., p. 35).

It frequently happens that on the wild hillside the position of a nest of Atta barbara is indicated by the presence of a number of plants growing on or round the kitchen midden, which are properly weeds of cultivation, and strangers to the cistus- and lavendercovered banks of the garrigue. These have sprung from seeds accidentally dropped by the ants, and which they had obtained from the lemon terraces. Thus when you see little patches of ground from one to three feet long and broad, covered with such plants as fumitory (Fumaria), oats (Avena), nettles (Urtica membranacea), four species of Veronica, chickweed (Alsine media), goosefoot (Chenopodium), Rumex Buceplualephorus, wild marigold (Calendula arvensis), Antirrhimum Orontium, Linaria simplex, and Cardamine hirsuta, you may confidently expect to find a colony of these ants close at hand. 



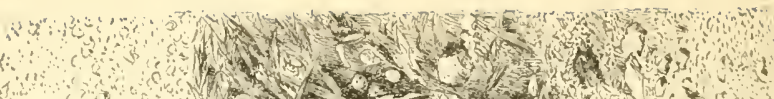
(1)

(3)

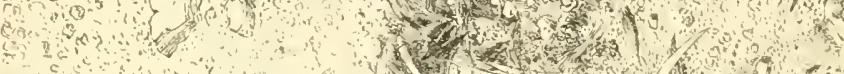
a

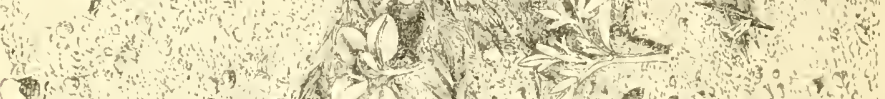
(3)

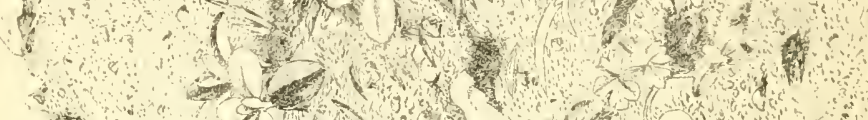
-

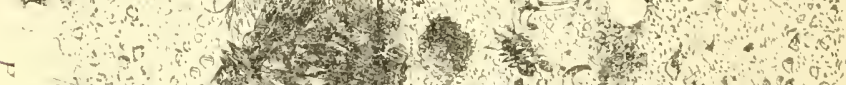

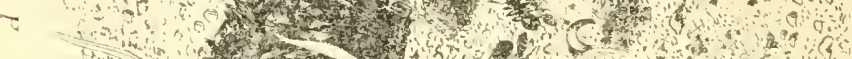

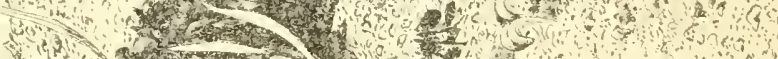
4.

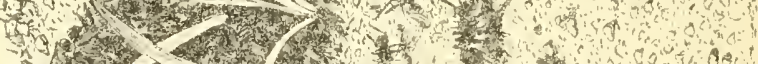

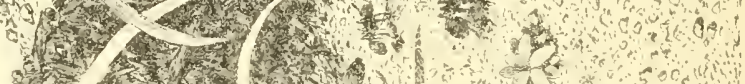

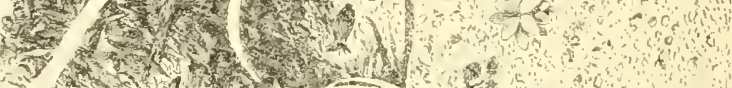

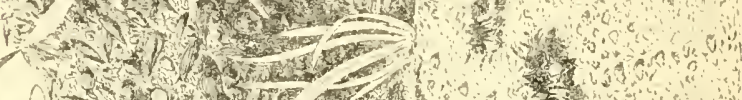

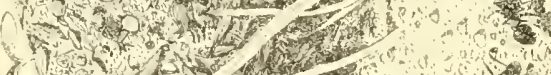

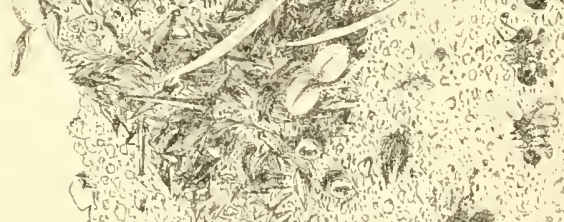

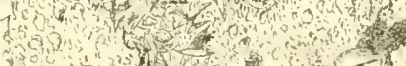
1. Hon

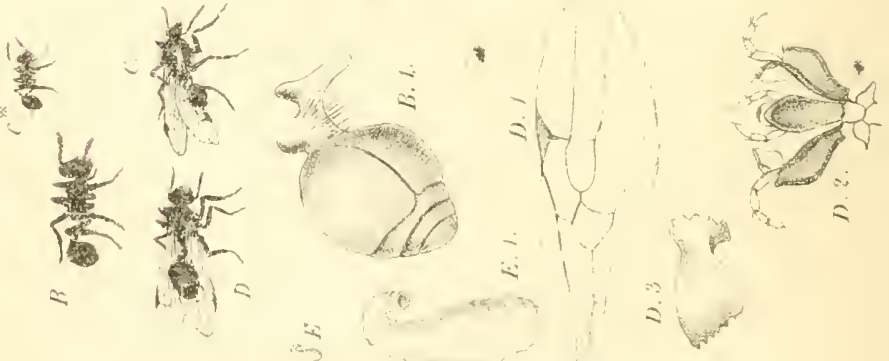


These plants are sometimes found along the sides of miniature gullies and crevices in the rock, where they have been washed by little runlets of water formed in seasons of heavy rain, and thus these interloping plants are occasionally dispersed and brought into competition with the rightful occupiers of the ground.

Atta structor and $A$. barbara do not employ any materials in the construction of their nest, simply excavating it out of the earth itself, or occasionally out of the sandy rock, and the large mounds, in great part composed of vegetable matter, which may frequently be found at the entrances of their nests, are nothing more than the rubbish heaps and kitchen middens of each establishment. These consist in part of the earth pellets and grains of gravel which the ants bring out from their nest when forming the subterranean galleries, but principally of plant-refuse such as the chaff of grasses, empty capsules, gnawed seedcoats, and the like, which would occupy much space if left inside the nest (see Plate I., Fig. A.). While an army of workers are employed in seeking and bringing in supplies, others are busy sorting the materials thus obtained, stripping off all the useless envelopes of seed or grain, and carrying them out to throw away. Thanks to the unwearied activity with which this divided labour is carried on the kitchen middens speedily rise in the harvest season, and in places where they are not exposed to the action of wind and rain, often acquire a considerable size, so much so that sometimes, if collected, one alone might fill a quart tankard.

It was the sight of such a refuse mound, and an examination of the materials which composed it,--many 
of which show that they were once parts of seeds, \&c.. the albuminous contents of which had been extracted through holes gnawed in the side,- - that gave me the conviction that large stores of seed must lie hidden below in the nest; for if it were true, as some have suggested, that the ants employ the grain and seeds which they collect as materials for the construction of their nest, they would certainly not reject such parts. as the chaff of grasses and the like, which are admirably suited for the purpose, and are actually used for this end by other species of ants.

It was therefore with the greatest confidence as to the result that I opened the nests of Atla barbara in search of granaries and seeds. My first attempt was made upon a nest lying in a hollow where there was a rather deep bed of soil, and the galleries extended so far on either side and in a downward direction that, though I removed enough soil to fill a wheelbarrow, I failed to reach the arcana of the nest, and saw neither chambers nor granaries.

Yet I frequently encountered workers carrying seeds downwards along the subterranean passages. I then selected a nest where the coarse and hard rock lay much nearer to the surface, barring their downward course, and compelling the ants to extend their nest in a horizontal direction.

Here, almost at the first stroke, I came upon large masses of seeds carefully stored in chambers prepared in the soil. Some of these lay in long subcylindrical galleries, and, owing to the presence in large quantities of the black shining seeds of amaranth (Amarantlus Blitum, \&c.), looked like trains of gunpowder laid ready for blasting. Fig. A, Plate II. represents a trowel- 

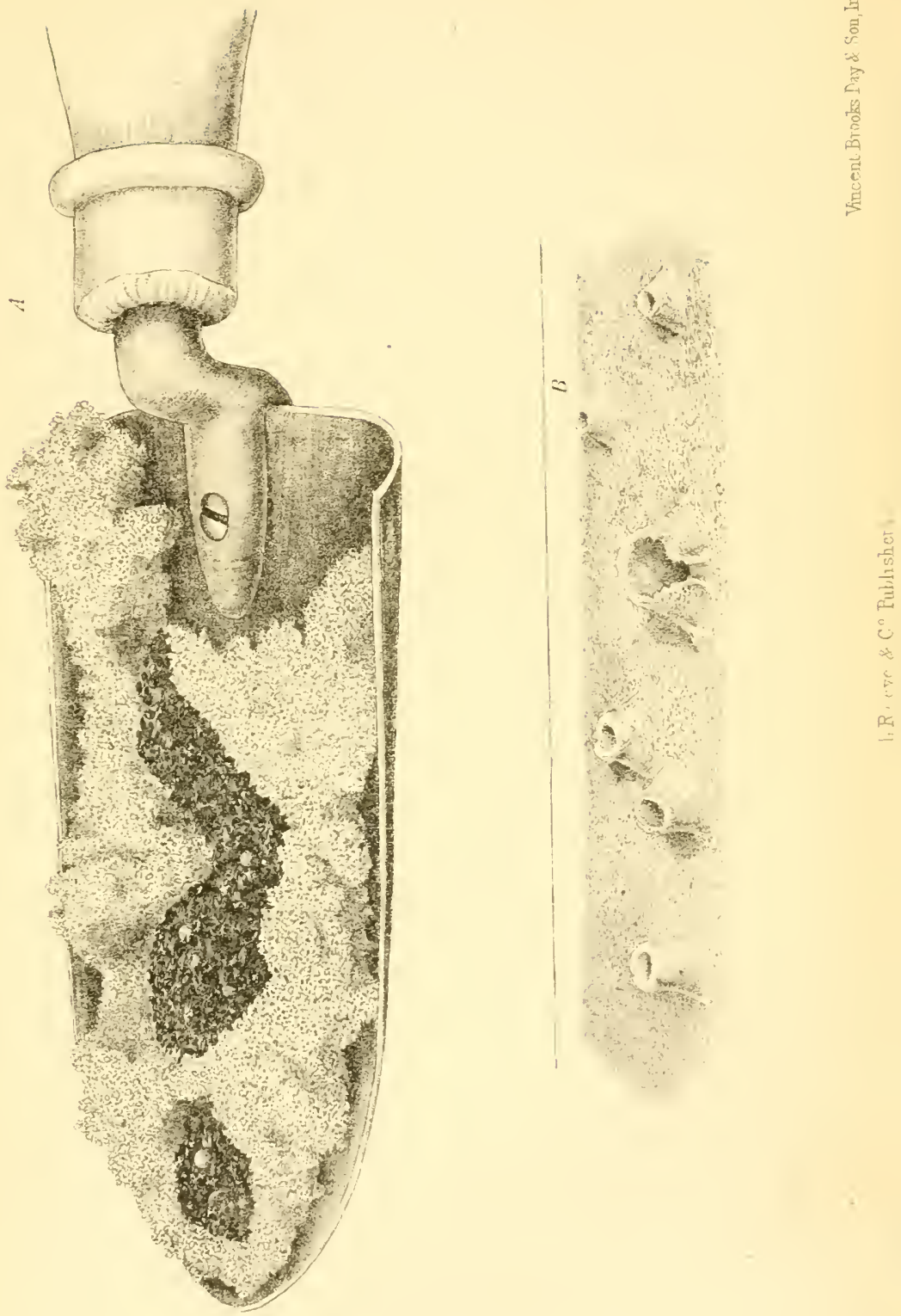



ful of earth taken from this nest, and lifted with care so as to leave the seeds almost in situ. Others were massed together in horizontal chambers, having a concave roof and a flat and carefully prepared floor.

The texture of the floor usually differs markedly from that of the surrounding soil, and the fine grains of silex and mica which are selected for its construction are more or less cemented together, so that the floor will sometimes part, when dry, from the soil about it, as caked and dry mud separates from a gravel path (see Plate III.).

On carefully examining a quantity of the seeds, grain, and minute dry fruits taken from the granaries, I found that they had been gathered from the following plants: fumitory (Fumaria Camreolata, \&c.), amaranth (Amaranthus Blitum, \&c.), Setaria, and three other species of grasses, honeywort (Alyssum maritimum), Veronica, and from four unrecognised species, one of which was a pea-flower. There were therefore in this nest seeds, \&c., which had been taken from more than twelve distinct species of plants, belonging to at least seven separate families. The granaries lay from an inch and a half to six inches below the surface and were all horizontal. They were of various sizes and shapes, the average granary being about as large as a gentleman's gold watch.

I was greatly surprised to find that the seeds, though quite moist, showed no trace of germination, and this was the more astonishing as the self-sown seeds of the same kinds as those detected here, such as fumitory for instance, were then coming up abundantly in gardens and on terraces. The seeds of Odontites lutea afford a curious test of the presence of 
moisture in the granaries, and it will usually be found that, when they are recently taken out of the nest, they are of a greenish colour and semi-transparent hornlike texture, which changes on exposure to the air to a chalky white and opaque appearance, due to the drying of the coat of the seed.

'The fact of the sound condition of the seeds in these granaries seemed to me so very strange and difficult to explain that I determined to pay special attention to the subject, and with this view collected and carefully examined large quantities of the grain and seeds taken at different times from the stores of twenty-one distinct nests, the first of which was opened on October 29th, and the last on May 5th. In these twenty-one nests out of the thousands of seeds taken I only found twenty-seven in seven nests which showed trace of germination, and of these eleven had been mutilated in such a way as to arrest their growth. The sprouting seeds were found in the months from November to February, while in the nests opened in October, Mareh, April, and May, no sprouted seeds were discovered, though these latter months are certainly highly favourable to germination. It is therefore extremely rare to find other than sound and intact seeds in the granaries, and we must conclude that the ants exereise some mysterious power over them which checks the tendency to germinate.

Apparently it is not that moisture or warmth or the influence of atmospheric air is denied to the seeds, for we find them in damp soil, in genial weather, and often at but a trifling distance below the surface of the ground; and I have proved that the vitality of the seeds is not affected by raising crops of young. 
plants, such as fumitory, pellitory, Polygonum aviculare, and grasses, from seeds taken out of granaries.* I have frequently remarked that it is the seeds last collected before a fall of rain which are brought out in a sprouting condition from the nest; for $\mathrm{I}$ have observed in cases where I had recently scattered seeds near wild nests, that it is these which are carried out from the nest and placed to dry after a wet night; and so in the case of a nest which I kept in captivity, when a variety of different seeds had been successively supplied to the ants, it was the cabbage, lettuce, and chicory seeds, given the day before the nest was watered, that reappeared after having been carried below, and not the hemp, cauary, and mixed seeds of wild plants previously strewed on the nest. It seems possible that the process, whatever it maly be, to which the ants subject the seeds which are to remain dormant may require some time, and the construction of the grianary chambers is doubtless a long affair, so that when unusually large supplies of grain, \&c., are brought in by the workers some part of them may not find the necessary accommodation and attention. When the seeds do germinate in the nests, and it is my belief that they are usually softened and made to sprout before they are consumed by the ants, it is very curious to see how the growth is checked in its earliest stage, and how, after the radicle or fibril-the first growing

* This experiment was tried by me on two occasions, in the formcr case the seeds were taken from a granary about four inches below the surface of the ground, on November 10th, and sowed two days afterwards, and several of these were up on Dec. 1st. The second trial was made on seeds found at only onc and a half inch below the surface, on Dec. 29 th, 1871 ; these were sowed in England on June 18th, 1872, and the young plants made their a pearance in large numbers ten days afterwards. 
root of dicotyledonous and monocotyledonous seedshas been gnawed off, they are brought out from the nest and placed in the sun to dry, and then, after a sufficient exposure, carried below into the nest.

The seeds are thus in effect malted, the starch being changed into sugar, and I have myself witnessed the avidity with which the contents of seeds thus treated are devoured by the ints.

Figs. A, B, C, in Plate VI.,p. 35, illustrate the manner in which the ants mutilate the germinating seeds and check their growth. 'Thus, at Fig. C 2 of Plate VI. a sprouting but uninjured canary seed (Phalaris canariensis) is drawn, magnified, and at Figs. C and C I the same of the natural size and magnified, after the ants have gnawed its fibril (fib.), which in this case pierces the undeveloped radicle (rad.). Fig. A 2 represents a sprouting hemp-seed, magnified,* and Figs. A, A l, the same of the natural size and magnified, mutilated, the tip of the radicle being removed.

At Figs. B, B 1, B 2, the same process is shown in the case of a small wild pea.

It is, however, certain that though a few individual seeds may sprout in the nests from time to time either with or without the concurrence of the ants, the great mass remain for mauy weeks, or even months, quite intact, neither decaying nor germinating, whereas every one knows that if a quantity of seeds are placed in the soil in a moist and warm place, all the seeds that are of one kind will almost simultaneously begin to grow after the lapse of a fixed interval.

Now if this took place in an ant's nest, the provisions

* Properly a nut, for it comprises the sced and the enveloping coat of the ovary. The canary seed also, spoken of abore, is a grain containing a seed. 
would have to be rapidly consumed at stated periods and to be frequently renewed; but this is not the case. This is easily shown by an examination of the seeds contained in the nests in April or May, many of which will prove to belong to plants which fruit in the autumn and are not to be found later than November. Thus, for example, on May 5th at Cannes, I discovered nutlets of Cynoglossum pictum, which can scarcely have been collected later than the preceding October or November. Besides, during the time from the middle of January to the middle of March, scarcely a seed is collected under ordinary circumstances, there being extremely few wild plants in fruit at that season, and yet the granaries will be found well filled if a nest is opened at the end of this period.

A knowledge of the fact that ants in warm climates accumulate large and very varied stores of seeds retaining their power of germination, might at times be of service to travellers, by enabling them to obtain, by a stroke or two of the spade, an interesting collection of the seeds and the seed-like fruits of the country, when time and opportunity failed for obtaining them in a more satisfactory manner. The following list of plants, the grain, seeds, and small dry fruits of which I have found in the subterranean granaries of Atla structor and A. barbara, especially the latter, shows that the ants probably collect almost indiscriminately from any fruiting plant that falls in their way.

Fumitory (Fumaria, three species), honeywort (Alyssum marilimum), narrow-leaved sun rose (Fumaria viscida and F. Spachii), Oxalis corniculata, Silene, Linum gallicum, mallow (Lavatera cretica?), medick (Medicago), 
wild lentil (Ervum), spiny broom (Cytisus spinosus), Valerianella carinata, Centrurea aspera, Odontites lutea, Calamintha Nepeta, Polygonum convolvulns and P. aviculare, amaranth (Amaranthus Blitum and palulus), pellitory (Parietaria), Euphorbia, pine (Pinus), wild sarsaparilla (Smilax aspera), Setaria verticillata and S. italica, Andropogon Ischcemem, and of eight other plants of which I do not recognise the seeds. This list, comprising plants belonging to eighteen distinct families, might be greatly prolonged if I were to add to it the names of the seeds which I have seen the ants carry towards their nests, but have not actually detected in the granaries. Thus I have seen trains of ants burdened with the long-beaked, spirally-twisted fruits of crane's bill (Erodium), and, as above mentioned, with capsules of chickweed (Alsine media) and shepherd's-purse (Capsella Bursa pastoris), with whole orange pips, and even haricot beans, seeds of the New Zealand veronica ( $V$. Andersonii), of Silene pseudoatocion, and many other garden plants, also with nutlets of the plane tree and seeds of the cypress.

Pliny mentions* incidentally having watched the ants carrying away cypress seeds, and comments upon the fact that so small a creature should be able to interfere with the growth of such a noble tree.

I have little doubt that the seed stores of the ants in botanic and other gardens, where rare plants are cultivated in southern Europe and in warm climates generally, contain samples taken from the fruits of a great many of the rarer and more interesting species as well as of the weeds and native plants. Indeed I

* Pliny, Nat. Hist., xvii. 14, 3. 
have been told that this is the case by my friend Dr. Bornet, who complains of the depredations committed by the ants in the gardens of the Villa Thuret, at Antibes. They go so far as to plunder the seed bags which are hung from the branches of the trees and shrubs, unless these are securely closed and tied with string; they carry off wholesale the grass and anemone seeds, * which are scattered when the lawns are resown; and Dr. Bornet has seen the seeds of Acacia retinoides lie heaped up by the handful at the entrances of their nests, and disappear below after a few hours.

M. Germain de St. Pierre has observed similar facts at Hyères, where he has detected large stores of cereals in the granaries of the ants, and considers that the robberies committed by these creatures are sufficient in extent to cause a serious loss to cultivators.

It is difficult to estimate the amount of seed stored in a single nest by a colony of ants both on account of the extent of these nests, and because of the number of seeds which are always lost in digging. The nests themselves also vary greatly in size. Perhaps I shall not be very far from the mark however, if I conjecture that average-sized nests contain during the winter months about half a pint of seeds.

Atta structor is more frequently found near houses and in gardens than $A$. barbara, the latter usually living on wild ground adjoining cultivation. There was a flourishing colony of structor in the main street of Mentone, cleverly placed at the lintel of the door of a corn chandler's store, where they were ever on the look out for stray grains of oats and wheat, which

* Properly grass grain and anemone achenes. 
might chance to fall from the sacks. Another nest, in a different part of the town, got its principal subsistence from the grains of canary seed, which were scattered by the birds occupying a cage hanging outside a shop window at a little distance.
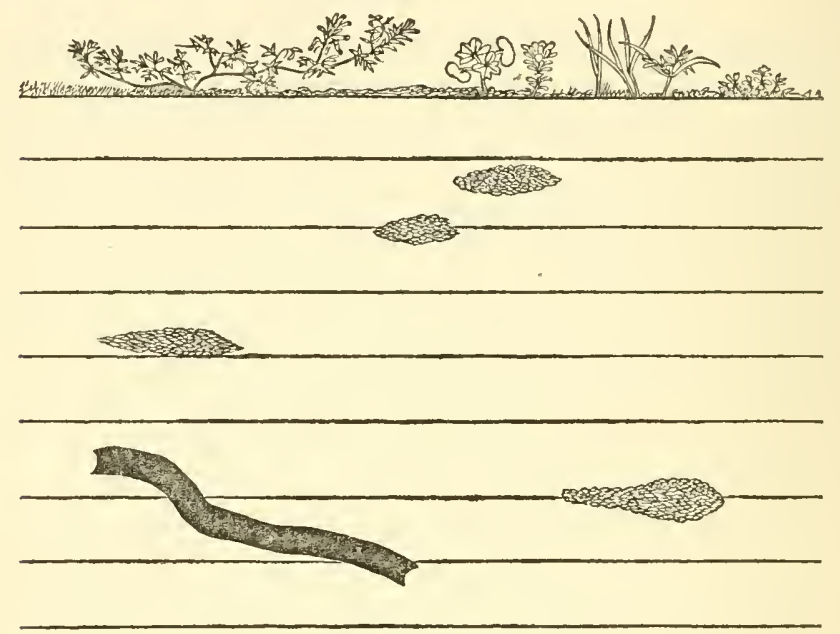

40

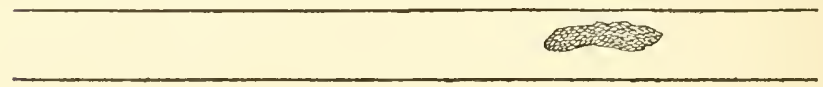

Vertical section of an ant's nest. The horizontal lines represent inches of depth.

The granaries of $A$. structor are arranged in the same way as those of $A$. barbara, and may, in like manner, be 


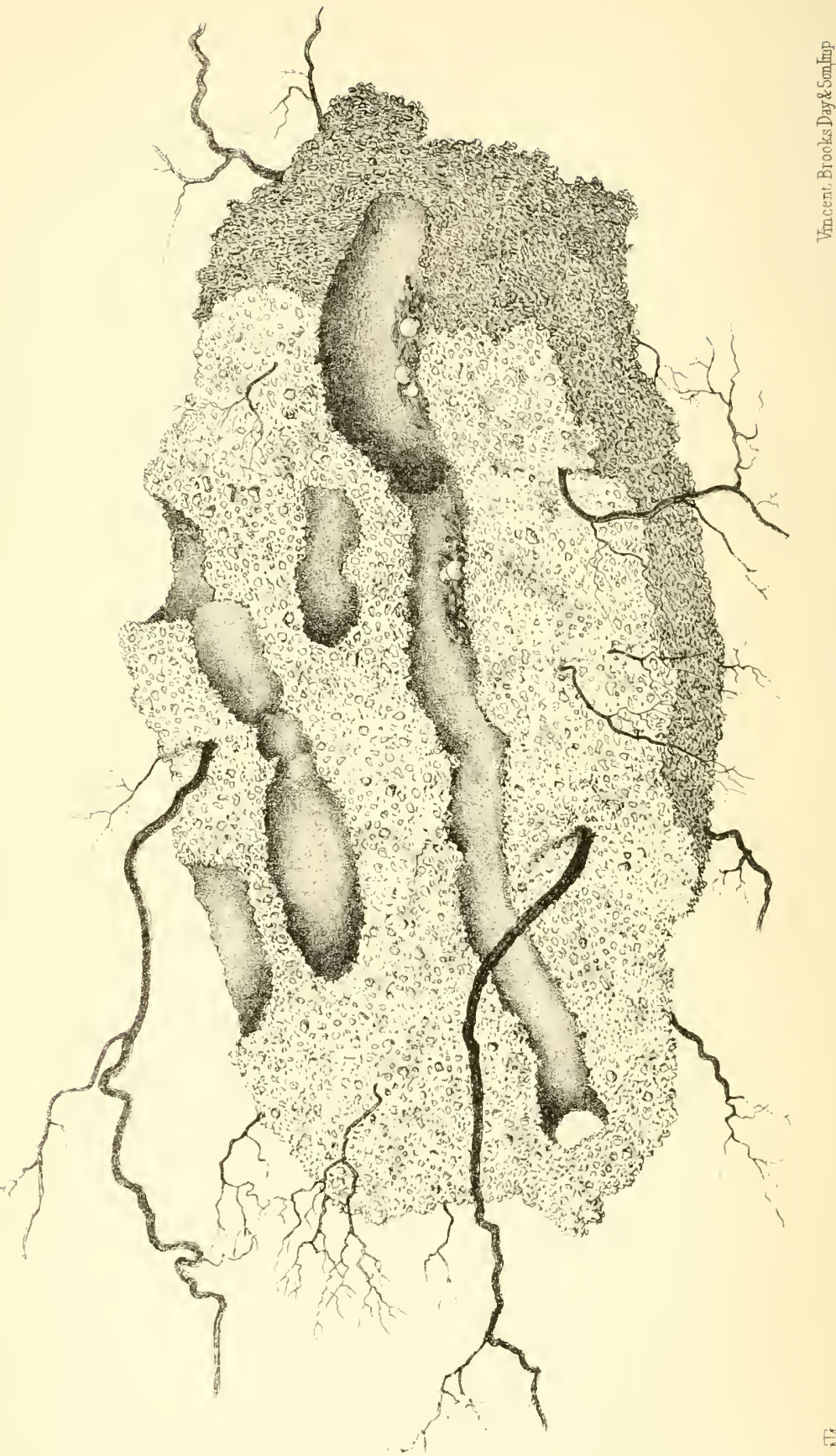
found stored with seeds, and lying at depths below the surface, varying from one to twenty inches.

A diagram is given in the preeding woodcut of a vertical section of a nest of barbara lying in soil sixteen inches deep, the granaries being at $1 \frac{1}{2}, 2,4$, 6,9 , and $12 \frac{1}{2}$ inches, as determined by actual measurement on the spot.

In some cases, and especially where the soil is shallow, the galleries and granaries are much crowded together, as is shown in Plate IV., which represents a small mass of earth, pierced by the roots of plants, taken out of a nest of barbara, lying at two inches below the surface. When first opened all these granaries were filled with seeds.

The shape of the granary chambers varies considerably, as may be seen by reference to the drawing of three floors given in Plate III., p. 23, and that shown diagrammatically in the woodcut on next page, where the white space represents the granary floor, and the dark circular spot in the centre, the aperture of a gallery leading downwards.

I once had an opportunity of seeing a large portion of a nest of the red-headed variety of barbara laid bare by a cutting recently made through a bank at Cannes in digging the foundations of a house, which exposed a very extensive and complicated series of galleries and granaries. The lowest point at which I detected the workings of the ants was at twenty inches below the surface of the ground, and here granaries containing seeds in abundance were present, and the galleries and granaries extended over a space measuring $5 \mathrm{ft}$. 9in. in a horizontal direction. In two cases I have found nests of Alla barbara at Mentone which were carried 
far into the living rock in places where it happened to be of an even grain, and not gritty or pebbly as it frequently is. It was quite by chance that I first discovered this very interesting fact, having tracked a

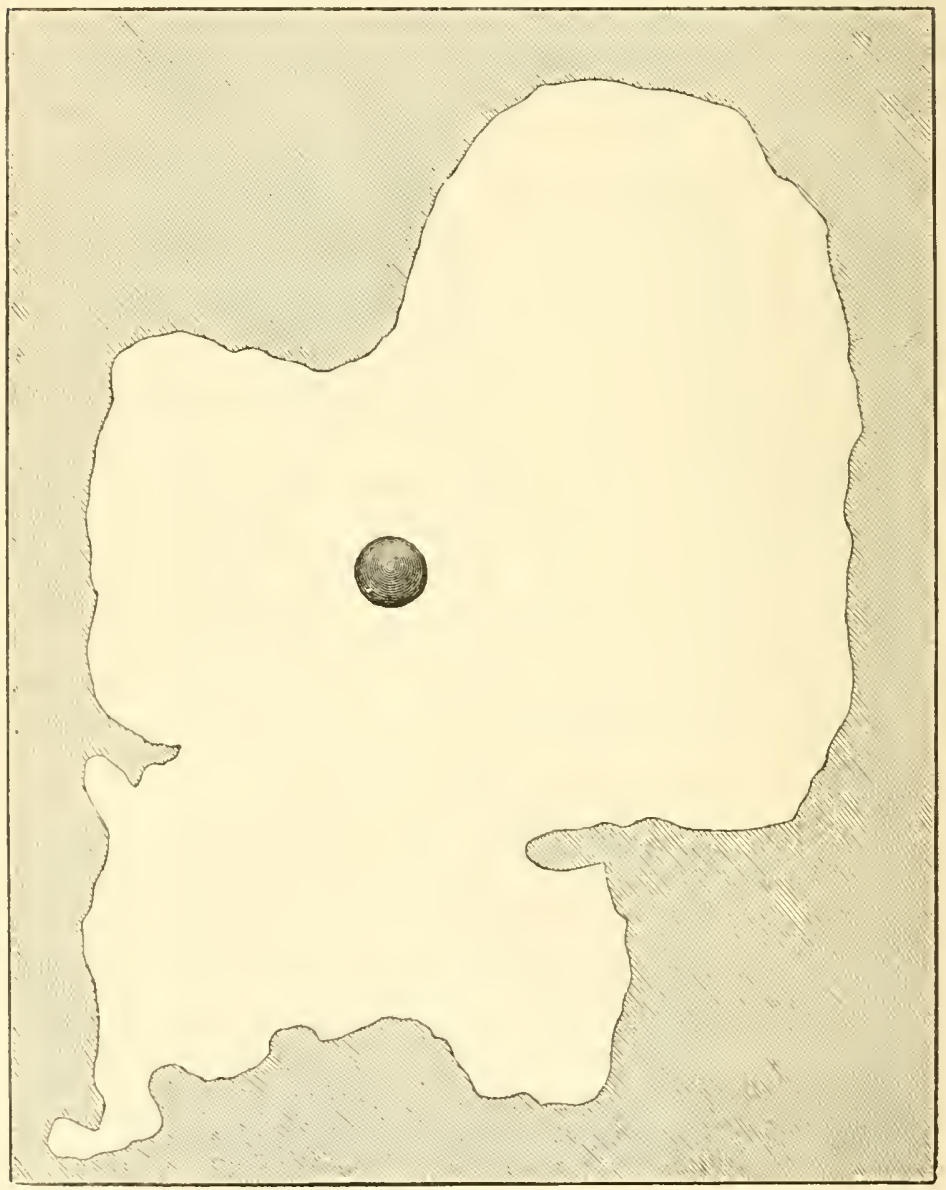

train of seed-bearing workers to a part of the sandstone rock where steps had quite recently been hacked out leading to some terraces. 



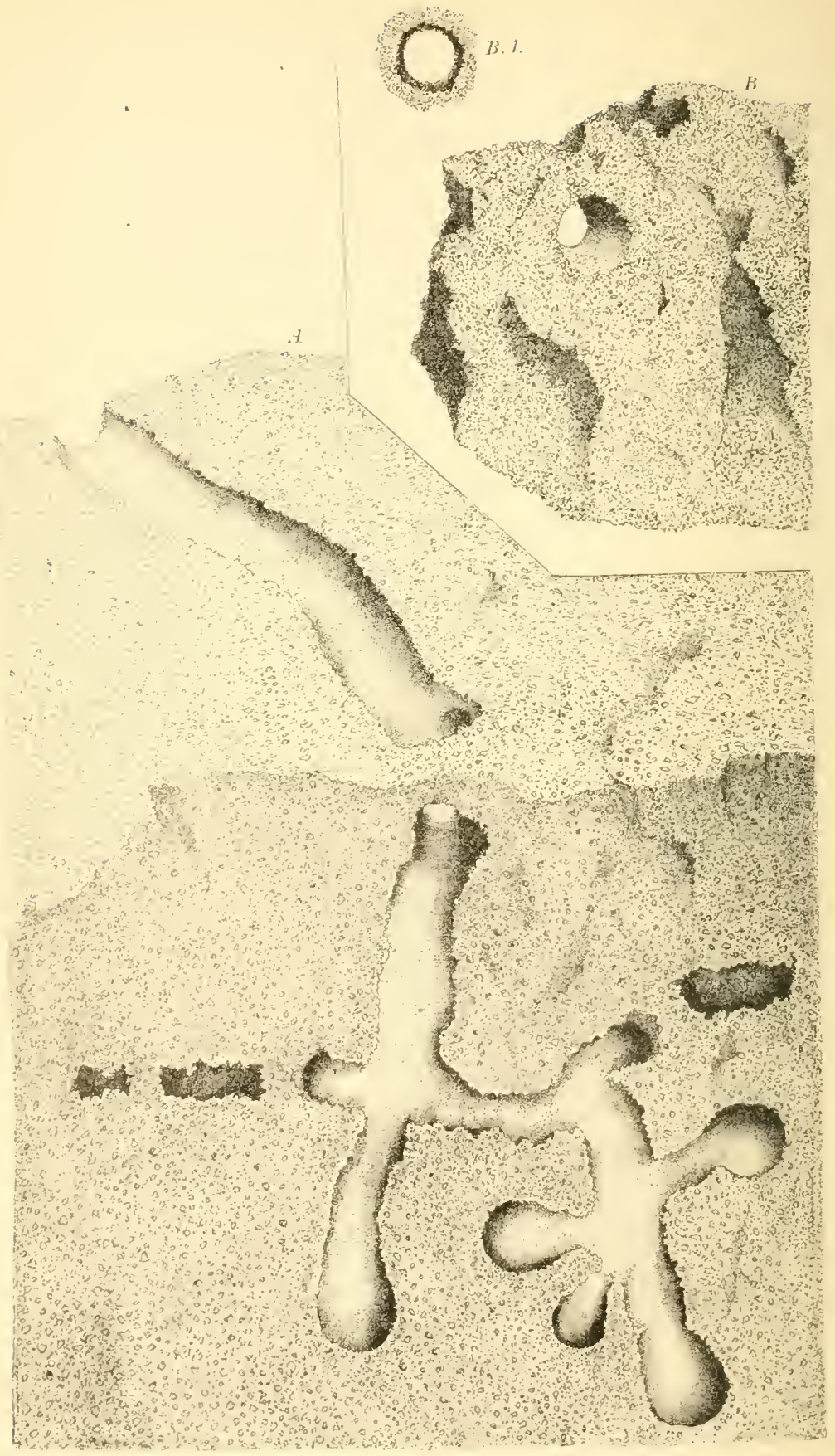

Vincent Brouk. Day \& Son Imp 
I soon saw that the ants entered and came out from three or four small passages in the cleft surface of the rock, and that their nest actually lay in the sandstone itself. Having contrived to wedge off several large flakes of the rock, which was soft in most places and might be scooped out with a strong knife, I discovered that though some of the passages of the ants followed the lines of cleavage and the cracks made by the fine wiry fibres of the bushes growing on the surface, others were frequently made in the form of tubular tunnels through the living rock. Without the aid of hammer and chisel it was not possible to follow the galleries and to secure specimens of the mined rock; but on the next day (Dec. 7th) I returned armed with tools, and with the assistance of a friend * quarried out a portion of the nest, tracing it down eventually to twenty-three inches below the surface of the rock in a vertical, and to about sixteen inches away from the surface in a horizontal direction.

At one point where the rock was almost entirely solid and without flaw or crevice, and where it was clear that the passages were entirely the work of the ants, we measured a tunnel by worming a straw down it, and found it to be ten inches in length. We subsequently traced this tumnel or rock gallery down until it communicated with a chamber filled with winged ants and seeds of several kinds. This granary was horizontal, and merely an enlargement of an ordinary gallery of a compressed spindle-shape, flattened from above downwards, measuring as neariy as I could estimate three inches in length, by a trifle less than

* I take this opportunity of expressing my thauks to $\mathrm{Mr}$. Rohert Iightbocly for help on this and other occasions 
an inch in breadth, and half an inch in height. The walls were tolerably smooth, but not prepared or glazed in the way that certain small terminal cells which I shall shortly describe were. 'The surfaces, however, had a very different appearance to that of the surrounding sandstone, being of a darker and brownish colour, and seeming to be coated with some kind of dressing or cement.

One of these tunnels at first took a horizontal course for two and a half inches, then descended vertically for an inch and a half to a point where it made two horizontal branches, and from these latter several other vertical galleries descended, two of which we were able to trace until they expanded into a cluster of small pearshaped cells, the walls of which were quite smooth and very carefully laid with plates of mica and cement. I was able to draw this on the spot, Fig. A, Plate V., while Mr. Lightbody worked it out piecemeal with hammer and chisel. It was unfortunately impossible to secure more than very imperfect fragments as specimens. These terminal cells were empty when we came to them, but it is quite possible that the ants may have conveyed away larve or winged ants from them, having received abundant notice of the coming danger from the continued jarring of the chisel-work.

One entrance to this nest lay in a small accumulation of soil in a hollow of the rock, and it was at this point that the refuse from the nest was cast out. In- deed, had it not been for the accidental circumstance of my having traced the ants to the newly hewn step in the sandstone, I might never have discovered the fact that the nests are sometimes carried deep into the living rock.

With this to guide me, however, I succeeded in finding a second nest of the same kind, and here I was 


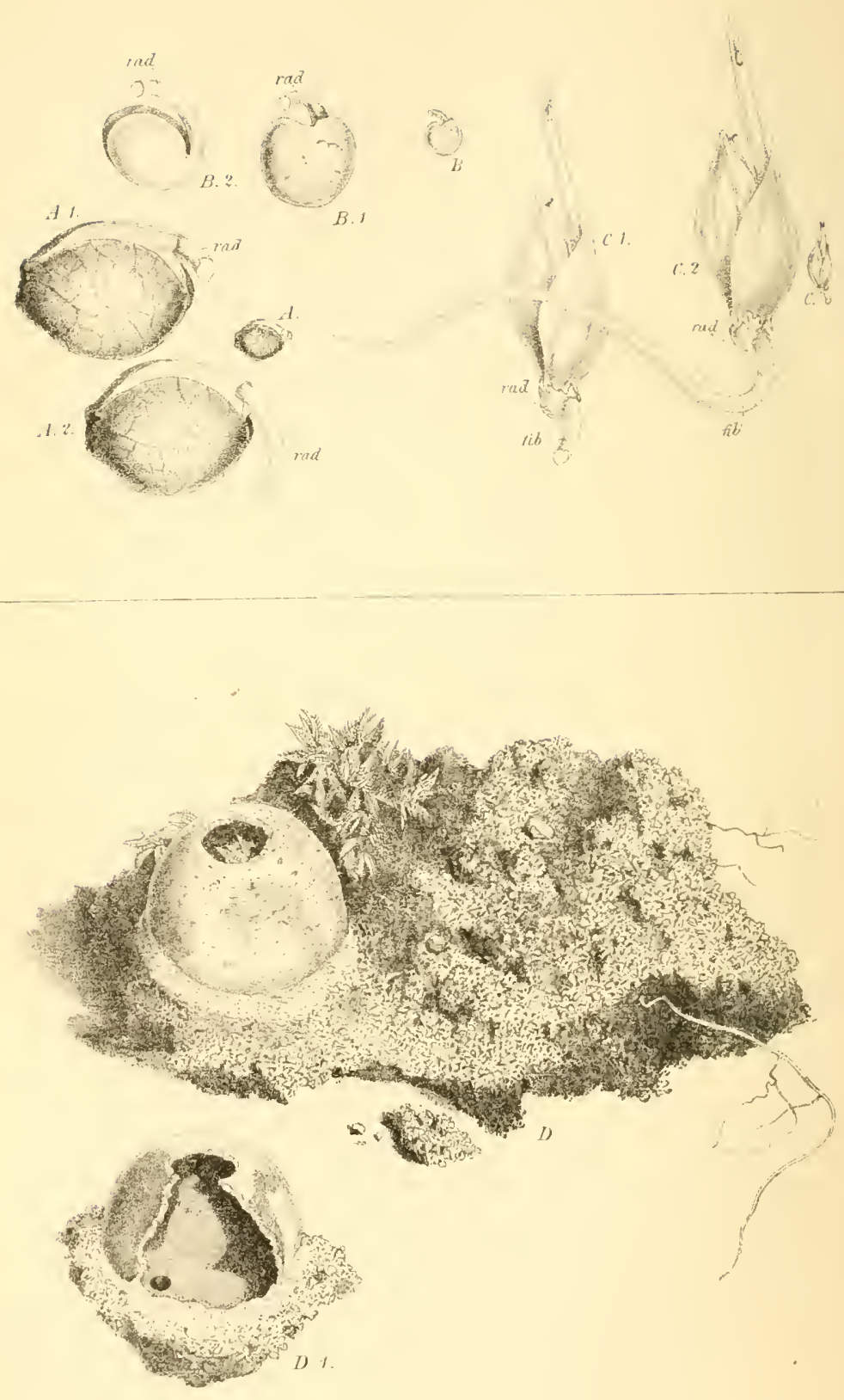
able to secure better specimens of the tunnels for drawing (Figs. B, B 1, Plate V.,p.33). These drawings may be taken as representing also the size and shape of the tunnels in the former nest, which were for the most part like these, beautifully cylindrical, as is shown in the front view of the tunnel at $B$. In one nest of barbara I found a curious hollow spherical dome, about an inch in diameter, the walls of which were constructed of hardened earth about two lines thick, and having a large circular aperture at the top and a rery small one below (Figs. D and D 1, PlateVI.). 'This dome was imbedded below in earth which adhered to it, but it was otherwise easily separable from the soil; its inner walls were smoothed with great nicety.

It has been suggested to me that this spherical chamber was originally the work of a scarabæus, which had chanced to bury the ball containing its eggs close to the nest of the ants, and that the latter had appropriated it after the departure of the beetle grubs. This may perhaps have been the case, but the dome was rather larger than the ball usually formed by the scarab beetle, and I have never seen one of these balls surrounded by a hardened case. The chamber thus constructed was employed as a granary, and filled, as well as the adjacent passages, with the grain of a grass (Tragus racemosus), still enclosed in the husks, among which I detected several ants at work, and also some minute white semi-transparent creatures, like spring-tails (Podurus), which abound in these ants' nests. Besides this spring-tail it is common to find in the galleries and granaries of Atta structor and A. barbara, certain silky yellowish-white "silver fish" ( $L e$ pisma), a small white woodlouse which does not 
roll itself into a ball, and at times the larvæ of an elater beetle. I have observed on more than one occasion that when in digging into an ant's nest I have thrown out an elater larva, the ants would cluster round it and direct it towards some small opening in the soil, which it would quickly enlarge and disappear down. At other times, however, the ants would take no notice of the elater, and it is my belief that the attentions paid to it on former occasions were purely selfish, and that they intended to arail themselves of the tunnel thus made down into the soil, with a view of reopening communications with the galleries and granaries concealed below, the approaches to which had been covered up. I have frequently watched the ants make use of these passages mined by the elater on these occasions.

At one time I suspected that the elater larvæ might consume the seeds stored by the ants, and I therefore confined some of them in a tumblerful of earth and seeds; but at the end of three weeks, though the larvæ were strong and healthy-looking, I could not detect that any of the seeds had been touched, and even those which had sprouted remained uninjured. I have searched in vain for the beetles and staphylinidæe which are known to inhabit certain ant's nests. In one nest I found (on Dec. 28) a quantity of small spherical, egg-like galls, slightly larger than but resembling the fruit of Fumaria capreolata, spotted with pink-brown on a yellowish or greyish ground. There was a dark spot at the point at which the mature insect would emerge, and one did escape from the egg-like cocoon while I was watching, and proved to be a Cynips of very small size, but furnished with a terrible dart for puncturing its prey. 
It seems difficult to understand how it comes that these galls are systematically placed among the seeds, for it was evidently no chance occurrence, and I can only conjecture that the worker ants may have brought them in and stored them under the impression that they were really seeds! Even ants make mistakes, and of this I have given an example above (p. 19). Though I have frequently found colonies of several distinct species of ants inhabiting nests made in the earth traversed by the widespread galleries of Atta structor and barbara, I have never detected any intermixture of species in the chambers of a nest, ${ }^{*}$ and but rarely found even the galleries and entrance used in common by more than one species. On one occasion when opening a nest of structor I cut through a colony of the tiny, large-headed, yellow ant Pheidole megacepluala, lying in the midst of, though distinct from, the former. When, however, it chanced that one of the structors fell from the crumbling earth into the midst of the Pheidoles, it was curious to see how fiercely it would be attacked, and with what terrified speed it would scamper off, without attempting any resistance, and often carrying two or three Pheidoles hanging on to its legs.

Accidentally in this way battles do sometimes take place between ants of different species; but by far the most savage and prolonged contests which I have witnessed were those in which the combatants belong to two diflerent colonies of the same species.

* Except in a few cases where I have seen one or two structors in nests of barbarc and vicevers $\hat{a}$, and in the curious instance to be mentioned below, where one colony consisted of nearly equal parts of structor, barbara, and the red-headed variety of barbara. 
Atta barbara, Formica cruentata, F. erratica, and especially Myrmica caspitum may sometimes be seen fighting in this desperate fashion. Rival colonies of Myrmica caspitum often gather for the battle into dense masses three or four inches deep, and the place of conflict will be seen on the following day strewn with the dead, and this though the majority of the slain are carried off for food by the victors.

But the most singular contests are those which are waged for seeds by $A$. barbara, when one colony plunders the stores of an adjacent nest belonging to the same species, the weaker nest making prolonged though, for the most part, inefficient attempts to recover their property.

In the case of the other species of ant which I have watched fighting, the strife would last but a short time-a few hours or a day-but $A$. barbara will carry on the battle day after day and week after week. I was able to devote a good deal of time to watching the progress of a predatory war of this kind, waged by one nest of barbara against another, and which lasted for forty-six days, from Jan. 18 to March 4 !

I cannot of course declare positively that no cessation of hostilities may have taken place during the time, but I can affirm that whenever I visited the spot, and I did so on twelve diys, or as nearly as possible, twice a week, the scene was one of war and spoliation such as that which I shall now describe.

An active train of ants, nearly resembling an ordinary harvesting train, led from the entrance of one nest to that of another lower down the slope, and fifteen feet distant; but on closer examination it appeared that though tine great mass of seed-bearers 
were travelling towards the upper nest, some few were going in the opposite direction and making for the lower. Besides this, at intervals, combats might be seen taking place, one ant seizing the free end of a seed carried by another, and endeavouring to wrench it away, and then frequently, as neither would let go, the stronger ant would drag seed and opponent towards its nest. At times other ants would interfere and seize one of the combatants and endeavour to drag it away, this often resulting in terrible mutilations, and especially in the loss of the abdomen, which would be torn off while the jaws of the victim retained their indomitable bull-dog grip upon the seed. Then the victor might be seen dragging away his prize, while its adversary, though now little more than a head and legs, offered a vigorous though of course ineffectual resistance. I frequently observed that the ants during these conflicts would endeavour to seize one another's antennx, and that if this were effected, the ant thus assaulted would instantly release his hold, whether of seed or adversary, and appear utterly discomfited. No doubt the antennæ are their most sensitive parts, and injuries inflicted on these organs cause the greatest pain.

It was not until I had watched this scene for some days that $I$ apprehended its true meaning, and discovered that the ants of the upper nest were robbing the granaries of the lower, while the latter tried to recover the stolen seeds both by fighting for them and by stealing seeds in their turn from the nest of their oppressors. The thieves, however, were evidently the stronger, and streams of ants laden with seeds arrived safely at the upper nest, while close observation showed that very few seeds were succcssfully 
carried on the reverse journey into the lower and plundered nest.

Thus when I fixed my attention on one of these robbed ants surreptitiously making its exit with the seed from the thieves' nest, and having overcome the opposition and dangers met with on its way, reaching after a journey which took six minutes to accomplish, the entrance to its own home, I saw that it was violently deprived of its burden by a guard of ants stationed there apparently for the purpose, one of whom instantly started off and carried the seed all the way back again to the upper nest.

This I saw repeated several times.

After March 4 I never saw any acts of hostility between these nests, though the robbed nest was not abandoned. In another case of the same kind, however, where the struggle lasted thirty-one days, the robbed nest was at length completely abandoned, and on opening it I fuund all the gramaries empty with one single exception, and this one was pierced by the matted roots of grasses and other plants, and must therefore have been long neglected by the ants. Strangely enough, not one of the seeds in this de. serted granary showed traces of germination.

No doubt some very pressing need is the cause of these systematic raids in search of accumulations of seeds, and there can be little doubt that the requirements of distinct colonies of ants of the same species are often different even at the same season and date. Thus these warring colonies of ants were active on many days when the majority of the nests were completely closed; and I have even seen these robbers staggering along, enfeebled by the cold, and in wind and rain, when all other ants were safe below ground. 
It may be that unusual exertions are necessitated by some exceptional demands made by the condition of the larræ of the winged male and female ants, and $I$ have observed that these latter appear at very various periods. Thus $I$ have seen winged males and females in the nests of barbara on Norember 10, December 6, February 2 , and Warch 10 ; and in those of structor on February 23, 29, Mareh 1:3, and April 6.

Though structor and burbara make seed collecting the business of their lives, they will, at least in times of scareity, eagerly devour animal food if it happen to fall in their way, and in the harvesting trains a few ants may occasionally be seen carrying small dead insects and the like. Once I threw a dead grasshopper down close to a nest of barbara; it was immediately seized upon, and-after strenuous efforts had been made to dismember it above ground, some ants straining back the legs and wings, while others rushed in to gnaw at the muscles where the tension was greatest, carried down below. On the following morning the wings of the grasshopper were to be seen on the rubbish heap in front of the nest. Dead house-flies and the larve of bees or wasps were at times readily devoured by my captive ants (barbara). I have also seen large numbers of structors engaged in picking the bones of a dead lizard, and was once a witness of the following singular contest between a soft-bodied, smooth, greyish caterpillar, exactly an inch in length, and two medium-sized barbara ants. The ants were mere pigmies in comparison of their prey, for as such I believe they regarded the caterpillar, but they gripped its soft body with set mandibles, showing the most savage determination not to loose their holà.

When I first detected the group the war was being 
waged in a tuft of grass over one of the entrances to the ants' nest, and the caterpillar was striding along the leaves, or thrusting itself between the culms in the hope to sluake off or brush away its little persecutors. From time to time the caterpillar would turn viciously round and endeavour to pluck away its assailants, but though it actually succeeded in stripping off by means of its forelegs and mouth five of the six legs of one of the ants which was within its reach, they never once released their hold.

At length a chance movement of mine shook the grass leaf on which they were, and ants and caterpillar rolled together down a steep and rocky slope to about four feet distant. They tumbled over and over several times, but still the ants gripped their prey as firmly as ever.

The last endeavour of the giant victim was to rub off the ants by burrowing into the soil, but on uncovering its retreat, I saw that their positions were still the same. After watching this struggle for twenty minutes, time failed me, and I returned home, carrying with me, however, the combatants; and when on my return I opened the box in which they were imprisoned, these bull-dog ants were clinging with mandibles locked as firmly as ever, and now as I write, in death they are clinging still, drowned in a sea of spirits of wine.

During the winter and spring I kept two colonies of barbara captive in the house, placed in separate glass jars, each of which might perhaps hold half a gallon. 'The former of these colonies was taken on December 1S; but neither the queen ant nor larva were found, though there probably were larva in some 
unexplored part of the nest, and the ants were alivays restless and miserable, unceasingly trying to escape, and dying in large numbers.

On February 12 I found that all these ants, though abundantly supplied with seeds and all other kinds of food, were dead. Two other colonies of ants, however, which lad been taken in a torpid state in the masses of earth which formed part of the original nest, were alive and well, though still torpid.

The second captive colony, taken on December 28, with the wingless queen ant and quantities of larve, formed a strong contrast with the previous one. Here the ants at once set to work upon the construction of galleries and safety places for the larva below the even surface of garden mould on which I had placed them within the jar; for in this case I did not attempt to preserve any portion of their own nest. This was done at 3.30 r.u., and by 9 that evening I found the ants most busily at work, having in less than six hours excavated eight deep orifices leading to galleries below, and surrounded these orifices by crater-like heaps, made of the earth pellets which they had thrown out. I have observed somewhat similar structures raised by barbara after the nests have been closed on account of rain, and structor frequently raises still more elaborate and distinct craters, such as those represented at Fig. B, Plate II., p. $2: 2$ (reduced one-halt).

On the following morning the openings were ten in number, and the greatly increased heaps of excavated earth showed that they must probably have been at work all night. The amount of work done in this short time was truly surprising, for it must 
be remembered that, eighteen hours before, the earth presented a perfectly level surface, and the larve and ants, now housed below, found themselves prisoners in a strange place, bounded by glass walls, and with no exit possible.

It seems to me that the ants displayed extraordinary intelligence in having thus at a moment's notice derised a plan by which the superabundant number of workers could be employed at one time without coming in one another's way. The soil contained in the jar was of course less than a tenth part of that comprised within the limits of an ordinary nest, while the number of worker's was probably more than a third of the total number belonging to the colony. If therefore but one or two entrances had been pierced in the soil, the workers would have been for ever running against one another, and a great number could never have got below to help in the all-important tack of preparing passages and chambers for the accommodation of the larve. These numerous and funnel-shaped entrances admitted of the simultaneous descent and ascent of large numbers of ants, and the work progressed with proportionate rapidity. After a few days only three entrances, and eventually only one remained open. Yet for weeks this active work went on, and the ants brought up such quantities of earth from below that it became dificult to prevent them from choking up the bottle containing their water, which they repeatedly buried up to the neck. On January 10 the surface of the earth was raised from an inch and a half at its lowest, to three inches at its highest point above its original level, and this bulk of excavated earth 
represented the amount of space contained in their galleries and chambers constructed below. It was not, howerer, until nineteen days after their capture that the ants began to form systematic trains to carry down the seeds which I placed for them on the surface, and I suppose that they had required this time for the construction and consolidation of the granary chambers. From this time forward the ants came out repeatedly in greater or less force to gather in the various seeds with which I supplied them. Indeed, throughout the whole of their captivity they seemed to be perfectly contented with their lot and free from disease, remarkably few ants dying or appearing feeble, and as far as the limited space would permit they reproduced most of the habits which I had noted as belonging to them in a wild state, such as the formation of a rubbish heap; bringing out refuse materials, gnawed and empty seed-coats, the ends of radicles, and root fibres which had penetrated their nest, and laying sprouted seeds in the air to dry after having gnawed off the radicle in order to arrest their growtl.

I was also in this way able to see for myself much that I otherwise could not have seen. 'Thus I was able to watch the operation of removing roots which had pierced through their galleries, belonging to seedling plants growing on the surface, and which was performed by two ants, one pulling at the free end of the root, and the other gnawing at its fibres where the strain was greatest, until at length it gave way. Again the habit of throwing sick and apparently dead ants into the water, the object of which was in part, I imagine, to be rid of them, and partly 
perhaps with a view to effecting a possible cure, for I have seen one ant carry another down the twig which formed their path to the surface of the water, and, after dipping it in for a minute, carry it laboriously up again, and lay it in the sun to dry and recover; thirdly, the stripping off the ccats and husks of seed and grain swelling and on the point of sprouting, previous to eating it; and finally, the actual eating of the contents of the seed.

Most of these operations are usually performed below ground, and even in my captive nest it was but rarely that I could get a glimpse of their subterranean life, as they avoided the glass as much as possible, though it was carefully covered with flannel and black paper; and it was only by having the nest constantly before me on my table, and thus becoming a witness of their operations day and night during four months, that I detected them in positions which permitted me to watch these actions of theirs.

'The ants were in the habit of coming out in numbers of an evening to enjoy the warmth and light of my lamp, and it was on one of these occasions that I first observed them in the act of eating. I perceived that in the midst of the black mass of ants gathered together on the side of the glass jar one was holding up a white roundish mass about as big as a large pin's head. Having turned a stream of bright light passed through a condenser on this group, and being permitted by the ants to make free use of my pocket lens, I was able to see the details with great precision. The white mass appeared to be the floury portion of a grain of millet, and I could see that two or three ants at a time would scrape off minute particles with their 
toothed mandibles, and take them into their mouths, repeating the operation many times, before giving place to other ants, and often returning again. It certainly appeared to be a bona fide meal that they were making, and not merely an act performed for the benefit of the larvæ, as when they detach crumbs from a piece of bread and carry them below into the nest. However, I must own that, though I subsequently dissected ants taken in this act, which I suppose to be that of eating, I was unable by the use of the iodine test to detect starch grains in their stomachs.

Still it seems quite possible that this failure may have been due to my not having allowed the ants sufficient time to swallow their food, as I killed them almost immediately after disturbing them at their meal.

After having twice observed the ants eating as above described, I made some experiments in feeding them myself.

'They immediately seized and set to work upon a minute ball of flour which I cut out from the centre of a grain of millet, taken from a heap in front of a nest of $A$. structor, which had begun to sprout and been deprived of its radicle and dried. A similar ball taken from a sprouting grain of millet, but the growth of which had not been arrested, was also partially eaten; but the hard, dry flour taken from a grain of the same in its natural state, not moistened, was at once rejected and thrown on the rubbish heap. The fat, oily seed leaves of the hemp, however, were eagerly taken, though not softened by water, their peculiar texture allowing the ants to scrape off particles, as in the case of the ball of flour of the sprouted millet. 
Under ordinary circumstances the hard shell of the hemp-seed, and the coats of most other small fruits, grain, and seeds, would prevent the ants from getting at the contents while dry, but in the earliest stage of sprouting the shell parts of itself, allowing the radicle to protrude, and then they find their opportunity. (See Figs. A, A 2, Plate VI., p. 35.)

It has always been supposed that ants, from the delicate nature of their mouth organs, were only able to lap up liquids or to swallow very soft animal tissues, and one of the great difficulties in the way of admitting that they might collect seeds for food, lay in the apparent impossibility of their eating such hard substances. But it has generally been overlooked that not only are all seeds soft when moistened with water and ready to grow, but also that there are certain kinds of seeds the contents of which are naturally soft.

The most important organs in an ant's mouth are shown in Fig. D 2, and D 3, in Plate I.,p.21. D 3 represents one of the horny, toothed mandibles, which serve admirably for scraping off particles of flour from the seeds. Within these are the parts shown at $\mathrm{D} 2$, where the outermost pieces are the maxillæ and their four-jointed palpi or feelers, and the innermost piece the labium and its three-jointed palpi, between which the end of the delicate membranous tongue appears.

I repeatedly placed leaves from the orange trees covered with cocci and aphides from rose-bushes and pine trees, all of which are eagerly sought by several other kinds of ants, in the captive nest, but the ants never looked twice at them, and this corresponds with the fact that I have never seen either structor or 
barbara attending on or searching for aphides and the like. These captives took part of a small quantity of honey which I placed in the nest, but displayed no eagerness about it, and soon neglected and allowed it to be covered up with earth thrown out from the nest.

The ants work very frequently at night during the dark, * and this is the case in the wild as well as in the captive nests. A friend, at my request twice visited a nest of structor ants in the garden of an hotel at Mentone, when it was quite dark (in March, between seven and eight o'clock P.M.) and no moon, but the iight of a candle showed that the workers, both large and small, were busily engaged in carrying into the nest seeds which had been purposely scattered in their neighbourhood. I have myself seen Pleidole megacepluala similarly engaged at about nine P.M. on a warm night in April, when it was perfectly dark, not even the stars showing; but in this case the ants were collecting from the weeds in the garden. On the same occasion I also observed long and active trains of Formica emarginala [a rather small dusky ant, with a yellow thorax], making for the orange-trees in search of cocci and aphides, just as if it were broad day.

Before leaving Mentone, on May 1, I turned out this second captive nest, and found that the colony appeared perfectly healthy, and did not seem to have diminished materially in numbers. The queen ant and the larvæ seemed to be in just the same state as when they were taken. The earth in the lower part of the jar was honeycombed with galleries, granaries,

* This bears out the much-questioned assertion of Aristotle, though he only claimed that ants work "by night when the moon is at the full."-Hist. Anim., lib. ix. cap. xxvi. 
and cells, constructed quite as in the wild nests, but more crowded together. The granaries were in many instances full of seeds, which, though very wet, [the surrounding soil being extremely moist on account of there being no drainage to carry off the water which I was obliged to sprinkle from time to time over the surface of the nest], still showed no trace of germination that I could detect. The ants were therefore able to exercise the same influence over these seeds, under the strange conditions of their captive state, that they do in their natural homes.

The foregoing remarks, as has been stated above, refer for the most part to only one of the three kinds of harvesting ants which I have observed on the Riviera - that is to say, to Atta barbara, the jetblack ant.

As far as the manner of collecting and storing the seed is concerned, all that has been said of Atta barbara applies with equal truth to $A$. structor.

A. structor is, however, less frequently seen above ground from December to March than barbara, and is more frequently found in or near the streets and gardens of a town.

The fourth species, on the other hand, the little Pheidole megacephala, differs in several particulars. This ant appears to shun the daylight, and to be most active at night, when, in the warm weather at the end of April, it may frequently be seen carrying large quantities of seeds into its nest. I have rarely observed it at work in the daylight, so that my knowledge of its habits is but small. Nor have I succeeded in discovering its subterranean granaries, though I have opened several nests. Still, I believe that it is a 
true harvesting ant, and not merely a casual collector of seeds. Of the habits of Pheidole pallidula, a very closely allied and similar species, but one less frequently met with, I cannot speak with certainty, though it is quite possible that it also may be a true harvester, in which case it would add a fifth species to this class.

Both Pleciciole negacepliala and Ph. pallidula appear to remain inactive, or nearly so, during the months from November to April, and it is probable that they are only to be seen in full activity during the summer when I am not there to watch them.

There can be little doubt that any naturalist who will take the pains to note the habits of ants on the shores of the Mediterranean through June, July, August, and September, might collect a most interesting series of observations on harvesting and other species, and add to, and perhaps modify, those which my limited opportunities have enabled me to make.

There are three other ants*-namely, Formica emarginata, F. fusca, and Nyrmica caspitum, which may also occasionally be found carrying a few seeds, but this is the rare exception, as far as my experience goes, these species living on honey dew, sweet secretions, and animal matter, like the great majority of ants all over the world. I have never found seeds in the nests of any ants except those of Atta barbara and A. structor, though I have carefully searched for them in most of the nests of the sixteen species of ants whose habits I have watched.

* For some details of the habits of the sixteen species of ants observed on the Riviera, see Appendix A.

E 2 
There is every probability that these harvesting ants will be found all round the shores of the Mediterranean, but the only points at which I have positively heard of the existence of the habit besides Mentone, Cannes, and Marseilles, are Capri* and Algiers. $\mathrm{I}$ am indebted to Miss Forster for having, during a short visit to Algiers, devoted some time to watching the habits of the ants in a garden at that place. These observations were made in April last (1572), when the three following species were watched:-

(1) Formica (Cataglyphis) viatica, a large, long-legged, blackish ant, with orange-red and semi-transparent thorax, which never carried seeds, but lived on animal food, especially flies. (2) Formica (T'apinoma) nigerrima, $\uparrow$ a rather small dusky ant, which brought in some seeds to its nest, but principally "animal food, flies, small worms," \&c., and which did not carry the hemp and canary seed strewed in their path, though on one occasion when Miss Forster scattered some split hemp seed, they eagerly fastened upon the contents, and ate some on the spot, while they transported the greater part to their nest, and (3) Atta barbara, which, as on the Riviera, was a true and most active harvester, and eagerly seized upon the hemp and canary seed when these were placed in its way.

\section{Recapitulation and Concluding Remarks.}

There are some points of interest suggesting openings for future observation, to which I will now allude,

* Where a harvester, probably Atta barbara, has been observed by Mr. Buchanan White. See Appendix C.

+ Mr. Smith thinks that this ant is either F. nigerrima, of Nylander, or a new species, but it was not possible for him to pronounce with absolute certainty as he had only two speciniens of workers from which to judge. 
making at the same time a partial recapitulation of what has gone before.

We have learned in the first place that the ancients had facts on their side when they said that the ant is one of the very few creatures which lays up supplies of food sufficient to last for months, or even perhaps, as Bochart says, for a whole year; and though we cannot quite accept the statement that "tlere is no animal except men, mice, and ants, that stores its food," "wey were right in saying that the habit is a most singular and interesting one. It is probable, however, that the old writers may have fallen into the error of supposing that all ants were harvesters, though the truth appears to be, that even in hot climates, it is only a very small number of species that are so. The fact that certain ants in Southern Europe do store large quantities of sound seed in dimp soil, and check their tendency to germinate, may be thought to farour the possibility of the existence of those deeply hidden supplies of seed which, though they have never been detected, are popularly supposed to explain the sudden appearance of the crops of weeds on soil newly brought out from great depths.

The argument may be stated thus: seeds remain for months undecayed, and still capable of germination, at depths varying from one to twenty inches below the surface of the soil in certain ants' nests, why should they not lie hidden for indefinite periods in ordinary soil?

To answer this positively, experiments should be

* Soplhian, quoted by Bochart in his Hierozoïcon, ii. cap. xxi. 1. 497. 
made* $^{*}$ in order that we might learn whether these seeds can retain their vitality without sprouting in moist soil ; but the general belief is that under these conditions they will do one of two things, they will either grow or rot. Be this as it may, one of the most curious points that we have learned about these ants, is that they know how to preserve seeds intact, even when within from one to three inches of the surface of the ground, that is to say, at the actual depth at which a gardener most frequently sows his seeds, though if these very seeds are taken out of the granary and sowed by hand, they will germinate in the ordinary way. It is possible that this may be in part due to the compact nature of the floors and ceilings of the granaries, these excluding air in some measure, though as moisture freely passes through them, and there are always two or three open galleries leading into the granaries, and which communicate directly with the open air, I can scarcely accept this explanation as complete.

The seeds do occasionally sprout in the nest, though it is extremely rare to find instances of this, and then the ants nip off the little root, and carry each seed out into the air and sun, exactly as the old writers have described, and when the growth has been checked and the seed malted by exposure, they fetch them in

* In order to try the experiment fairly, seeds taken from ants' nests, or seeds of the same species as those which are babitually found in ants' nests, should be placed at different depths in the earth and examined after the lapse of six or eight months.

Why it is that certain seeds resist the influences which destroy the vitality of other seecls of elosely allied species is another and a very curious but complicated problem, the explanation of which may perhaps lie in the different eheruical properties of the seeds in question, in the more or less permealle character of their seed-coats, or their general texture. 
again. It is in this condition that the ants like best to eat them, as I have proved by experiments among my captives.

As the ants often travel some distance from their nest in search of food, they may certainly be said to be, in a limited sense, agents in the dispersal of seeds, for they not unfrequently drop seeds by the way, which they fail to find again, and also among the refuse matter which forms the kitchen midden in front of their entrances, a few sound seeds are often present, and these in many instances grow up and form a little colony of stranger plants. This presence of seedlings foreign to the wild ground in which the nest is usually placed, is quite a feature where there are old established colonies of Atta barbara, as is shown at Fig. A in Plate 1., p. 21, where young plants of fumitory, chickweed, cranesbill, Arabis Thatiana, \&c., may be seen on or near the rubbish heap.

It would be interesting to make a list of all these ant-imported plants, and I think it quite likely that, if a sufficiently large number of nests were visited, some seedlings of cultivated species might be found amongst them, for we have seen that garden plants are frequently put under contribution.

One can imagine cases in which the ants during the lapse of long periods of time might pass the seeds of plants from colony to colony, until after a journey of many stages, the descendants of the ant-borne seedlings might find themselves transported to places far removed from the original home of their immediate ancestors. It is a true cause, but at the same time it may be one which has, like many true causes, exceedingly small effects. One can scarcely look at the teeming population of an 
ant's nest, without asking whether there are any checks to their increase, and if so, what these cheeks are. I know very little of what foreign enemies they may have, though I have occasionally seen them captured by lizards, Cicindela beetles, and spiders,* and it is well known that the females are eagerly sought for by birds at the season when they are above ground, and about to found new colonies; but I believe that ants are the ants' worst enemies, for fearful slaugh. ter and mutilation often result from the eneounter of armies of the same race, but belonging to different nests.

Harvesting ants have nothing to do, as far as I have been able to discover, with aphides, cocei, and the like, nor do they seek for any of those sweet secretions which are the staple food of the generality of ants; they live, however, on very friendly terms with certain yellowish-white and satiny-coated "silver-fish" (Lepisma), which are found in the passages and chambers of the nests; but what their relations are to these creatures and to eertain beetles which have been found in the nests of Atta barbara in Spain and Syria is unknown. It is possible that by earefully watehing eaptive ants in company with these ereatures under very farourable conditions, something further might be learned on this head. My eaptive ants constructed all their

* I have seen the remains of ants at the bottom of the tube of trap-door spider nests, and watched a hunting spider, Lycosce, capture a large black ant (Formica pubescens), by entangling it in threads, which it deftly spoun about its limbs, while runuing rapidly round the struggling victim in a circle, and dodging out of the way of the ant's mandibles. In England one may frequently see ants canght in the spiders' webs among the rose. bushes, and Mr. Blackwall says, in his Spiders of Great Britain and Treland, that Theridion riparium lives principally on ants. 
chambers, granaries, and almost all their galleries away from the glass, and in the interior of the earth, though I tried to tempt them to work in parts more accessible to sight by swathing the jar in flannel.

There is much to be learned, I do not doubt, about the friends and enemies of harvesting ants; and another great desideratum is further information as to the parts of the world in which they are found and what causes may be assigned for the limitation of the babit.

What is the geographical distribution of the harvesting species, and what the geographical distribution. of the habit? For instance, to quote Mr. F. Smith, * Atta structor, though not "found in England, is scattered over a great part of Europe, having occurred in France, Italy, Germany, Austria, Dalmatia, and Switzerland; it has also been found in Algeria" and Syria ; and $A$. barbara is almost as widely spread. Nay we then conclude that these species are harvesters wherever they are found, and that they store seed in Germany and Switzerland as freely as they do on the shores of the Mediterranean? If this be really so, then Huber, whose attention was specially directed to this point, and a host of laborious and scrupulous observers of the Continent, have had the very fact under their eyes, though they have been at considerable pains expressly to deny it. I camnot think that this is likely, but it is a matter which could easily be settled by those who travel or reside in Germany, Northern France, or Switzerland.

It seems to me more probable, however, that they do store in the south, but not in the north; for all the

* Mr. E. Smith, On Some New Species of Ants from the Holy Land, in Jouru. Limean Soc., London, vol, vi. p. 35. 
difficulties which attend the preservation of the seed in the granaries in the south would be greatly increased in the wet climates of Northern Europe, and there, moreover, the greater cold would render the ants torpid almost throughout the winter, when food would not be required. But the question is plainly an open one. We may also ask why it is that only a very few out of the many species of ants which inhabit the shores of the Mediterranean should possess this habit of collecting seeds, and differ so widely in their manuer of living, from their neighbours?

If we wish to put ourselves in the way to answer these queries, the first thing we should do would be to examine and compare the structure of the digestive organs and parts of the mouth in harvesters and nonharvesters, with a view to seeing whether there may not be some capital difference liere.

These observations demand some skill in dissection and preparation, and in regretting that it has not been in my power to make them, I can only hope that some one more skilled than I am may undertake the subject.

It seems probable, that in warmer latitudes there are many conditions which favour the rapid increase of ants, so that a given tract of country in Southern Europe, for example, must have on an average more colonies to support than a similar tract in the north, and that to meet this increase of population, it has therefore become necessary for these creatures to seek their subsistence from as many and as dissimilar sources as possible. The fierce conflicts over booty both between rival nests of the same and 
of distinct species, tend to show that, even as things are, they frequently have to fight for their food.

Hitherto, as far as I have been able to learn, only nineteen true harvesting ants have been detected in the whole world, limiting this term to those species which make the collection of seeds the principal occupation of their outdoor lives, and are evidently in the main dependent upon this kind of food for subsistence.

Now if we compare these nineteen species of ants* together a very curious fact forces itself upon our notice-namely, that all of them are closely related, so much so that not only do all belong to the same division of ants (the tribe Myrmicinee), but that with one exception (Pseudomyrma) all would have been placed by the great Fabricius in one genus, Atta, and the one exception is not far remored from it.

We must not forget, however, that, as has been stated, there are other ants which do occasionally collect seeds, and thus appear to show traces of this remarkable instinct; but as far as I have yet seen, it is always possible to distinguish them readily from true harvesters. Still I think it very likely that in hot climates the division between harvesters and nonharvesters may be bridged over by a complete chain of intermediates. Here two more questions suggest themselves for more complete future solution. Do true harvesters which store seed in granaries ever

* These are Myrmica (Atta) barbata, from Texas and Mexico; Eco\%oma (Atta) cephalotes, from Brazil and Mexico; Ecodoma (Attu) proxidens, from India ; Ecodoma (Atta) dijus a, from India; Atta rufa, from India; Pheidole (Atta) megacephala, from South France; Atta barbara, from South France, Capri, and Algiers; Atta structor, from South France; and Pscudomyrma rufo nigra, from India. 
attend upon aphides and seek for sweet secretions? (2) Do occasional harvesters ever form granaries?

In any case the name of "the provident one" is only, I suspect, fully deserved by a limited number of ants, and Esop, in his well-known fable, might as properly have made the dialogue which ends in the recommendation to "dance in winter as he piped in summer," take place between two ants as between an ant and a grasshopper, as far at least as their respective foresight is concerned.

Why it is that one ant should require stores of food in the winter of which other ants have no need, is one of the many problems which only patient watching and careful comparison and experiment can help us to solve.

There are not wanting those among the many winter visitors of the south who have time in abundance or superabundance at their disposal, and might help to clear up these and many other mysteries, and to them I would strongly recommend the study of the habits of plants and animals as a pastime, if nothing more.

The way is open : it is not difficult to follow, and it leads to very pleasant places. 


\section{A P P E N D I X.}

\section{A.}

Tre following are the species of ants which I have observed on the Riviera, and principally at Mentone; the actual locality where my notes were taken being given in every case.

\section{Fumily Formicidce**}

Tribe Formicinece.-Petiole (or stalk which unites the thorax and the abdomen) of one joint, and furnished with a single vertical scale, abdomen not contracted.

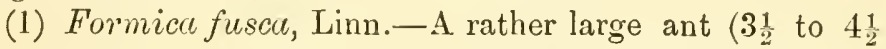
lines long), of a blackish ash colour, with a satiny sheen on the upper half of the abdomen. Sinells of formic acid when crushed. Lives upon sweet secretions and animal matter, and occasionally carries a very few seeds into its nest, which is made in the ground. (Mentone.)

(2) F. emarginata, Latr.-Of medium size (2 $2 \frac{1}{2}$ lines), brownish, with yellow thorax. Has a strong smell of honey when crushed. Lives principally upon sweet secretions, but occasionally carries a very few seeds also. Nest in the ground. (Mentone.)

(3) $F$. (Camponotus) cruentata, Lat.-Large (5 to 6 lines), dusky brown, with orange red on legs and abdomen. Strong smell of formic acid. Lives on sweet secretions and animal

* Ants have been divided into three tribes, the two first of which, Formicinece and Ponerinece, are distinguished by the latter having a contraction in the ablomen not found in the furmer, and both are separated from the third tribe, Myrmicinece by having but a single scale on the petiole, while in Myrmicinece there are always two nodes or protuberances on the petiole. It is important to remember the difference between the first and the last named tribes, as we shall find that all the true harvesters belong to My'micinece. I have not seen any of the representatives of the second tribe in the south. 
matter, and has never been seen by me carrying seeds. Nest in the ground. (Mentone and Cannes.)

(4) $F$. (Camponotus) marginata, Latr.-Large (4 to $5 \frac{1}{2}$ lines), black. Has no perceptible smell even when crushed. Lives principally on sweet secretions, and roes not bring in seeds to its nest, which is made in the ground. I have seen this ant at Cannes ascending the cork oaks in search of certain cocci which resemble black and shining berries rather larger than a pea, and which exude sweet secretions. (Mentone and Cannes.)

(5) Formica cursor, Fonscol.-A rather large but slencler ant ( 3 to 4 lines long), nearly black, with a faint bronzy hue, legs very long. Sinell not noted. Runs very swiftly, and is hard to catch; feeds on sweet secretions, and does not carry seeds. Nest in ground. (Cannes.)

(6) $F$. (species undetermined).-A large ant (5 to $6 \frac{1}{2}$ lines), black brown with yellow thorax and legs. In shape resembles F. marginata. Strong smell of formic acid. Habits not observed. Nest found under a stone in a pine wood. (Cannes.)

(7) $F$. (species undetermined).-A rather large ant (3 to $4 \frac{1}{2}$ lines), resembling $F$. fusca, but having the thorax yellow. Strong smell of formic acid. Feeds on sweet secretions, and does not carry seeds. Nest in ground. (Cannes.)

(8) Formica (Tapinoma) erratica, Latr.-Rather small (2 lines), nearly black. Has a strong and most disagreeable smell, something like rancid oil, which is emitted if the nest is disturbed or the insect crushed. Lives upon sweet secretions and animal matter, but rarely if ever carries seeds, and pajs no attention to them if placed in its path. It nests in the ground, and forms superficial covered ways, roofed in with a thin crust of earth and vegetable fibres cemented together. (Mentone, Cannes.)

Tribe Myrmicinea. Petiole two jointed, furnished with two nodes (protuberances).

(9) Crematogaster (Myrmica) scutellaris, Oliv. - Of medium size ( $3 \frac{1}{2}$ to 4 lines), nearly black, with yellowish red head. Disagreeable smell like rancid oil when crushed. Erects the abdomen when excited, and runs about with it turned up at right angles to the body. Lives on sweet secre- 
tions, and does not carry seeds. When dissecting the abdomen of this ant, I noticed that in freshly killed specimens a drop of poison appears at the extremity of the sting, which if brushed away will form again several times in succession. Nest in the bark and wood of sick or decayed trees. (Mentone and Cannes.)

(10) C. sordidulus, Mayr.-Very small ( $1 \frac{1}{2}$ to 2 lines), resembles $C$. scutellaris, but is uniformly black brown. No perceptible smell. Lives on sweet secretions, and may frequently be seen inside flowers. Nest in earth. Behaves like C. scutellaris when excited. (Mentone and Cannes.)

(11) Myrmica cespitum, Latr.-Small (2 lines), brown. Faint smell like peat smoke. Feeds on animal food and sweet secretions, and may occasionally be seen collecting and carrying in seeds. Nest in the ground. (Mentone and Cannes.)

(12) Pheidole (Atta or Myrmica) megacephala.-Verysmall ( $1 \frac{1}{2}$ to 2 lines), yellow, the larger workers having enormous heads. Smell very peculiar, and a trifle like aniseed when crushed. Appears to be a true harvester, and not to seek for sweet secretions. Nest in ground. (Mentone and Cannes.)

(13) Ph. (Atta or Myrmica) pallidula.-Very small (1 $\frac{1}{2}$ lines), pale yellow, closely resembles $P h$. megacephala, but is paler and more transparent, and the larger workers have less disproportionate heads. Smell not noted. Habits not fully observed. Nest in ground. (Mentone.)

(14) Atta (Aphenogaster or Myrmica) structor.-Rather large ( 2 to 4 lines), of a claret brown. No smell when crushed. A true harvester, and does not appear to seek for sweet secretions, though it will occasionally take animal food. Nest in ground or under stones. (Mentone and Cannes.)

(15) Atte (Aph. or Myrmica) barbara.-Rather large (2 to 4 lines), jet black. No smell when crushed. Habits of strucior. Nest in earth, and more frequently in uncultivated ground. I have twice seen a few ants coloured like structor in colonies of barbarce. (Mentone, Cannes, and Marseilles.)

(16) Atta (Aph. or Myrmica) barbara var.-A large ant (3 to 6 lines). The larger workers black, witl red or mahoganycoloured heads, the smaller most frequently black, and like those of Atta burbara, of which this is probably only a 
variety. It differs however in its smell, which, when the body is crushed, resembles that of Pheidole megacephala, and is something like aniseed. Habits of structor and barbara. Nest in earth. On one occasion I opened a large nest at Cannes, where the colony was composed in about equal parts of ants which in colour and appearance might be said to represent the three forms, structor, barbara, and the redheaded variety of the latter. There were also a few ants with pale yellowish brown heads. (Mentone and Cannes.)

\section{B.}

The following Indian species are described by the late Dr. Jerdon as harvesters, in the Madras Journal Lit. and Sc. $1851:-$

(p. 45). Atta rufa.- "Its favourite food is dead insects and other matter, but it also carries off seeds like the $E_{C O}$ doma, chaff," \&c. \&c. (p. 46). OEcodoma providens._"Their common food I suspect to be animal matter, dead insects, \&c. \&c., which at all events they take readily, but they also carry off large quantities of seeds of various kinds, especially light grass seeds, and more especially garden seeds, as every gardener knows to his cost. They will take off cabbage, celery, radish, carrot, and tomato seeds, and in some gardens, unless the pots in which they are sown be suspended or otherwise protected, the whole of the seeds sown will be removed in one night. I have also had many packets of seeds (especially lettuce) in my room completely emptied before I was aware that the ants had discovered them. I do not know, however, if they eat them or feed their larvæ on them, though for what other purpose they carry them off I cannot divine. I have often observed them bring the seeds outside their holes, as recorded by Colonel Sykes, and this I think generally at the close of the rainy season; but in some cases $\mathrm{J}$. had reason to believe that it was merely the husks, of which I have seen quite heaps, and that the ants did not take them back to their nests. If any of the forementioned seeds be sown out at once in a bed, most likely in the morning the 
surface of the whole spot will be found covered over with little rilges, the works of these creatures, and the few seeds that perhaps remain, dug all round, and being carried off sometimes above ground, at other times under ground. Their galleries and subterranean passages are often very extensive, and it is no easy matter to dig down to their nest to see what becomes of the seeds." Ecodoma diffusa has the same habits as E. providens.

Lieut.-Col. Sykes, Descriptions of New Indian Ants in Trans. Ent. Soc. Lond., i. 103 (1836).

Atta providens, Sykes. "In illustration of the habits of this species of ant, I shall give the following extract from my diary :-_'Poona, June 19, 1829. In my morning walk I observed more than a score of little heaps of grass-seeds (Panicum) in several places on uncultivated land near the parade-ground; each heap contained about a handful. On examination, I found they were raised by the above species of ant, hundreds of which were employed in bringing up the seeds to the surface from a store below; the grain had probably got wet at the setting in of the monsoon, and the ants had taken advantage of the first sunny day to bring it up to dry. The store must have been laid up from the time of the ripening of the grass-seeds in January and February. As I was aware this fact militated against the observations of entomologists in Europe, I was careful not to deceive myself by confounding the seeds of a Panicum with the pupæ of the insect. Each ant was charged with a single seed, but as it was too weighty for many of them, and as the strongest had some difficulty in scaling the perpendicular sides of the cylindrical hole leading to the nest below, many were the falls of the weaker ants with their burdens from near the summit to the bottom. I observed they never relaxed their hold, and with a perseverance affording a useful lesson to humanity, steadily recommenced the ascent after each successive tumble, nor halted in their labour until they had crowned the summit, and lodged their burden on the common heap." "

(p. 104). "On the 13 th of October of the same year, after the closing thunderstorms of the monsoon, I found this species in various places similarly employed as they 
had been in June preceding; one heap contained a double handful of grass-seeds. It is probable that the Atta providens is a field species of ant, as I have not observed it in the houses."

\section{C.}

After the appearance of a brief notice of a communication which I sent in the winter of 1871-72 to the London Entomological Society, announcing the fact that certain ants harvest seeds in a systematic way at Mentone, two papers were pub. lished, in which confirmatory evidence of the existence of the habit in other parts of the world was set forth-one by Mr. Buchanan White, and the other by the late Mr. Horne.

Mr. Horne's account of his observations was published in Harlwicke's Science Gossip, No. 89, p. 109 (for May 1, 1872), and runs as follows:

"My notes carry me to the far East, where I have often watched this most interesting class of insects, and briefly recorded my observations-unfortunately cut short by illness, and the necessity of return to Europe, which must be my apology for their want of completeness.

"But before transcribing, I would remind my general reader that all ants may be seen carrying off food to their nests for present consumption, and that this foord consists of a great variety of substances. This is disposed of inside the said nest, being often masticated, and the juice extracted by the workers, and then given in an inspissated form from their mouths to the young grubs, which are in general tended by their nurses with the greatest care. It is indeed very curious to watch this feeding process; but to proceed.

"Under date Nov. 7th, 1866, I find in my natural history note-book as follows:-Mainpuri. This morning as I was walking across the 'Oosur,' or waste plain, where it was very sandy, being cut into small ravines, and clothed only here and there with fine grass disposed in clumps, thus forming little hillocks of sand blown by the wind, and arrested in its course

* I omit the preliminary portion, in which my observations are erroneously stated to have been made at Nismes and Capri. 
by the grass, I came across a long line of ants, travelling four deep, some coming empty, and others laden each with one grass-seed, on their way home.

"I followed up the procession to the nest, which was subterranean, and at the mouth of which on the level plain there was no trace of elevation caused by the soil brought up from below, owing to the habit of these ants of taking each grain of sand to some distance along their road, and depositing it on one side or the other.

"There may have been five or six entrances to the nest, in and out of which a prodigious number of ants were passing, the species of which has been described by Dr. Jerdon. They were of a medium size, shortish bodies, and of a reddish-brown colour-Pseudomyrma rufo-nigra, Jerdon. Around the mouth of the nest, forming a circle of perhaps eighteen inches in diameter, was a space beaten flat, and kept clear by these said ants, from which radiated in every direction thirteen roads, each about four inches in width for about thirty to forty yards, when they branched off and became narrower, being ultimately lost amongst the grass roots. These paths were fairly straight; they did not cut through elevations, but went round them.

"From a careful examination it appeared that they had been cleared of all obstacles, such as small stones, twigs, \&c., but that their smoothness resulted only from the tread of countless feet.

"The bearers of burdens took the seeds into the nest, which I did not dig up, and certainly stored them there, after having prepared them, probably by the removal of a portion of the outer husk. Of these husks there were large collections near the entrances to the nest, all carefully set aside by the ants.

"In times of famine, I am told, not only are the nests rifled of their grass-seed stores, but these heaps of apparent husks are collected and ground with other grain to eke out a subsistence.

"This kind of grain has a name, 'Jurroon,' derived from 'Jharna,' to sweep, literally sweepings. I much regret that I have not preserved specimens of this 'Jurroon', for it is very unlikely that the ants after taking it to their granary, snould again throw it out, and yet, if grainless, what benefit 
could there be in eating it? The season of the year when I observed them (November) is the beginning of the cold weather, and no rain would probably fall (excepting a little at Christmas) till next May or June. Later on seed would be rare; and how the nest fares at a time when floods of water often pass over the plain I cannot conceive.

"It is clear that some escape, and we know with what prodigious rapidity these colonies increase. But these jottings have been recorded merely to show how this species of ant store grain against a time of scarcity, and fully bear out the statement in the text with which I commenced this paper."

The following are Dr. Buchanan White's notes, alluded to above, published in the Transactions of the Entomological Society (London, 1572) part i., Proceedings, p. v. :-

"Capri, June 3, ]866. In the afternoon to the Punta Tragara, where a colony of ants afforded us much amusement. These little insects had a regular road, made by cutting away the grass and other plants in their way. This road was about one inch and a half wide, and several yards long, and led to a clump of plants in seed. Along this road a long train of ants were perpetually travelling to the nest (or formicarium), bearing with them porls of leguminous plants, seeds of grass and of Composites (Chrysanth. segetum), \&c.

"The perseverance with which a single ant would tug and draw a pod four times his own length was very interesting; sometimes three or four ants would unite in carrying one burdeu. Near the formicarium was a great mass of débris, consisting of empty pods, twigs, emptied snail shells, \&c., cast out by the ants. The seeds appeared to be stored inside the nest, as in one that I opened the other day I found a large collection. The species was a black ant; the formicarium was underground."

D.

\section{On Collecting and Examining Ants.}

There are very few bránches of natural history which might be rnore easily followed by a traveller, or one who fears to 
encumber himself with bulky collections difficult to transport from place to place, than the study of ants. The whole European ant fauna might be adequately represented by specimens preserved in spirit of wine and packed in the compass of a hat-box.

In taking specimens of ants it is important never to put the representatives of more than one nest in each bottle, but then in most cases a sufficient number may be placed in a single bottle of the size used for containing the smaller homcopathic globules. If possible the winged male and female ants, as well as the wingless workers, should be secured.

The ants die very quickly in pure spirit of wine, and they can afterwards, even after the lapse of months or more, be pinned ort in the cabinet after having been washed in warm water. In examining the mouth organs of an ant in order to determine by the aid of books to what genus it belongs, it is best to relax the parts by first washing away the spirit of wine, and then leaving the specimen for a day or more in a stopper bottle partly filled with fuely chopped laurel leaves. It is probable that a drop or two of prussic acid on a bit of sponge might act as effectually in rendering the tissues pliable,

A compound microscope is necessary for the final examination of the joints of the labial and maxillary palpi (see Fig. D 2, Plate I., p. 21); but the neuration of the wing (D 1, Plate I.), another very important character, is easily detected with a good pocket-lens.

The works which may most usefully be consulted are, for France, M. Nylander's Formicides de France et d'Algérie, published in vol. $v$. of the fourth series of the Zoological Division of the Annales des Sciences Naturelles; for England, Mr. F. Smith's Catalogue of Britishe Fossorial Hymenoptera (1556); and for a more general review of the species in the world at large, Mr. F. Smith's Cutalogue of Hymenopterous Insects in the Collection of the British Huseum, Part vi., Formicide (1858), and M. Mlayr's Beiträge zur Kenntniss der Ameisen, published in the Virluandungen des Zoologisch-botanischen Vereines in Wien, iii. 1853. Abhandlungen (p. 10]). 



\section{PART II.}

\section{TRAP-D O R SPIDERS.}





\section{PART II.}

\section{TR A P - D O OR SPIDERS.}

IT is now one hundred and sixteen years since Patrick Browne gave an illustration in his Civil and Natural History of Jamaica* of the nest of a trap-door spider, the first record of the kind with which I am acquainted. Seven years later the careful observations of the Abbe Sauvages appeared, $†$ in which he gave a very good description of the nests of the "araignée maçonne" (Nemesia camentaria), which he discovered near Montpellier, likening them to little rabbit burrows lined with silk and closed by a tightlyfitting moveable door. In 1778 and 1794 Rossi + published an interesting account of the nest and habits of a trap-door spider which he had observed in Corsica and near Pisa; and from that time up to the present day the curious dwellings of these creatures, many species of which have been discovered in warm climates, have continued to attract the attention of naturalists.

Very little, however, has been added to our knowledge of the life-history of these remarkable archi-

* P. 420, tab. 44, fig. 3 a. This work was published in London in 1756 .

† In Histoire de l'Acad. Royale des Sciences (Paris 1763), p. 26-30.

¥ Rossi (P.), Osservazione Insettologische (Memorie di Matematica e Fisica della Società Italiana, vol. iv. (1778), and Fauna Etrusca, vol.ii. (1794). 
tects for several years past, and, indeed, I think it may be safely asserted that the study of the habits and interdependence of the members of the animate world has not, during the last fifty yeirs, made anything like a corresponding progress to that which may be seen in classification and description. The microscope has led many who, a century ago, would have found their chief delight in observing those points in the habits and external characters of living creatures which the naked eye could readily seize upon, to look much closer, to anatomize and describe in detail every organism, great and small, and to examine every tissue and cell.

It is, however, to the materials now being amassed by these modern "cabinet naturalists" that recourse must be had if we wish to form a true comprehension of the functions and habits of living things. They must tell us, for example, what instruments, tactile and visual, an animal possesses if we wish to understand how it constructs a particular fabric, so that the "field naturalist" will have to apply to his brother of the "cabinet" before he can turn his observations to good account.

Still, the fact remains that the habits of plants and animals afford many openings for careful investigation, and such as are especially within the reach of those lovers of nature who have ample time at their disposal, and the opportunity to spend it in a warm climate where life abounds, and is never wholly checked even in the depth of winter. It seems strange to think that collectors so frequently take creatures out of wonderfully constructed nests and yet never observe, or at any rate never describe, the 
structure of these fabrics. Thus, for example, the dwellings of only eight out of the thirty-six species of trap-door spider stated by Prof. Ausserer* to belong to the Mediterranean region are known in books, those of the remaining twenty-eight being, as far as I have been able to learn, yet to be discovered. This is the more strange as from the nocturnal habits of these creatures it is almost always necessary to dig them out of their nests; indeed it is more than probable that if all the dwellings which have been destroyed had been described, the following pages would never have appeared.

Before proceeding to pass briefly in review what has been written on the subject of trap-door spiders, it will be well to take one glance at the relation which these spiders bear to their fellows. The great order of spiders (Aranea) has recentlyt been divided into seven sub-orders, the fourth of which, Territelaria, includes all the trap-door spiders, and some others which do not construct trap-doors. This sub-order corresponds with that which was formerly called Mygalida, but this name, as well as that of Mygale, originally given to all trap-door spiders, has been abandoned because this latter name had previously been applied to a genus of Mammals, and it was feared that confusion might arise.

The Territelaria [or underground weavers] are distinguished from all other spiders by the position of

* Prof.Ausserer (Anton.), Beiträge zur Kenntniss der Arachniden Familie der Territelariæ (Mygalidæ), in Terhandlungen der k.k. Zool. But. Gesellschaft in Wien. Jahrg. 187 1, Band xxi.

+ Thorell, On European Spiders, in Nova Acta Reg. Soc. Scient. Upsaliensis, ser. iii. vol. vii. fasc. 1 and $2(1869.70)$. 
their falces, "which have the fang directed downwards, and move vertically parallel to one another. Thus when a victim is seized by one of the Territelarice it receives a downward blow, while other spiders strike sideways, the falces moving in a horizontal or oblique direction. With very few exceptions this sub-order may also be known by the presence of four blotches of paler colour at the base of the abdomen underneath, indicating the position of four air-sacs, almost all, or indeed perhaps all, other spiders having but two.

Certain species of Territelarice are the only spiders known to construct nests closed with a door, and these creatures must be admitted to rank among the first of Nature's handicraftsmen and inventors.

The geometrical webs of many common spiders are very beautiful structures, but these are for the most part only snares for prey, and not permanent dwellings, although the cocoons in which the eggs are placed are often most ingeniously contrived. Thus in the south we may sometimes find an inverted balloon of strong silk about an inch long attached to heath and other bushes, which, if examined during the winter, will be found to contain in its centre a case enclosing a mass of eggs about one-third the bulk of the entire cocoon. This inner case is shaped cxactly like the outer, and both have a circular silk lid carefully closed, and the space between the two is filled with a dense mass of golden-brown silk, which acts no doubt as an excellent non-conductor. This cocoon is the work of Epeira fasciata, a species apparently only found in southern Europe.

* Sometimes called mandibles. One of these is represented, enlarger, at Fig. A 7. in I'late VII., p. 88. 
Other spiders again, such as Theridion, suspend by a long and delicate cord of silk a minute balloon, scarcely larger than a seed-pearl, containing their eggs, which sways to and fro in the lightest breath of air. But admirable as these cocoons and geometrical snares are, the homes of these and of spiders generally do not exhibit much contrivance or ingenuity, or cannot at any rate be ranked in the same category as those of the trap-door spider. But it may be asked, why should we admire the one more than the other, since it is clear that the most squalid and meanlooking nest exactly serves the purpose of its occupant, whether for shelter or defence, and in many cases a spider might even say with truth that as for her home it would not be so safe if it were not so dirty.

But the answer is simple: the trap-door spider's dwelling is to that of common spiders what the Mont Cenis tunnel is to other tunnels, and something besides.

What delights us is to see how by clever contrivance and great perseverance new and multiplied difficulties have been overeome, and dangers avoided, and the interest aroused is exactly proportionate to the amount of these difficulties and dangers.

It is hoped that the following pages and their accompanying illustrations will vindicate the claims of these spiders to the marked attention and admiration which is here asserted to be their due as architects and engineers.

There is but one British or North European representative of the Territelaria-namely, Atypus piceus (or

* Theridion variegatum (Bl.). Erotuberculata, Koch. 
Sulzeri), ${ }^{*}$ and this creature does not appear to deserve the name of trap-door spider, for in three nests winich M. H. Lucas kindly showed me, preserved at the Jardin des Plantes at Paris, the mouth of the tube was destitute of any covering. I gathered from what I saw, and from what M. Lucas told me, that these nests [which he had taken in the neiglibourhood of Paris], consist of a silk tube from eight to ten inches long, of which about one inch only at the lower extremity penetrates the earth, the remainder being carried upwards in an irregular and sinuous course among the stems and leaves of small plants and grasses to which it is attached. When the tube is removed from these supports it collapses, and appears like a rather coarsely woven ribbon-shaped strip of silk. $\uparrow$

Four types of trap-door nest, properly so called, may now be distinguished in the world at large, and these are represented diagrammatically in the following woodcut. +

* Unless it should prove, as Prof. Ausserer suggests, that the British Atypus is distinct from the Continental, when it would bear the name of Atypus Blachwallii. (Ansserer, 1. c. p. 17).

$+I$ have never been able to meet with an English specimen of the nest of Atypus; but it would appear from the descriptions that the Euglish differ from the French nests in being subterrauean, and in having the mouth of the tube concealed by a loose flap of silk. Mr. Blackwall says : [Spiders of Great Britain and Ireland, part i. p. 14] "Dr. Leech has taken specimens of Atypus Sulzeri in the viciuity of London and Exeter. It excavates, in humid situations, a subterraneous gallery, which is at first borizontal, but iuclines downwards towards its termination. In this gallery it spins a tube of white silk, of a compact texture, about half inch in diameter. ..... Part of the tube hangs outside of the aperture to protect the entrance."

It would be interesting to learn whether these differences permanently distinguish the English from the Freuch nests, and if so, whether the spiders which construct them are not, as Prof. Ausserer is inclined to believe, distinct also.

¥ Where all the tigures, except C 1, and D 1, which are of the natural size, are recluced to about one-third of the actual size in large specimens. 
Of these two only (A and B) were known up to the present time, the construction of which is much simpler than that of the two new types (C and D), which I have hitherto only found at Mentone and Cannes.*

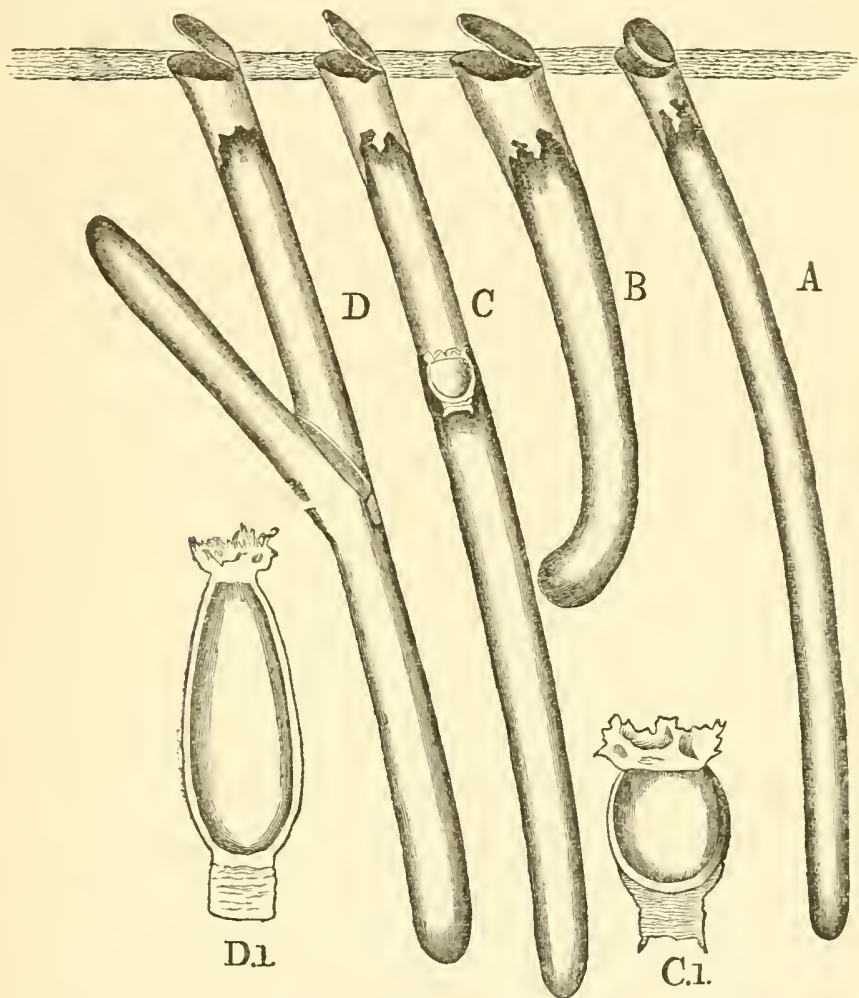

It will be seen at a glance that $\mathrm{A}$ and $\mathrm{B}$ have but

* It must not be supposed that I hare a sole or prior claim to what may prove to be new and of interest in the following observations on the Trapdoor Spiders of the Riviera. This priority belongs to the Hon. Mrs. Richard Boyle, to whom I owe it that I ever took up the subject. It was, thanks to her guidance, that I first became acquainted with these marvellously-concealed nests in their native haunts, and to her active help that I finally arrived at a comprebension of the different types of strueture which they present. 
one door, while $\mathrm{C}$ and $\mathrm{D}$ have two, these latter having a surface door, and also another door a short way under ground.

All the nests consist of a tube excavated in the earth to a greater or less depth, unbranched in all but $\mathrm{D}$, and in every case lined with silk, this lining being continuous with the lining of the door or doors of which it forms the hinge.

I have found it convenient to distinguish these four types of nests by the following names:- $A$, the single door cork nest, or shortly the cork nest; $\mathrm{B}$, the single door wafer nest; $\mathrm{C}$, the double door unbranched nest; and $\mathrm{D}$, the double door branched nest.

The type B has only been found in the West India Islands, and is chiefly distinguished from $\mathrm{A}$ by having a thin and wafer-like door; wholly constructed of silk, without admixture of earth, lying on rather than fitting into the aperture of the tube; while in A the door is much thicker, made of layers of earth and silk, and so contrived that it tightly closes the mouth of the tube, which is bevelled to receive it, much as a cork closes the neck of a bottle. ${ }^{*}$

The West Indian nests are of a much tougher and coarser texture than those which I have seen in Europe, and vary somewhat in the shape of their tube, which is curved or straight, and sometimes has near its lower extremity a short spur-shaped enlargement, giving to the whole a ludicrous resemblance to a stocking, of which this spur is the heel.

Mr. Gosse, $†$ in his Naturalist's Sojoum in Jamaica,

* Nests belonging to the type A, are represented in Plates VII., p. 88, and VIII., p. 94.

† Gosse (P. H.), Naturalist's Sojourn in Jamaica (1851), p. 115-118. See also for another description of the same nest Latreille's Vues Générales sur les Araneides, in the Nouv. Ann. du Muséum (Paris, 1832), tom. i. p. 73-4. 
has given an admirable description of one of these single door wafer nests, the work of Cteniza nidulans, which I cannot do better than quote:-

The nest is "cylindrical, or nearly so, from four to ten inches deep, and about one inch in diameter; the hottom is rounded; and the top, which is at the surface of the soil, is closed very accurately with a circular lid. They are not all equally finished, some being much more compact, and having the lid more closely fitted than others. Some have irregular bulgings, and ragged laminated offsets on the outer surface; but all are smooth and silky on the inside.... The mouth of the tube, and the parts near it, are very strong; the walls here often haring a thickness of from oneeighth to one-fourth of an inch; but the lower parts are much thinner. The lid is continuous with the tube for about a third of its circumference, and this part may be called the hinge, though it presents no structure peculiar to itself ; it is simply bent at a right angle, as is manifest, if a nest be cut longitudinally through with scissors, the incision passing through the midst of the lid. The mode of construction, I judge, from examination of many nests, to be this. The spider digs a cylindrical hole in the moist earth, with her jointed fangs or mandibles, carrying out the fragments as they are dislodged. When the excaration has proceeded a little way, she begins to spin the lining which forms the dwelling. I conclude thus, because nests are occasionally found a few inches in length, with the lid and upper part perfect, but without any bottom, these being evidently in the course of formation. I suppose that she weaves her silk at first in unconnected patchos, against the earthy sides, 
perhaps where the mould is liable to fall in ; and thus I account for the loose rough lamine of silk that are always found projecting from the outer surface. These are overlaid with other patches more and more extensive, until the whole interior walls are covered; after which the silk is spun evenly and continuously all round the interior, in successive layers of very dense texture, though thin. Under the microscope, with a power of 220 diameters, these layers are resolved into threads laid across each other and intertwined in a very irregular manner; some are simple, varying from $\frac{1}{7000}$ to $\frac{1}{200}$ of an inch in diameter, and others are compound, several threads, in one part separate, being united into one of greater thickness which cannot then be resolved... The mouth of the tube is commonly dilated a little, so as to form a slightly recurved brim or lip; and the lid is sometimes a little convex internally, so as to fall more accurately into the mouth and close it.

The thekening of the hinge by additional layers is, I think, accidental only, as, out of the many specimens that I have examined, only one or two had such a structure. In the neatest examples, the lid is of equal thickness throughout its extent, agreeing also with the walls for the first few inches of their depth."

Mr. Gosse says that he possesses one specimen of peculiar compactness, which differs from all the others that he has examined in having "a row of minute holes, such as might be made by a very fine needle, pierced around the free edge of the lid, and a double row of similar ones just within the margin of the tube. There are about fifteen or sixteen punctures in each series, and they penetrate through the whole 
substance, the light being clearly seen through each hole. I do not think, as I have somewhere seen suggested, that they are intended to afford a hold for the spider's claws when she would keep her door shut against the efforts of an enemy, for what would be the use of having them in the tube close to the lid, so close that not the eighth of an inch intervenes between the surface of the lid and that of the tube, when the former is tightly closed? I would suggest whether they may not be air-holes, for so tight is the fitting of the lid, and so compact the texture of the material, that I should suppose the interior would be impermeable to air but for this contrivance." "The spider that inhabits this nest is black, with the thorax of an exceedingly lustrous polish, its abdomen is full and round, its legs very short."

Another form of this single door wafer nest is described by Mr. Sells, $\uparrow$ in which there is a hinge-like thickening of the silk lining of the tube about an inch beluw the actual hinge of the door, which it is suggested may serve to give additional elasticity. This was not found, however, in all the nests examined, and Mr. Sells conjectures that in newly constructed nests the lid may close sufficiently firmly without this contrivance, and that it is only added in older nests.

Patrick Browne's figure, to which reference has been made above, represents a nest with two doors, one applied against the other, at the mouth of the tube,

* I cannot myself think this explanation probable, and should still be inclined to consider these punctures to be the claw marks of the spider, as is the case in some European nests.

$+\mathrm{Mr}$. W. Sells. Notes respecting the Nest of Ctcniza nidulans, in Trans. Ent. Soc. ii. 207-210.

$$
\text { G } 2
$$


and it has often been asked what this could possibly mean.

Some have thought that the drawing was fanciful, others that it was made from an abnormal or injured nest. However, I believe that the drawing, though rude, is, in fact, not very incorrect, and shows a case of repair or enlargement of the nest, a subject to be treated of more fully further on. There is a specimen exhibited in the British Museum which in this respect very nearly corresponds with Browne's figure; it is labelled "Nest of Trap-door Spider with two doors, from the spirler having enlarged its abode.-Jamaica." Here one sees that the spider has prolonged its tube about half an inch beyond the original mouth of the nest, where it has constructed a new mouth and door, the old door standing straight up at the back of and behind the new one.

I imagine that the explanation of this curions piece of cobbling may be somewhat as follows:-When the nest was in its original state and had but one door, this door became by some accident covered over with earth to about the depth of half an inch, and the inmate was thus imprisoned. Then the spider, being, like most other members of its order, very unwilling to abandon its home, determined to clear away the entrance to its nest, and to lengthen the tube so that it should reach up to the new level of the surface of the earth. . . . If I am right, this should rather be called a lengthening than an enlargement of the tube.

The nests of the cork type (A,p. 7!) may usually be distinguished at a glance from those of the wafer type by the greater thickness of the door, and by its mamner of shutting, but a nest from Morocco has been figured 
and described by Prof. Westwood, * which seems intermediate between the two. The door in this case may perhaps be considered as of the cork type, though it is very thin, for it does fit into the mouth of the tube, which is bevelled to receive it.

These nests were forwarded with their living occupants (Cteniza [Actinopus] adificatorius) from Tangiers to Prof. Westwood, who describes the nests as being "about four inches deep, slightly curved within, about three quarters of an inch in diameter, the valve at the mouth not being circular, but rather of an oval form, one side where the hinge is placed being straighter than the other. The valve is formed of a number of layers of coarse silk, in the upper layers of which are imbedded particles of the earth, so as to give the cover the exact appearance of the surrounding soil, the several successive layers causing it, when more closely inspected, to resemble a small flattened oystershell.

The resemblance between this nest and that of the West Indian species is the more interesting as Prof. Westwood says that both belong to the same genus, (Cteniza or Actinopus of different authors,) and are so closely allied as to present scarcely any important distinction but that of size.

We shall find, however, on comparing the nests of these trap-door spiders and their occupants, that we cannot as yet make any rule as to the kind of nest which we may expect from a given spider.

* Obserrations on the Species of Trap-door Spiders, in Trans. of Entomological Soc., London, 1841-3, vol. iii. p. 175 .

I wish to take the present opportunity of thanking Prof. Westwood for having afforded me special facilities for examining this and other specimens forming part of the very valuable collections under his care at Oxford. 
It will be seen that species belonging to the same genus, and closely resembling one another, sometimes build dissimilar nests; while others, belonging to different genera, and unlike in many important respects, construct almost identical nests.

This is the more strange, because, if we examine the structure of the claws and palpi, they often seem to be specially adapted to serve as carding instruments and to play a very important part in the weaving of the silk linings of the nest; and yet nests of the same type are occasionally produced by spiders in which these appendages are quite unlike, and dissimilar nests where the claws and palpi are to all appearance identical.

Thus, for example, if the reader will examine the drawings of part of the foremost right foot of Cteniza fodiens, figs. A, 9 and 10, Plate VII., p. 88, with that of Nemesia camentaria, figs. A, 9 and 10, Plate VIII., p. 94, both of which make nests of the cork type, he will see that in the former the last joint of the tarsus is armed along the inner side, with many moveable spines, and that each of the two curved terminal claws has only one very strong tooth near the base; while the same joint of the latter (N.camentaria) has no spines, and the claws have three minute comb-like teeth near the base.

On the other hand, in the reverse case, where the structure of the same joint is very similar, the nests may be wholly unlike, as in Nemesia Eleanora, Plate XII., p. 106, and N. camentaria, Plate VIII., where the nest of the former is of the double-door unbranched type, and that of the latter of the single-door cork type.

It is probable however that a fuller and closer comparison of, and a more exact acquaintance with the 
several parts and their functions might show us that all spiders which spin similar webs are furnished with equivalent instruments, so that what one leg lacks another may possess in some shape or another; brushes of stiff hairs in one place, compensating for a toothed claw, or for a row of moveable spines in another.*

It would be interesting, from this point of view, to draw all the parts which may be supposed to aid in the act of weaving, and so to contrast the corresponding limbs of different spiders, the nests of which are known, that one might see at a glance in what they differed and agreed. I have done this for the falces and the last joint of the foremost right foot of the four spiders figured in Plates VII., VIII., IX., and XII., but to make the case complete all the limbs should be represented in the same way.

* The claws are probably of first-rate importance in this respect and should be most carefully stndiel. M. Lucas has stated that the claws of Mygale Blondii, and $\boldsymbol{H}$. nigru from Algiers, and of $M$.nigra and $M$. aricularia from Brazil, are retractile like those of a cat! Unfortunately the dwellings of these sprders have not been described. See Lncas (H.) in Rev. et Mag. de Zoologie, sér. 2, tom. ix. 1857, p. 587, and Ann. de la Soc. Eutom. de France, ser. 3, tom. v. p. exx., and vi. p. clxxi. Another curious point in which spiders differ is the presence or alssence of viscidity in the hairs which clothe their feet and palpi. Mr. Blackwall states (Spiders of Great Britain and Ireland, vol. i. p. 13), that by far the greater number of the suborier Territelaria, or Mygalicle as he terms them, "have the inferior surface of their biungulate tarsi, and of the digital joint of their pediform palpi, in the females, denscly clothed with compound, hair-like papillæ, constituting an apparatus which, by the emission of a viscous secretion, euables them to traverse the perpendicular surfaces of dry, highly polished bodies; others have three pairs of spinners and are destitute of hair-like papillæ on the legs and palpi."

The four species of trap-door spirler on the Riviera, here described, appear to form exceptions to this rule, however, for they all remained helpless prisoners when placed in a glass tumbler, though struggling vigoronsly for freertom.

When, however relying on this experience, I placed a number of smaller spiders of different kinds in glasses for examination some walkerl straight out without any difficulty, while others wcre unable to climb up the sides. 
Of the two spiders which are shown with their cork nests in Plates VII. and VIJI., the purplish grey Cteniza fodiens, (Plate VII.) appears to be much rarer than the brown striped Nemesia cementaria (VIII.), at any rate at Mentone. I have hitherto only succeeded in obtaining four specimens of the former, though I have searched repeatedly for them at Camnes and Mentone, while the latter species is tolerably common. The nests are, however, often extremely hard to find, and in some cases it is only by chance that I have been able to light upon them. All these trap-door spiders seem usually to prefer rather moist and shady places, and sloping banks or loose terrace walls where the interstices between the stones are filled up with earth, and concealment is afforded by the creeping lycopodium (Selaginella denticulata), Ceterach, spleenwort or maiden-hair ferns, with short moss and splashes of white lichen to distract the eye.

It was from such a terrace wall at Mentone, on March 26, 1872, that the nest A in Plate VII. was taken, the tube running obliquely back into the earth between the stones, and the door being concealed by a net-work of lycopodium, one spray of which had been allowed to grow on its upper surface.

'The tubes of these as of the other kinds of nest are sometimes straight, but more frequently they are bent, and almost always take a downward course.

The following is Mr. Pickard-Cambridge's description " of Cteniza fodiens, the spider which constructs this nest.

* The following description and remarks, printed in a different type, have been kindly prepared for this work by the Riev. O. Piekard-Cambriclge, to whom I sent a series of specimens of the spiders preserved in spirit of wine and their nests. My very sincere thanks are due to Mr. Piekard-Cambridge 


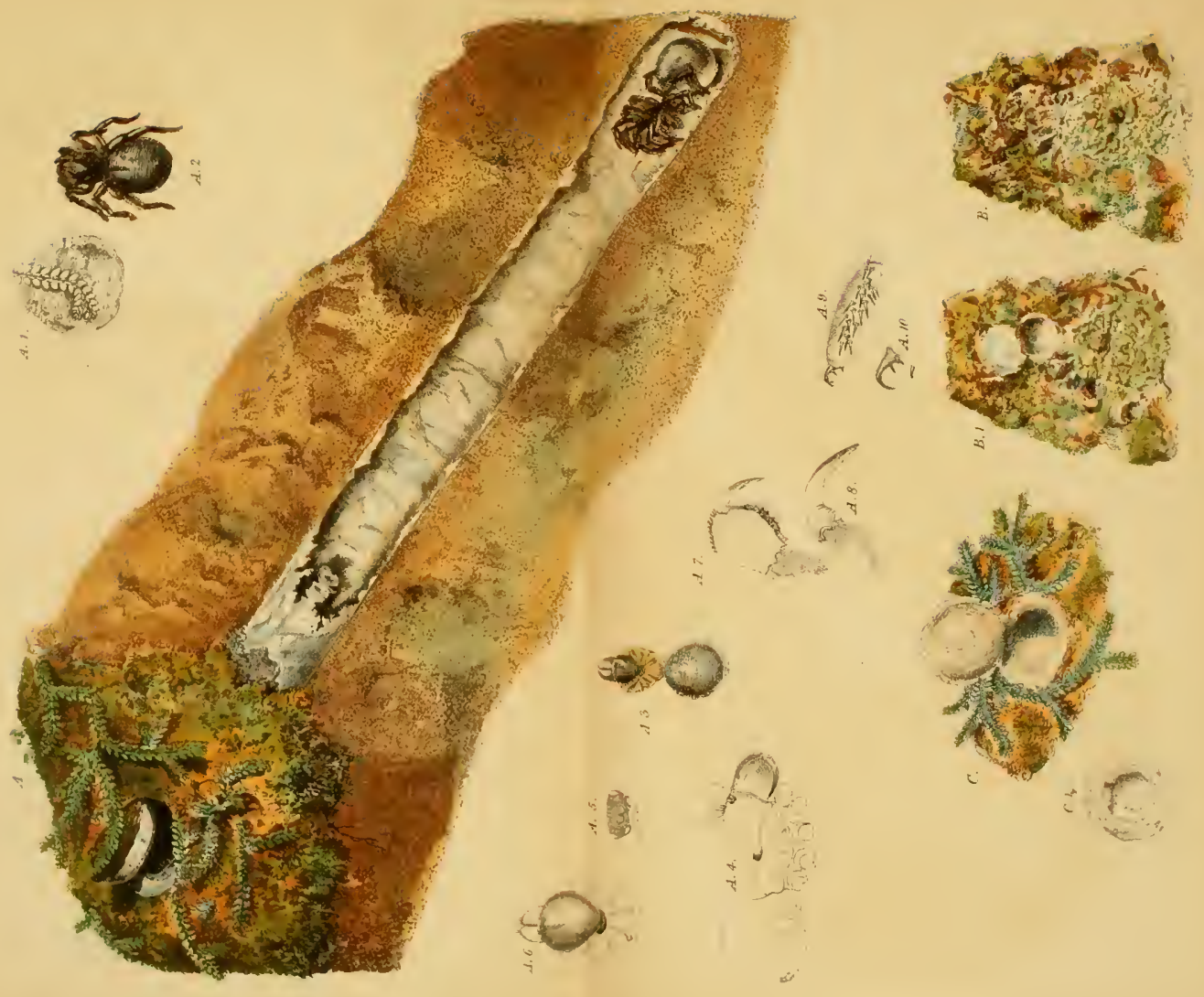





\title{
FAM. THERAPHOSIDES.
}

\author{
Gen. CTexiza, Latr.
}

Cteniza fodiens. Plate ViI.

Syn. Mygale fodiens, Walck. Ins. Apt., i. p. 237.

M. Sauvagei, Ausserer, Beiträge zur Ḱenntniss der Arachniden Familie der Territelaria (Thor.), p. 36.

Femule adult length 10 lines.

Cephalothorax oblong oval, snmewhat truncate at each end, and of a dull whitish-yellow brown colour, the normal grooves and furrows are strongly marked, the caput is large and elevated, rounded on the sides and slightly higher near the occiput than at the ocular area, the junction of the thoracic segments is indicated by a strong deep curved indentation, the curve directed backwards; there are a few strong black bristles of different lengths within the ocular space, and several others run backwards in the central line to the occiput. The height of the Clypeus is equal to rather more than the diameter of one of the foremost eyes. The Eyes are eight, and form a rectangular figure whose transverse diameter is the longest, and whose fore side is a little shorter than the hinder one; the longitudinal diameter is about equal to the space between the two foremost eyes; these are the largest of the eight, and are separated by an interval of very nearly two eyes' diameters; the two central eyes are the smallest, and are distant from each other just about one eye's diameter, the eyes of the hinder row are in two pairs forming the hinder corners of the rectangle, those of each pair are nearly contiguous to each other, and the inner one of each is the smallest; these last in the figure appear to be the smallest of the eight, but this arises from the point of view whence the figure was drawn; the two central eyes occupy as nearly as possible the centre of the figure formed by the two foremost eyes, and the two inner ones of the hinder row, and are seated on a large black spot. The

for this assistance, which will give to my publication a value in the eyes of Arachnologists which it conld not otherwise have possessed. To all those who wish to study the true structural relations of the four spiders, the habits of which are recorded in the following pages, these details will prove of the highest importance; while those who are only interested in the economy of these creatures can readily pass them over. For observers in the field there is a very realy way of knowing these four spiclers apart, as it will be seen that when they are somewhat alike the nests are different (Nemesia meridionalis and $N$. Eleunoru), and when the nests are alike (Cteniza fodiens and Vemcsia camentaria) the spiders are markedly dissimilar. 
Legs are short, strong, and similar to the Cephalothorax in colour, their relative length appeared to be $4,3,1,2$, they are furnished with hairs, bristles, and short strong spines. These latter are on those of the two first pairs, situated chiefly in two longitudinal parallel rows beneath the tibiæ, metatarsi, and tarsi; on those of the third pair they are situated on the sides and upper sides of those joints, while the fourth pair has them only beneath the metatarsi and tarsi; all the tarsi terminate with three claws, the two superior ones are much the longest and strongest, and have a single short strong tooth inside near the base. Near the union of the femora and genuæ of the legs of the fourth pair are numerous short strong spines, hairs, and bristles. The Palpi are similar in colour to the legs; they are strong and about equal in length to the legs of the second pair, and have a double longitudinal row of strong spines widely separated and divergent from each other beneath them; the digital joint (like the tarsi of the legs) is furnished with other spines between these two rows; each palpas terminates with a single untoothed curved claw. The Falces are strong, prominent, rounded in the profile line, and have some hairs, bristles, and spines near their fore extremities; the longest and strongest of the spines are three in number, and form a kind of transverse row or comb at the extreme inner point on the upper side of each falx; besides these there is a row of short toothlike spines on either margin of the furrow on the under side of each falx in which the fang lies concealed when at rest. The Maxilla are short and strong; the palpi issue from their extremity on the outer side, and the inner extremity is somewhat prominent and pointed.

The Labium is small, short, somewhat rectangular in form, and broader than high; the apex is a little rounded, and furnished with a single transverse row of small tooth-like spines.

The Sternum is somewhat subtriangular in form, much broader behind, where it is rounded on the outer angles.

The Abdomen is short oval, very convex above, where it is of a yellowish vinous brown colour, with a slightly darker longitudinal tapering, indistinct central stripe on the fore part; it is sparingly clothed with hairs, and the under side is of a pale dull yellowish colour ; the spinners are four in number, and those of the superior pair are the strongest, three jointed and upturned.

Adults and immature examples (all females) were found in tubular holes lined with silk and closed at the orifice with a strong solid hinged lid, shutting into the opening like a cork. 
The portions of nests at $\mathrm{B}$ and $\mathrm{C}$ in Plate VIT. also belong to Cteniza fodiens, the latter being very similar to $\mathrm{A}$ in its surroundings, but having a rather thinner door, slightly hollowed out above (C 1). The smaller nest shown shut at $\mathrm{B}$ and open at $\mathrm{B} 1,{ }^{*}$ is admirably concealed by mosses and lichens, some of which actually grow upon the door, and here two minute trap-doors, belonging to infantine examples of a distinct species of spider (Nemesia meridionalis), are seen on the left hand below.

It is not rare to find small colonies of nests of the same or distinct species grouped closely together in this way, though I greatly doubt whether one can safely assume their sociability from this fact.

I have very seldom seen nests on the flat ground, where the door would lie horizontally when closed, a sloping or nearly vertical bank being usually chosen, where the door will fall to by its own weight.

In the Ionian Islands another species or variety of Cteniza, described under the name of Cteniza (or Mygale) ionica, and represented as being of an uniform yellow-brown colour, is said to make its nests in the earth of the terraces round the roots of the olive trees.

Mr. Saunders $\dagger$ gives admirable figures and descriptions which show us at once that these nests, which he discovered in rather elevated situations in the island of Zante, are of the cork type; but, in this case, the entire door does not shut flush with the surface, as in

* It must be clearly understood that when the doors are represented as standing open or ajar this is unuatural, as they always close by their own combined weight and elasticity.

† Sydney Smith Saunders. Description of a Species of Mygale from Ionia, in Trans. Ent. Soc. London, 1839, vol. iii. p. 160, Plate IX. 
ordinary cork nests, but has a short spur-like projection above and behind the hinge, serving, as is conjectured, like a lever, by pressing on which from the outside the lid may easily be raised.* When I come to speak of the manner of constructing and repairing nests I shall have occasion to refer to these nests again.

I have not as yet found any nests on the Riviera which can be said to correspond accurately with those of $\mathrm{Ct}$. ionica, the only builders of cork nests yet discovered in this district being Cteniza fodiens and Nemesia comentaria.

This latter species is described by Mr. PickardCambridge, $\uparrow$ in the following terms:-

\section{Gen. Nemesia (Savigny).}

Nemesia Cementaria. Plate IX.

Syn. Mygale ccementaria (Latr.), HI. N. des Crust. t. vii. p. 164 .

M. comentaria (Walck), Ins. Apt. i. p. 185.

Female adult, length 9 to 11 lines.

Cephalothorax rather elongate, oval, and somewhat truncated at each extremity; the caput is elevated and rounded on the sides and upper part, but less elevated than in Cteniza; the normal grooves and indentations are well marked, and the junction of the cephalic and thoracic segments is indicated by a strong deep impression or cleft, of a transverse, eurved, or somewhat bent angular form, -the curve or angle directed forwards. The colour of the cephalothorax is yellow-brown tinged with olive, the margins are paler, but have no distinctly defined marginal band. On the hinder part of the caput are three clear brown-yellow longitudinal stripes; the central one reaches from behind the two hind central eyes to the thoracic junction, the lateral ones converge a little to

* I must own to some hesitation about accepting this explanation, though I am not prepared to offer any other.

t See above, p. 88. 
the same point, but do not reach nearly, in fact not much more than half way, to the eyes. The clypens is of a clear brown-yellow colonr also, and on either side of it (extending from each fore lateral eye), is an irregular patch of the same. The ocular region and clypens are furnished with a few strongish black bristles, and the three yellow stripes above mentioned have a few more, those on the central stripe being the longest and strongest, and disposed in a single longitudinal row.

The Eyes, eight in number, are seated on a transverse oval eminence, and form a rectangular figure, whose transverse diameter is double the length of its longitudinal diameter: their relative position is similar to that of Cteniza, but in the present species they are smaller than in $C$. fodiens : those of the hind central pair are the smallest of the eight, and each is very nearly contiguous to the hind lateral on its side; the interval between those of each lateral pair is small; the space between the two central eyes of the eight is equal to an eye's diameter, and each of these is separated from the hind central and fore lateral nearest to it by a similar interval. The Legs are strong, moderately long, their relative length $4,1,3,2$ ?, but little difference is observable between 1, 3, and 2 ; they are furnished with hairs, bristles, and a few, not very strong, spines; each tarsus terminates with three curred claws, the two superior ones much the longest and strongest, and have a few small teeth near their base inside.

The Palpi are strong and similar in colour and armature to the legs; each is terminated with a curved black claw.

Falces strong, prominent, and rounded in the profile line; they are furnished with hairs, bristles, and strong tooth-like spines; the four strongest of these latter form a transverse row at the inner extremity of each; besides these there is a row of short toothlike spines on the inner margin of the furrow on the underside of each falx, in which the fang lies concealed when at rest. The Maxille are strong, with a small angular prominence at their inner extremities (when looked at from beneath), and each has three to four small dark-coloured teeth in a short, straight, obliquely transverse row at the base on the inner side. Labixm broad but short, its breadth is double its height, and the upper corners are rounded off. The Sternum is of a somewhat pentagonal form.

Abdomen rather elongate oval, tolerably, but not excessively, convex above; it is of a dull yellowish whitey-brown colour marked and mottled above with dark chestnut brown; the markings are rather irregular, but a general disposition in the form of 
a longitudinal central, and oblique lateral, stripes or bars may be traced on the hinder half; the superior spimners are short and three-jointed, those of the inferior pair are exceedingly minute.

Adult females were found in nests similar to those of Cteniza fodiens.

The cork nests are the simplest form of nest, with the exception of those described above from Jamaica, and have constituted, up to the present time, the only type known in Europe. Their chief claims to our admiration lie in the perfection of workmanship which the doors usually exhibit, and the marvellous concealment which they afford when closed. These doors as a rule fit so tightly [thanks to the accurate adjustment of their sloping sides to the bevelled lip of the tube which receives them, ] that they afford a certain amount of mechanical resistance, even when the spider is away. But, after examining a very large series of these cork nests, I find that there is some variation in the degree of perfection attained in their work by different individuals of the same kind. The mechanical resistance is greater or less in proportion to the thickness and weight of the door, and to the slope of its sides, and of the bevelled edges of the tube; and in each of these details a marked difference may be observed.

One might suppose from what has so often been repeated as to the habits of $N$. camentaria, that, whenever any one attempts to open the door, the spider, which is always at home in the day time, would dart up from the bottom of the tube and endeavour to keep it closed by holding on from within.

I cannot say what may take place during the summer months; but from October to May I have but rarely 


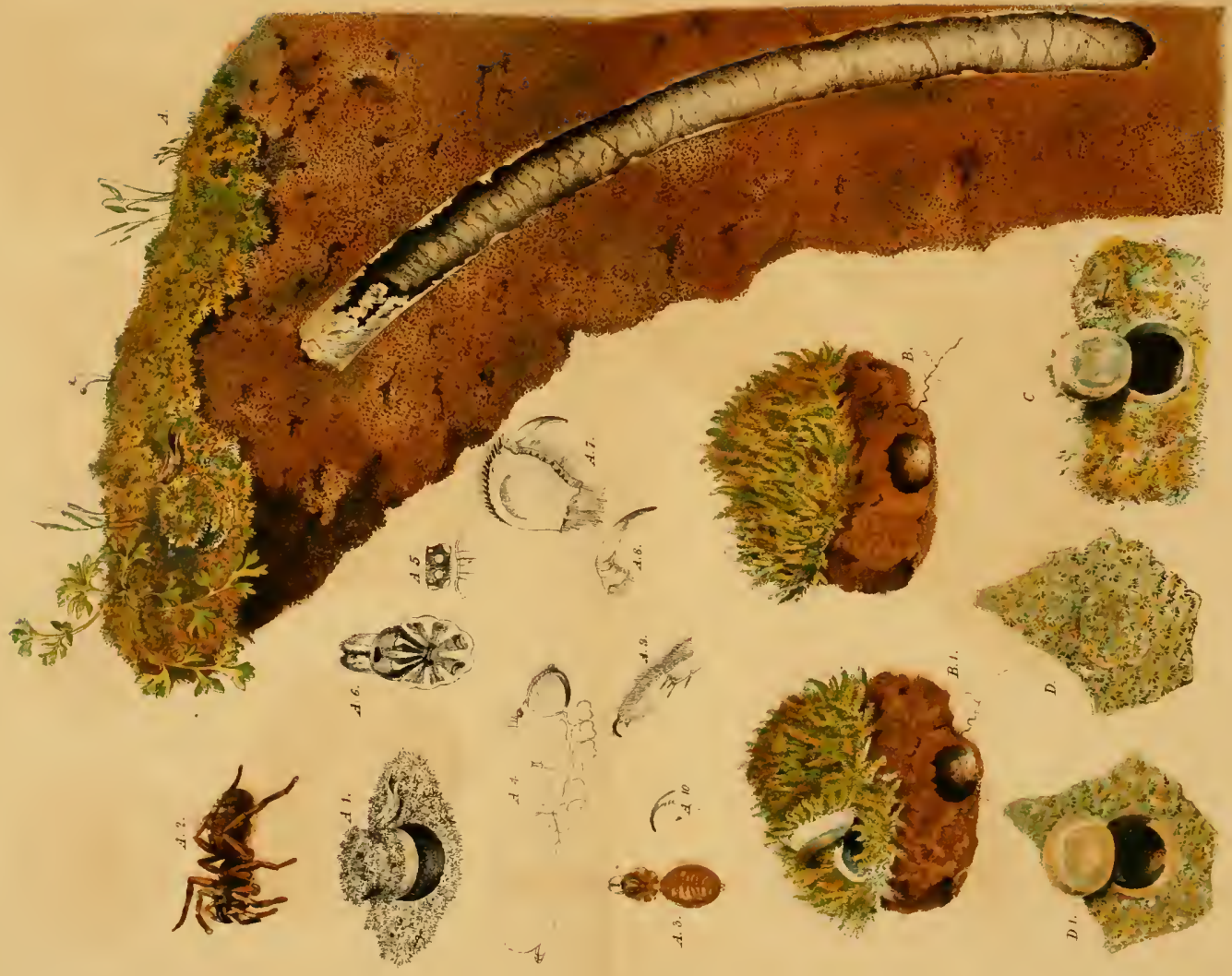



found one of these spiders ready to oppose me, though Nemesia meridionalis and $N$. Eleanora frequently did so. Many times, wishing to provoke them, I have tapped at the door in order to apprise the occupant of my arrival, or lifted it and let it fall again, and always in vain, though the spider was there, crouching at the bottom of her tube.

Indeed I can only recall six or eight instances in which this spider did hold down her door, and on three of these she was captured.

I will now relate what I saw on one of these occasions, * for there has been much speculation as to the manner in which the spider clings to the door and offers the determined resistance which is experienced.

No sooner bad I gently touched the door with the point of a penknife than it was drawn slowly downwards, with a movement which reminded me of the tightening of a limpet on a sea-rock, so that the crown which at first projected a little way above, finally lay a little below the surface of the soil. I then contrived to raise the door very gradually, despite the strenuous efforts of the occupant, till at length I was just able to see into the nest, and to distinguish the spider holding on to the door with all her might, lying back downwards, with her fangs and all her claws driven into the silk lining of the under surface of the door. The body of the spider was placed across, and filled up, the tube, the head being away from the hinge, and

\footnotetext{
* Mrs. Boyle was the first to witness this curious sight, and my description of the resistance of the spider is almost an exact repetition of hers to me. It is curious also that, following her indicatious, I found the very nest and spider on which she had made her observations, and every detail recurred again though several days had elapsed between her visit and mine.
} 
she obtained an additional purchase in this way by blocking up the entrance.

I did not force the spider to release her hold, but, by a rapid stroke with a long-bladed knife, cut out the upper part of the tube with the surrounding mass of soil, and thus secured the trap-door and its owner. This specimen is represented at fig. C, Plate VIII., where the pin-point holes made by the claws may be seen in pairs round the whole circumference of the flatter portion of the lower surface of the door except on the side next to the linge.

Whenever a spider resists in this way she must make these holes, but I have very rarely seen them in other nests; this may perhaps be accounted for by their having been effaced by the action of moisture which would stretch the silk. However this may be, this specimen showed the claw marks quite distinctly on my return to England after the lapse of several weeks.

Much has been written about these marks, which are frequently spoken of as holes purposely made in the silk in order to give the spider a better purchase. It has also been stated that two holes may be seen in the silk of the tube near the mouth on the side away from the hinge, but these I have never been able to find. The door of nest $\mathrm{A}$ in Plate VIII. is rather abnormal, as it is made up of two doors, the smaller one being spun into the top of the one now in use. This is, I believe, an abnormal and rather clumsy example of the ordinary way of enlarging the nest, but of this we shall see more when we come to speak of the construction and repairing of these nests generally. 
Fig. B in this plate represents a moss-covered sod pierced by the tube of a nest, the door of which is entirely concealed from view, and only discovered when opened as at B 1 .

This nest was found accidentally by Mr. Robert Iightbody, who kindly brought it to me, its presence having been betrayed by the tube, which he happened to cut through in digging up a plant. The moss on the door grew as vigorously, and had in every way the same appearance, as that which was rooted in the surrounding earth; and so perfect was the deception that I found it impossible to detect the position of the closed trap even when holding it in my hand. There can be no doubt that many nests escape observation in this way, and the artifice is the more surprising because there is strong reason to believe that this beautiful door-garden is deliberately planted with moss by the spider, and not the effect of a mere chance growth. I shall adduce evidence in support of this statement by-and-by.

I alluded to the nest C (Plate VIII.) when speaking of the claw marks which it exhibits, and that figured at D and D 1 in this plate is merely an instance of a good example of this type. I lave taken nests of $N$. cementaria both at Cannes and Nentone, and have little doubt that this species will be discovered at many points along the Riviera. I detected two abandoned nests of the cork type, which I fully expect had belonged to $N$. camentaria, in an enclosed space called the Campagne de Garonne in Marseilles itself. These nests lay in the little mound of undisturbed earth between the divided trunks of the small olive-trees, and I do not doubt that if I had had time 
to search I should have discovered more nests, and perhaps others which were still tenanted.

We now turn from the single-door nests to those with double doors, and from the well known to the new types of structure.

In these we have a thin and wafer-like door at the mouth of the nest, and from two to four inches lower down, a second and solid underground door. These lower doors are characteristic of the nests to which they belong, that of the branched nest (Nemesia meridionalis, Plate IX.) being long and more or Jess tongue-shaped, while that of the unbranched doubledoor nest (N. Eleanora, Plate XII. p. 106) is somewhat horse-shoe shaped.

The surface doors of these two kinds of nest do not appear to differ, and, though rather thinner, may be compared to those of the single-door wafer kind from Jamaica.

The commonest form at Mentone is the branched nest, which may be found in abundance in many of the loosely-built walls of the lemon and olive terraces or on sloping banks, but they are rarely to be met with on flat ground.

In the nests of Nemesia meridionalis the tube, instead of being simple, as it is in all other known nests, is invariably branched, a second tube joining the first at the point where the lower door is hung and forming with it an angle of about $45^{\circ}$. The main tube descends and is frequently curved, or sometimes doubly bent like the spout of a tea-kettle ( $A$, Plate X. p. 100), while the branch ascends, and in some few instances reaches the surface, though it is usually a cul de sac (Plate IX.) 


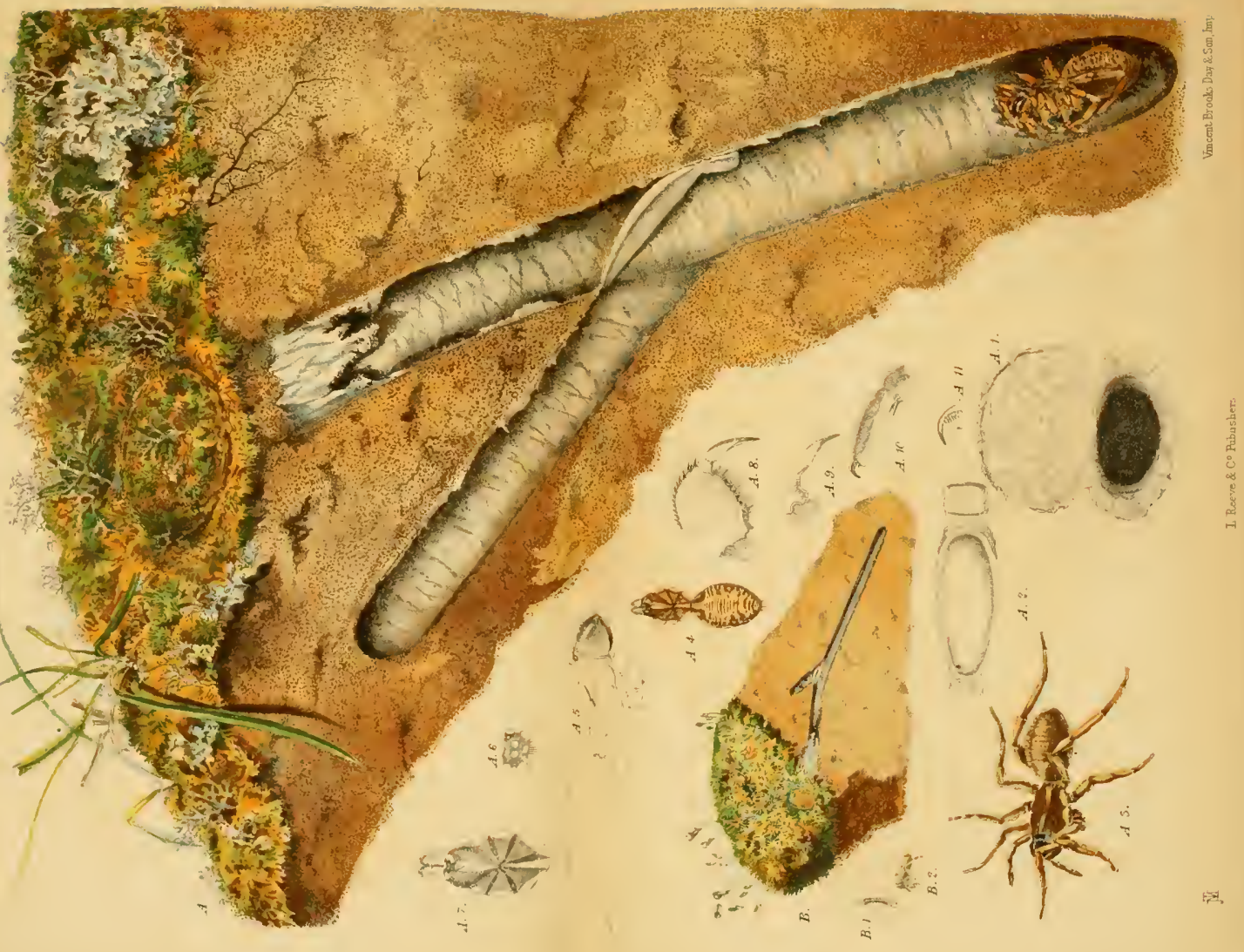



In the exceptional cases where the nests have two superficial openings, one of the two surface doors always appears neglected and going to decay, or is covered with earth which chokes the upper part of its tube. The explanation of this probably is that the spider found the original entrance blocked up or in some way unfitted for use, and then prolonged what was the blind branch until it reached the surface and replaced the former doorway. However this may be it is certain that in the great majority of nests it will be found that the branch ends in the earth, and is a cul de sac, and this I have invariably observed to be the case in the nests of very young spiders of this species (fig. B, Plate IX.)

The tube is frequently enlarged at the mouth, and forms a spreading lip which the surface door is usually large enough to cover (A 1, Plate IX.)

In these branched double-door nests the upper door does not fit into, but merely lies upon, the mouth of the tube, the elasticity of the hinge and its own weight being sufficient to keep it closed. The lower door is suspended by a hinge placed at the apex of the angle formed by the bifurcation of the tube, and is hung in such a manner that it can either be pushed upwards so as to lie diagonally across and block the main tube, or be drawn back so as to fit into and close the entrance to the branch.

This will, I think, best be understood by reference to the drawings of a small nest of this type given at B 1 and $B 2$ in Plate XI. p. 105, where the second door is shown in its two positions. This lower door is from 1 to $1 \frac{1}{2}$ lines thick, channeled above, but nearly flat on the back, and of an elliptic form, with a loose ap- 
pendage at its lower end, the whole being made of earth enclosed in a case of silk.* "When the lower door is drawn back so as to close and conceal the entrance to the branch, it lies in the same plane, and closely corresponds in curvature with the lining of the main tube and almost appears to form part of it (fig. A, Plate X. p. 100, and fig. B 1, Plate XI. p. 105).

When digging out these nests, after carefully removing the upper portion, I have frequently seen the lower door move across and block up the main tube in a mysterious manner, it being in reality pushed by the spider from below, and she may sometimes be captured at her post with her back set against the door. More frequently, when the spider finds that resistance is hopeless and sees the earth crumbling in, she drops to the bottom of her nest and lies there helpless, with her legs folded against her body like an embryonic creature; some, however, more savage than their neighbours, fly out and strike at the intruder with their fangs.

What then, it may be asked, is the use of the branch? I do not think that we can draw any safe

* Since writing the above I have learned, thanks to a better method which I have recently adopted for preserving the nests for examination, that sometimes the lower door, instead of being free within the tube and only attached to the lining by the hinge, is surrounded on either side by a delicate silk web, which extends from either edge of its lower surface to the silk walls of the tube below and forms a sort of double gusset. This admits of the movement of the lower door in the way described above, but perhaps serves, together with the solid appendage at the extremity of the free end of the door (that away from the hinge), to prevent the door from being driven too far in an upward direction and thus becoming so tightly jammed as to make the spider a prisoner in her own nest. I think it possible that the lower door is always attached to the tube in this way, but, as it parts readily from the silk on either side when the earth which supports the tube is removed, it very frequently appears to be free, as $I$ have represented it in Plates IX., $\mathrm{X}$, and $\mathrm{XI}$. 


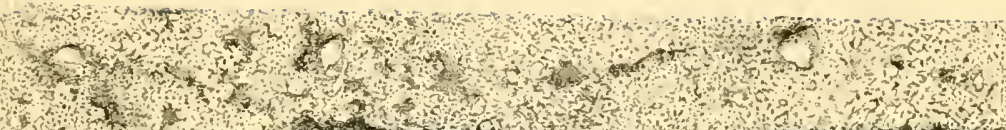

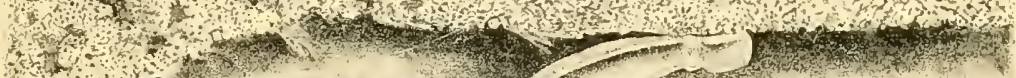

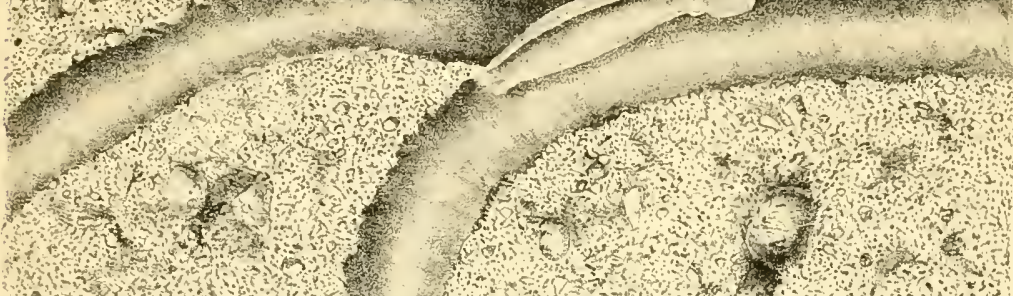

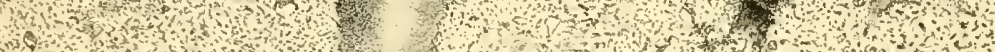

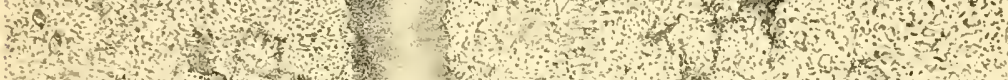

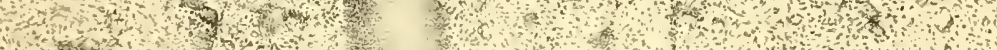

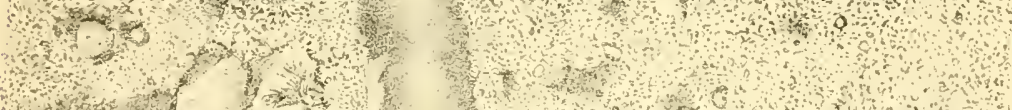

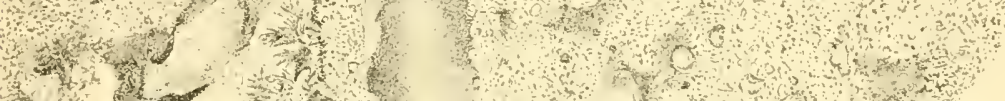

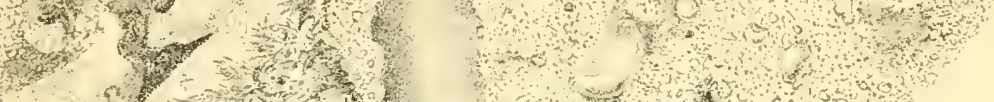

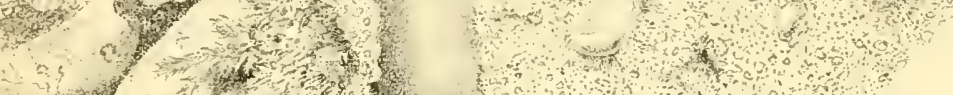

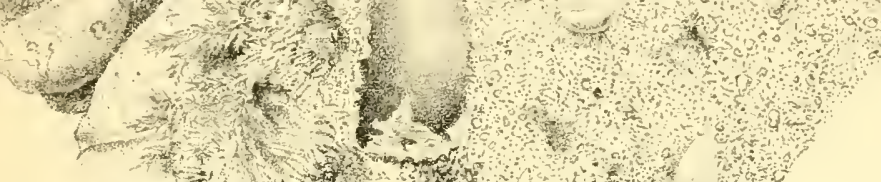

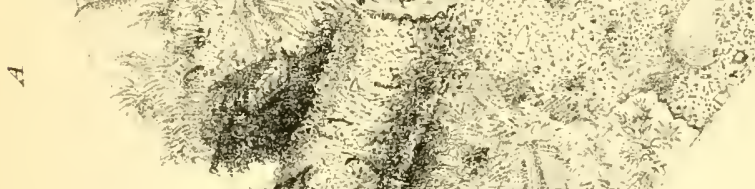

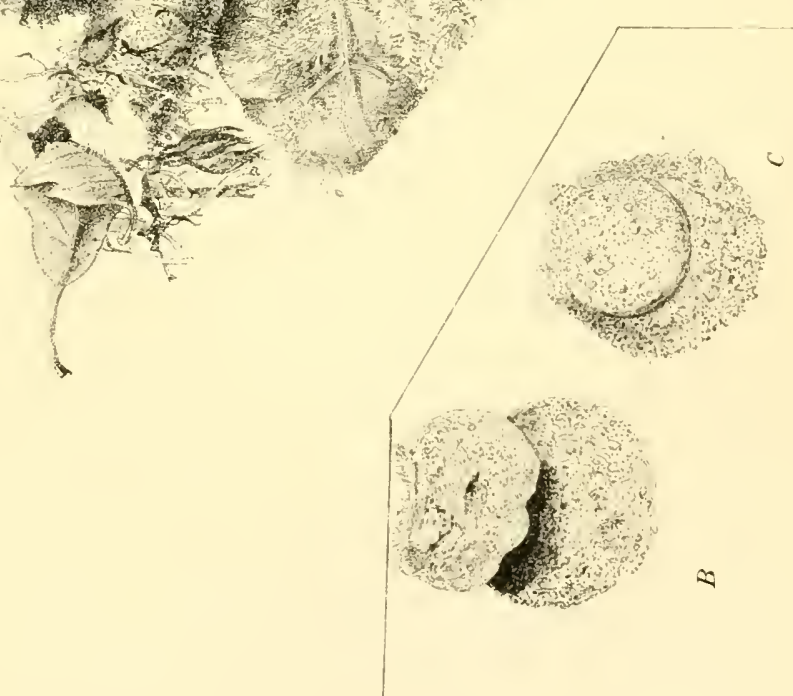



conclusion from what takes place when we dig out a spider, as to what would occur if she were besieged by one of her natural enemies, such as ichneumons, sandwasps, centipedes (Scolopendra), small lizards \&c.*

Let us suppose, however, that one of these creatures has found its way into the nest and is crawling down the tube. What will probably happen? Why, in the first place, the spider will slam the second door in the face of the intruder, and then, if worsted in the pushing match which follows, quickly draw this door back again and run up into the safety branch, when the enemy, after descending precipitately to the bottom of the main tube, will look in vain for the spider as it searches on its way up for the secret passage now closed by its trap-door. This is but a purely imaginary case, and it may be that the branch has some wholly difierent purpose.

It seems very improbable, however, that it should be mainly intended as a safety place for the eggs or offspring; at least if this were the case we should not expect to find it, as we do, in the nests of very young spiders (fig. B, Plate IX.), which could have no use for it.

The large spider and its nest figured at $\mathrm{A}$ and $\mathrm{A} 3$ in Plate IX. were taken at Mentone on March 17, 1572 , and the following is the technical description of the species, written by $\mathrm{Mr}$. Pickard-Cambridge:-

Nemesia Meridionalis. Plate IX.

Syn. Mygale meridionalis (Costi). Fauna del Regno di Napoli, p. 14, Pl. I., figs. 1-4, ad partem.

Female adult, length 11 to 13 lines.

This spider is very nearly allied to $\boldsymbol{\Lambda}^{T}$. camentariu both in general structure and colours, but it may be distinguished by the

* For some account of the principal enemies of spiders generally, see p. 134. 
more elongate form both of the cephalothorax and abdomen; the colours also of the present species are more distinctly distributed; a well-defined narrow marginal band, irregular on the inside, surrounds the thorax; and the caput has a large curved patch of the same on either side of the ocular area, with a broad tapering band tinged with orange, which runs from immediately behind the eyes to the thoracic junction, where it ends in a point. The transverse diameter of the ocular area is also less in proportion to its longitudinal diameter than in $N$. ccementaria, and the eyes are all smaller, but placed on a similar oval eminence, and several bristles are directed forwards from the middle of the lower margin of the clypeus, while one or two others are found in the ocular area, and three or four more (long, strong, and nearly erect) form a longitudinal row along the middle of the central tapering thoracic band. The Falces are deeply yellow-brown, with two to three elongate oval patches or short longitudinal parallel bands on their upper sides; in their armature the falces are similar to those of $N$. comentaria. The Labium appeared to be less broad in proportion to its height, and the Stermum smaller and of a more oval form than in that species. The Abdomen is similarly marked, though the chocolate-brown markings appeared to be less deep and dense, being more broken up, but still forming several fairly defined, bold, and broad angular bars or chevrons on the upper side. The inferior spinners, though small (like most of the corresponding pair in species of this family), are yet considerably stronger than in $N$. comentaria.

Adult females of this spider were found in tubular silk-lined holes in the earth, closed at the external orifice with a flat scalelike hinged lid, covered with lichens and mosses. Not quite half way down this tube is a tubular branch running off upwards at an angle of $45^{\circ}$ or less; the main tube also at this point is furnished with an elliptical-hinged valve, with which the spider appears to have the power to close the entrance to the brancls or to shut off the upper part of the main tube. This branch (found also in the tubes of very young examples) seems to be certainly a strong distinguishing character in the economy of the species, and separates it at once from $N$. comenteria. In the nest of $N$. meridionalis the tube also projects at times above the surface of the soil upwards anong the herbage which serves to conceal it. Costa appears to have had before him this latter species as well as what is liere taken as the typical N. meridionalis, as he speaks of the nests under his observation as being frequently branched, while his description would suit both species; his figure, however, more 
nearly agrees in the thoracic pattern with the spider above described. Ausserer, in his elaborate paper on the Mygalides, lately published (Beiträge \&c. vide supra), appears to have overlooked M. merilionalis (Costa) altogether; while Canestrini and Pavesi (Catal. degli Araneidi italirni in Atti Soc. Ital. Sc. Nat. xi. (1869), p. 25 , include it under the synonyms of $M$. fodiens Walck., from which it is undoubtedly distinct, as may be seen at once, even if it were only by the difference in the form and structure of the lid with which the external orifice of the tubular nest is closed.

In the case of the upper door of these branched nests, as there is but a very thin coating of earth on their upper surface, it is rare to find any of the larger mosses or lichens growing upon them; but, as if to compensate for this deficiency, a variety of foreign materials are employed which are scarcely ever found in cork doors, such as dead leaves, bits of stick, roots, straw of grasses, \&c., and I have even seen freshlycut green leaves, apparently gathered for the purpose, spun into a door which had recently been constructed.

But here again there is the widest possible difference between nest and nest in the degree of perfection in their concealment; and, although as a rule the surface of the upper door harmonizes well with the general appearance of its surroundings, there are some individual nests in which it readily catches the eye and even attracts attention.

Thus, I have seen nests in mossy banks where the doors, being made of nothing but earth and silk, showed distinctly as brown patches against the green; and those doors which are corered with earth only, even when they are surrounded by earth, are often easily detected, because when they dry up, as they quickly do, they become much paler in colour than the earth of the bank, which retains its moisture. 
Perhaps in no case is the concealment more complete than when dead leaves are employed to cover the door. In some cases a single withered olive leaf only is spun in and suffices to cover the trap; in others, several are woven together with bits of wood and roots, as in the accompanying woodcut, which represents different views of the upper door of the nest which is drawn in Plate X. p. 100.

In this nest another interesting feature presents itself, for here the tube projects a short way beyond the surface of the ground and is hardened and coated

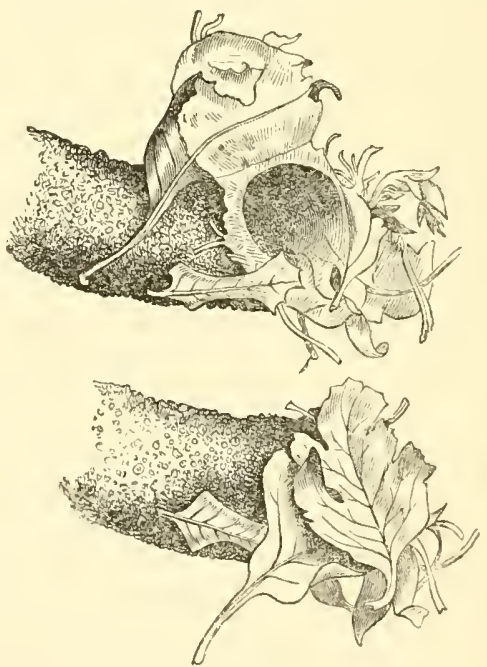

with earth and fine gravel in such a way that it requires no other support. This is not commonly the case, and may perhaps be the result of a contrivance to meet the necessities of a nest which has had the surface earth washed away from it. But I have frequently observed nests in which the upper part of the tube is carried up for two or three inches through 



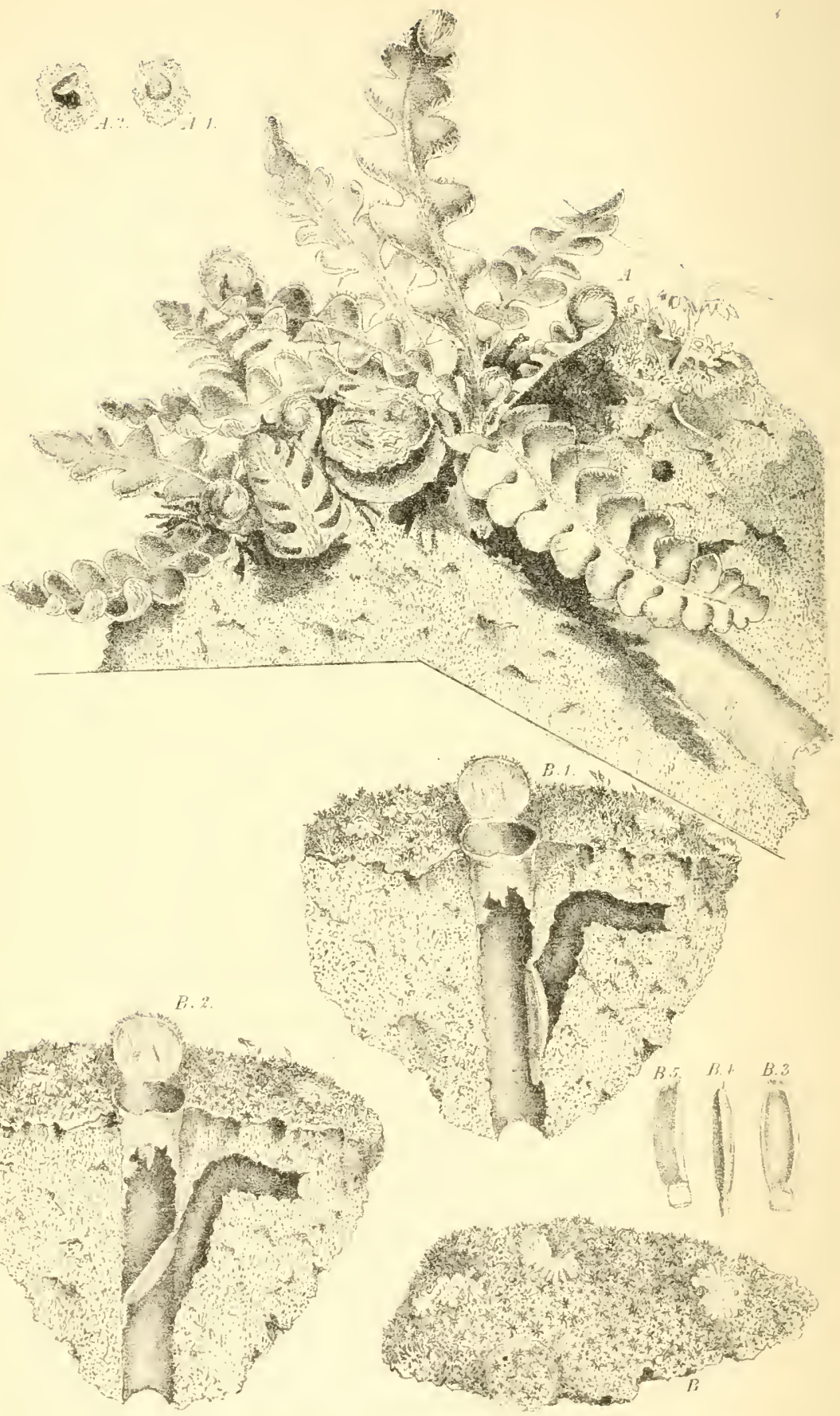

Vincent. Brooks Day \& Sou, inf 
grass, moss, ferns, pellitory, or the like, the stems of the sheltering plants being interwoven with and made to support the tube.* In every case the second door, which is designed for resistance and requires a firmwalled tube into which it may be wedged, is below ground, and for the same reason we scarcely ever find cork nests constructed with any part of the tube projecting beyond the surface of the soil.

At fig. A, Plate XI., one of these branched nests is seen concealed in a plant of ceterach fern, and here the tube is raised a short way above the soil; while in fig. B of the same plate the common form is represented, the upper door lying flat on the surface of the ground, from which, thanks to its covering of small niosses, it is scarcely to be distinguished.

The figs. B 1 and B 2 show this door open and the lower door in its two positions.

Now that attention has been drawn to the existence of this new type of nest, I fully expect that Nemesia meridionalis will be found at many points along the Riviera and in the whole Mediterranean region, but I have hitherto only discovered it at Mentone and Cannes. Mirs. Boyle saw one of these nests in the Pallavicini gardens near Genoa, and there seems every reason to believe that certain nests which have been detected near Naples and in Ischia, will, when better known, be found to be of the branched double-door type.

It seems probable that our spirler belongs to the species which was first described by M. Costa, $\uparrow$ under

* This aërial portion of the tube corresponds with that of Atypus piccus described above (p. 73), but differs in having its aperture elosed by a door.

+ Fauna del Hegno di Napoli, (vol. containing Animali Articolati, classe ii. Aracnidi : incomplete, Naples, 1861), p. 14, tab. i. figs, 1-4. See Appendix A. 
the name of Mygale meridionalis, though, if we are to rely implicitly on the figures and detailed account given by this naturalist, we must suppose that it constructs a different nest in Southern Italy from that which it makes on the Riviera, and one which, although it agrees in most other respects, is destitute of the characteristic subterranean door.

It is more likely, however, that M. Costa has overlooked the existence of the lower donr, though it is strange that he should have done so, as lie says that the nests "sometimes liave a double aperture, and the upper portions of the burrows meet and anastomose at about two inches distance," thus showing that he was aware that the tube is branched.

One more nest only now remains to be described, and this is again an example of a new type--namely, of that which I have distinguished as the unbranched double door (Plate XII.), the work of Nemesia Eleanora. This nest is never branched, and its second and subterranean door is situated from one to four inches below the surface door, and only serves to close the one tube which is narrowed above the insertion of this lower door. Here, as in the branched nest, the thin and wafer-like surface door appears to serve principally for concealment and the lower one for resistance. This latter, made out of earth encased in strong white silk, is from one to two lines thick, and has, at the end away from the hinge, a similar appendiage to that found in the lower door of the branched nest. This appendage serves, I imagine, as a kind of car by which the door, when firmly jammed into the tube on the approach of an enemy, may be pulled down again as soon as the alarm is over. As 


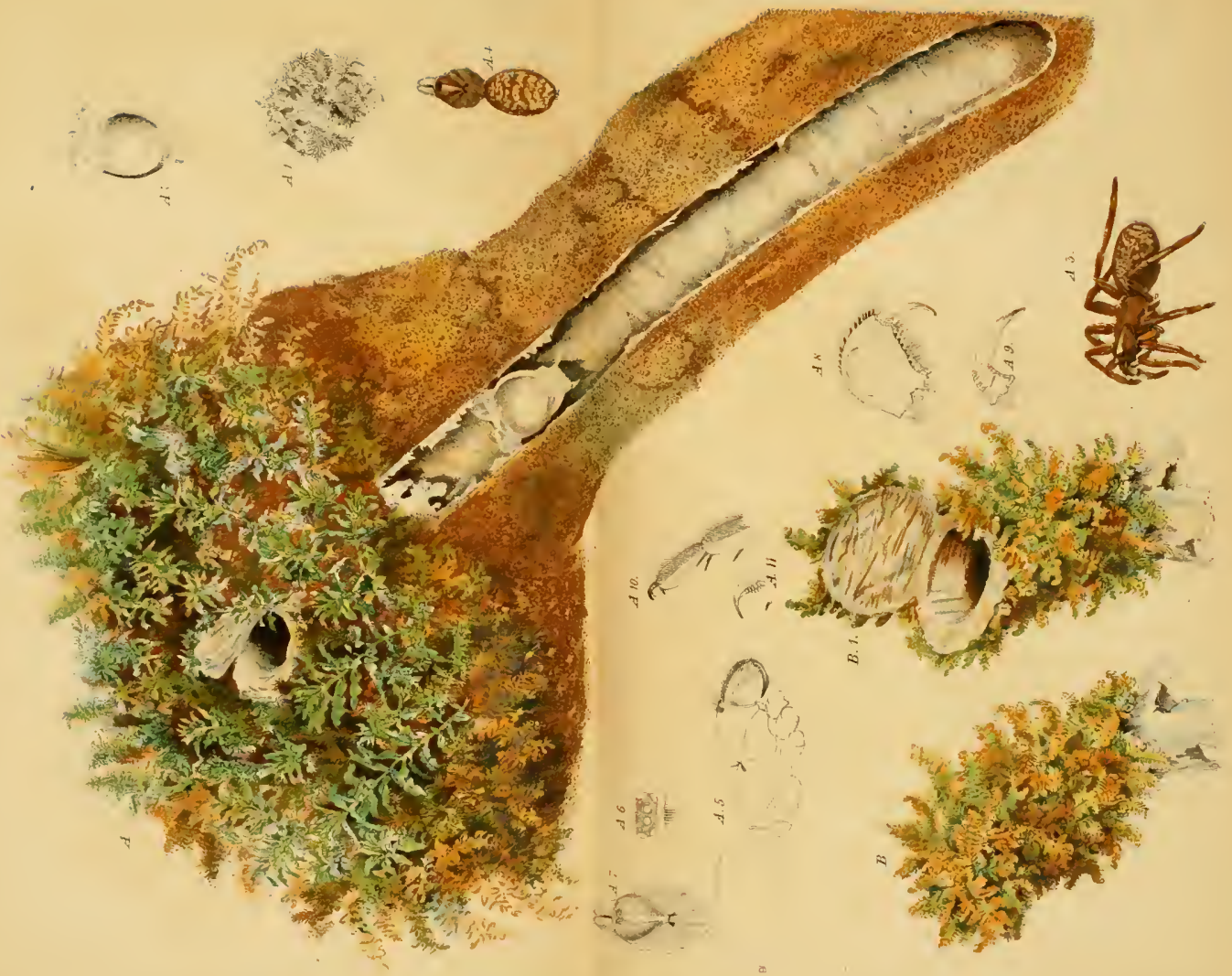



in the branched nest it has the upper surface concare and the lower slightly rounded, so that when drawn back and not in use it may not obstruct the passage. 'The sides of this lower door slope a little, so that the crown is smaller than the base: and this is important, because it causes the door to fit more tightly when driven upwards into the tube, acting on the principle of an inverted cork door.

In form this door is somewhat elliptic, but much broader and shorter than the second door of the branched nest, and it is frequently of a nearly horseshoe shaped outline. The second door of the branched nest is necessarily longer, having to perform the double function of closing the opening to the branch and the passage of the main tube.

In either case, however, these doors will be found to be more or less elliptic, and this is necessarily so, for, lying as they do when in use in a plane which cuts the subcylindrical tube obliquely, they have to fill a somewhat elliptical area.*

I have observed some variation as to the exact proportions of these doors, and it is quite possible that in many cases they are specially adapted to meet. peculiarities in the curvature of the tube.

\footnotetext{
* The lower door here, as in the branched nest (see above, p. 100), is sometimes united to the silk of the tube below by two nearly triangular gussets of silk, when, instead of being free except at the linge, as I haverepresented it (Plate XII.), it is surromuded on either side by silk and only free at the extremity away from the hinge. This loes not, howerer, alter the function of this door in any way.

It may be that these lower cloors are always attached from below in this way, but it is very difficult to be sure of this, as they readly break away from the surrounding silk, when they appear quite free, as in my clrawing. It was not until I adopted the plan of stufting the tube full of cotton wool before removing the surrounding carth that I detceted this fragile attach. nent.
} 
The nest and spider drawn at figs. A and A 3 of PlateXII. were first discovered by theHonourableMrs. Richard Boyle at Mentone, on March 26th, 1872, and the following is the description of the species kindly prepared by Mr. Pickard-Cambridge :-

Nemesta Eleanora, sp. nov. Plate XII.

Female adult, length 11 to 12 lines.

This spider, which has (like $N$. meridionalis) probably been confused with its near ally $N$. ccementaria, is yet easily distinguished from both by its deeper and richer colouring, as well as by other characters.

The Abdomen has a far more spotted appearance; in some examples a similar series of dark, broken, slightly angular bars is indistinctly visible on the hinder half of the upper side; in others (the more common type) the darker colouring preponderates, and some transverse, broken, slightly angular, or nearly curved bars or lines of pale spots constitute the pattern; the lateral margins of the thorax are not so distinctly yellow as in $N$. meridionalis, and there is a single longitudinal stripe on the caput, of a dull orangeyellow brown, commencing directly behind the eyes and tapering to the thoracic junction; the depression or pit at this point is more strongly marked than in either of the two foregoing species; the ocular area is also smaller, and its transverse diameter is less in proportion to its width; the bristles on the margin of the clypeus, as also those within the ocular area and in the central longitudinal line of the caput, are similarly disposed to those in $N$. meridionalis, but are more numerous; in some details, however, of form and structure-viz., the Labium and Sternum-the present species is more nearly allied to $\lambda$. meridionalis than to $N$.camentaria. The Legs seemed to be rather longer and stronger than in either; the tarsi and metatarsi of the two first pairs, as well as the digital joints of the palpi, are rather densely clothed a little underneath on their onter sides with a kind of fringe or pad of close-set hairs; in other respects the armature of the legs appeared to be similar to that of the other two species, except that in the present one there are three short strong red-brown spines in a longitudinal row on the outer sides of the gemual joints of the third pair ; these spines were plainly visible in all the examples found, but did not exist in any one of those of the two former species. The armature of the 
falces, which are of a uniform yellow-brown colour, is similar to that of those species.

Adult females were found in tubular silk-lined unbranched holes, closed at the orifice with a flat scale-like hinged lid concealed by mosses and lichens, and having a horse-shoe shaped second valve or door less than half way down the tube, of which it serves to shut off the upper part. In this nest, as in that of $N$. meridionalis, the upper part of the tube often projects above the surface of the soil.
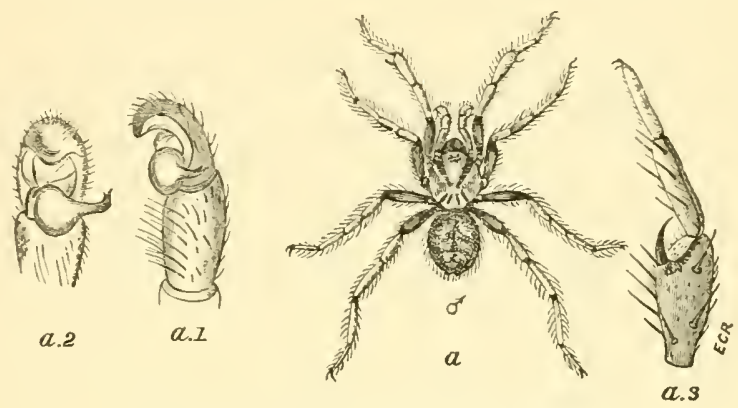

Nemesia Eleanora os Adult, natural size.

Since the above description of the female of this species was written, an example of the adult male has been most opportunely discovered. It is much smaller than the female, its length being only six lines. The Cephalothorax is of an uniform clear yollowbrown colour, tinged with orange, and thinly clothed with a greyish pubescence: the oblique indentations marking the union of the cephalic and thoracic segments are indicated by a strongish blackbrown band on either side, which becomes obsolete as each approaches the other near the central curved indentation; there are also two or three converging suffused blackish stripes on the hinder slope. The relative length of the Legs is the same in both sexes, $4,1,2,3$, but in the male those of the fourth are longer in proportion to those of the third pair than in the female; the spines also on the legs are more numerous and stronger, the upper sides of the femora of all the legs are deeply suffused with black, while in the female this suffusion is not nearly of so marked a character, though the genua of the different females examined had a strong brown-black macula on the outer side of each, while the corresponding maculæ in the single male examined were but just visible; the three spines observed on the outer side of the genua of the third 
pair of legs in the female are of even a more marked character in the male, and hence they may be considered a good and tangible specific difference from other nearly allied species; the tibiæ of the first pair are considerably enlarged on the under side at the fore extremity, where each is armed with a single, longish, strong, slightly curved, pointed black spine directed forwards (fig. $a, 3$ ). The Abdomen is small and of an oval form; its colours and markings resemble those of the female, but on the hinder half of the upper side two or three indistinctly traced pale angular bars or chevrons are formed by the distribution of the black-brown colours and narkings; the under side of the abdomen is of a uniform pale whitish yellow, except the spiracular plates, which are yellow-brown. The Pulpi are moderately long and strong; the radial joint is longer than the cubital, and is of a tumid and somewhat oval form, suffused over most of its surface with dark brown, the rest of the palpus being of a yellowish-brown colonr; the digital joint is small and somewhat oblong-oval, curved downwards, and very slightly concave on its inside; the palpal organs consist of a nearly globular, basal, corneous bult) prolonged into a strongish, curved, but not very long, pearstem form, the stem being distinctly cleft or bifid at its extreme point (vide figs. $a 1$, and a 2), one portion of the bifid part is larger than the other, though both are equal in length, and the stem of the palpal bulb is directed transversely outwards, almost at right angles with the digital joint.

Until the discovery of the male spider now described, and which is, without doubt, the male sex of the female described immediately before, this latter was thought to be the female of Nemesia Mlanderstjernce (Ausserer), and it had indeed been so determined by Professor Ausserer himself. But the form of the palpal organs differs so decidedly from those of $N$. Mandcrstjernce (Ausserer, Beiträge. . . der Territelarice, Verhandl. Z. B. Gesellsch: Wien, 1871 , Bd. xxi. p. 170), that all doubts as to the present being a distinct (and as it is believed to be) a hitherto undescribed species, are removed. From M. Ausserer's description, the pear shaped stem of the palpal bulb in N. Manderstjernoe is comparatively slender, ending in a fine and uncleft point, whereas, in $N$. Eleanora, the stem is strong and its extremity cleft: other differences are also observable in the two spiders, but this one is well marked and the most tangible.

The specific name, Eleanora, now conferred upon the species, is taken from the Christian name of the Hon. Mrs. Boyle, reference 
to whom has been before made, and of whose kind exertions some acknowledgment is thus permanently recorded.

In fig. A, Plate XII., the upper door, which, if closed, would be entirely hidden by the long filmy mosses which surround and cover it, is represented open; but it should be clearly understood that this is artificial and not natural, as in reality these doors close of their own accord by means of their weight and the elasticity of the linge. It will be seen that living mosses of two kinds are worked into the upper surface of this door, which was admirably concealed. (fig. A i, Plate XII.).

It is chiefly in the absence of the branch and the different form of the lower door that the nest of Nemesia Eleanora differs from that of $N$. meridionalis; and, as they inhabit the same localities, it is only when one has dug down as far as the lower door that it can be known to which of the two species the nest belongs. When once this point is reached however, all doubt is at an end; for in this case the unbranched double-door nest differs from the branched in a way which any child could realize, though the respective spiders are not very dissimilar when seen with the naked eye alone. 'This aftords a good instance of the benefit which may accrue to a collector from a study of the habits of the creatures which he collects, for it is certain that it was the nest in this case which first proclaimed the distinctness of its tenant.

Nemesia Eleanora is rather less common at Mentone than $N$. meridionalis, but at Cannes I found the reverse to be the case. At the latter place, on the northern slope of the little hill of St. Cassien, branched 
and unbranched double-door nests may, however, be found in tolerable abundance, the traps being frequently concealed by fallen leaves from the cork oaks, which are woven into their upper surface.

The nest of $N$. Eleanora often has the upper part of the tube prolonged above the surface of the ground and carried up through mosses, grasses, and the like.

An example of this is seen in figs. B and B 1, Plate XII., in which the upper part of the tube is represented with the surface door open in the one case and shut in the other.

The concealment here was so complete that I should never have discovered the nest but for the merest accident. I happened to want some moss to lay with flowers in my botanical tin, and in one handful which I plucked up this trap-door lay concealed. It should be observed that the upper part of the tube and its surface door were covered with growing moss, and this moss must have lived exclusively upon the moisture which the very damp and shady situation afforded, as there was no earth mixed with the silk.

When digging out the nests of $N$. Eleanora, I have frequently seen the lower doors pushed forwards so as to close the tube; and it is my belief that the spider, after having thus barred the passage, puts her back against the door and resists in this way. I must own, however, that, though I believe I have seen the spider in this attitude when I have severed the tube from below, I am not quite certain about it.

$I$ have twice in the months of April and May, and frequently in October and November, found young of this species in the nests with their mother. Usually they were all very small and not larger than that 
represented at fig. B 2, Plate IX., p. 99, but occasionally in October I have found two or three young spiders thrice the size of their companions still in the nest. On one occasion (in April) I found twenty-four small spiders clustered beneath and beside their mother.* I secured the whole family by quickly cutting out the mass of earth containing the lower door on the under side of which they remained cronehed, and brought them hrme alive. I had up to this time been in the habit of killing the spiders by plaeing them in a stopper bottle full of strong spirit of wine, but on treating these spiders in this way I saw reason to regret having done so. I knew that these large spiders, when thrown into spirit of wine, would continue to struggrgle for an hour or more, spasmodieally spreading out their legs as if swimming; but I had supposed that this was only museular motion, and was not in the least aware that the unfortunate creatures were probably conseious all the while. In this instance I first placed the mother spider in the bottle, and then, after the lapse of about ten minutes, when I supposed that the spider, though still struggling, was dead to sense, I dropped in the young spiders. No sooner, however, had I done this than the mother, perceiving them, gathered all her young to her, and, after placing them beneath her, with her legs drawn up round them, as a hen screens her ehiekens with her wings, never stirred again, and retained this attitude until death released her, and the limbs, no longer under

* I have found similar families in October and November in the nests of $N$. meridionalis, only all the young were of nearly uniform size, and very small. On November 21 I dug out a mother spider of this species (meridionalis) with forty-one little ones! 
the control of this wonderful maternal resolution, slackened and fell abroad.**

I need scarcely say that the small spiders were killed by the spirit in a very few instants, but it is almost certain that the mother was alive and conscious for half an hour. Now this pain can easily be spared by placing large spiders for about ten minutes in a closed box with a piece of cotton wool steeped in chloroform beside them, before dropping them into the spirit of wine, a system which I have since that day adopted and found to answer perfectly.

I examined these young spiders carefully, hoping to detect some males among them, but the males, though they differ markedly from the females when adult in their smaller size and curiously-enlarged palpi, do not appear to afford any distinctive mark at this early period. It appeared that these spiders had been but recently hatched, for some among them were still semi-transparent.

I have never found young spiders in the nests of Cteniza fodiens or Nemesia camentaria.

M. de Walckenaer $\uparrow$ quotes a statement made by M. Rossi to the effect that Cteniza fodiens curries its young on her back, as certain species of Lycosa (Tarantula) do. He points out the interest which would attach to this observation if confirmed, as showing a similarity in habit between the two groups, which are otherwise nearly related.

* My own impression is that this act was one of conscious protection on the part of the mother spicler; but Mr. Pickard-Cambridge doubts this, and would attribute the action to the tendency which spiders commonly display to clutch at any material object when dying in this way.

+ Walckenaer (C. A. de), Les Aranéides de France (date?), p. 5. 
Observations of this kind are difficult to make satisfactorily, at least in the case of the trap-door spiders with which I am acquainted, and which appear to be nocturnal in their habits. I have certainly never seen them out of their nests in the daytime, and but rarely detected one of them (Nemesia camentaria) even venturing to peer out of her door set ajar for the purpose.*

The following very singular account is given by MI. Erbert of the habits of Cteniza ariana, which he watched in the island of Tinos. I quote from the abstract given in the Zoological Record cited below :"At night these spiders come out of their nests, fasten the open trap-cloor to neighbouring objects, and spin a net, about six inches long by scarcely half an inch in height. In the morning the nets were removed, and Erber believes that the net of each night is added to the trap-door. He found eggs at the bottom of the tubes, attached singly to threads, to the number of about sixty. The young seem to form dwellings very early."

It would be very interesting to know whether these nocturnal habits are also found in our spiders on the Riviera.

* M. Olivier, however, states (Encyclopédie Méthodique, tom xviii., p. 228, Art. Araignées Mineuses, Paris, 1811 ) that he has twiee founıl nests in the islands off Hyères and on the promontory of St. Tropez the doors of which were set open in the daytime and the tube empty, this seeming to imply that the spiclers were out hunting and were diurnal in their habits. $\mathrm{He}$ did not see the spillers, but from his description the nest was of the cork type. .... Here is an interesting point, and one which those naturalists who make Hyères the field of their observations should endeavour to throw further light upon.

+ In Verhandlungen der k. k. zool. bot. Gesellscluaft in Wien, vol. xviii. pp. 905, 906, quoted in Zoological Record, vol. v. p. 175 (1868); see also Appendix B. 
I have been favoured* with a sight of an unpnblished manuscript by Mr. Hansard giving an account of his observations on Cteniza fodiens, made in Curfu. This gentleman states that some of these spiders which he kept in captivity, used to come out at night, and might sometimes be surprised roaming about the room at a very early hour in the morning. He, however, relates that he had received from a friend an account of a trap-door spider inhabiting the island of Formosa, in the China seas, which constructed nests similar to those of Cteniza fodiens, but which were habitually to be seen outside their nests in the daytime, attracting attention by "staring at" any one who might approach, and then hurrying back to their nests and closing their doors after them.

Lady Parker has also told me of some black trapdoor spiders which were so common about Paramatta, near Sydney, in Australia, that scarcely any one paid attention to them, and which might habitually be seen out on the garden paths in the daytime near their holes, to which they would run in all haste when alarmed. The eye of the passer-by was attracted by the open doors, which were about the size of a sixpence, and fall over backwards when the spider makes her exit, but when closed, on her return, they fit so neatly that it is extremely difficult to detect them.

It will, perhaps, have been observed that I have throughout spoken of the female spider only, scarcely any allusion having been made to the male. The truth is that, though 1 have carefully searched for

* I am indebted to Mr. Moseley for procuring this MS., and to Prof. Rolleston, whose property it is, for permission to make use of it. 
them, I have never been able to secure more than a single male spider." During the winter, spring, and late autumn (October) the female appears to live solitary, in the daytime at least, and the male probably hides in the crevices of old walls and in similar places. I have diligently turned over piles of stone, greatly to the annoyance of many little scorpions, but lave never secured, or even seen, another male spider. This is the more to be regretted as the species of trap-door spider are much better characterized in the male than in the female sex, the bulb-like enlargement which is found at the end of the palpi in the former taking on a great variety of forms, each of which is distinctive.

MI. de Walckenaer† says :-_-"C'est toujours pendant la nuit que ces aranéides travaillent à leurs habitations et courent après leur proie. C'est en Août que la Mygale maçonne (Nemesia-or Mygalecementaria) atteint toute sa grosseur. ..... En Septembre elle devient mère et méchante en même temps ...... les mouches, les moucherons, les petits vers lui servent de pâture; elle les prend dans les filets qu'elle étend et attache sur les inégalités des terres voisines de sa demeure. Elle vit après la ponte en société avec son mâle. Dorthès a vu plusieurs fois, dans la même habitation, le mâle et la femelle avec une trentaine de petits."

Any one, therefore, who has an opportmity of examining the nests during the early autumn, might

* Three days before sending this IIS. to print, and long after the plates had been completed. I captured on Oct. 2:3rd one male of Nemrsia Lleunora. He lay crouched in a crevice in a mossy bank, and had, perhaps, been duiven out of some deeper hiding-place by the heavy rains.

+ Les Aranéides de France, p. 4. 
perhaps, discover the happy families spoken of by M. Dorthès, but which it has never been my good fortune to see. It is not known positively whether the male spider ever assists in the construction of the nest, but, as we know that the female is able to make it without his aid, there seems no reason to suppose that he does.

I have seen the female $N^{\prime}$ emesia meridionalis construct a trap-door in captivity, after having been placed on a flower-pot full of earth in which I had made a cylindrical hole." She quickly disappeared into this hole, and, during the night following the day of her capture, she made a thin web over the aperture, into which she wore any materials which came to hand. The trap-door at this stage resembled a rudely constructed, horizontal, geometrical web, attached by two or three threads to the earth at the mouth of the hole, while in this web were caught the bits of earth, roots, moss, leaves \&c. which the spider had thrown into it from above. After the second night the door appeared nearly of the normal texture and thickness, but in no case would it open completely, and it seemed that the spider was too much disgusted with her quarters to think it worth while to make a perfect door. I believe that when a door is finished the few threads which served as supports and connected it with the earth on either side of the hinge are severed, and this is borne out by the following instance. While I was at work one evening drawing the spider's nest concealed in the plant of ceterach fern (Plate XI., fig. A, p. 105) which I had dug out for the purpose, I detected something

* An account of further experiments with captive spiders will be found in Appendix G. 
moving at the mouth of a tiny hole [just large enough to adınit a crowquill pen] in the mass of earth on the opposite side of the fern to that in which the large trilp-door lay.

The lamp-light fell full upon it, and I soon saw that the moving object was a very small spider, not bigger than that drawn at B $: 2$ in Plate IX., which was at work in the mouth of its tube. Whether Ihad, in removing this mass of earth, destroyed the door I cannot say, but it is certain that the opening of the tube was completely uncovered, and it soon became apparent that the little spider was intent upon remedying this deficiency. After a few threads had been spun from side to side of the tube I watched the spider make one or two hasty sorties, apparently spinning all the while, and finally I saw her gather up an armful, as it were, of earth and lay this on the web. After this the occupant of the tube was concealed, but I could see from the movement of the particles of earth that they were being consolidated, and that the wearing of the under surface of the door was being completed. Next morning I was able to lift up the door, which harl the form of a small cup of silk, in which the earth lay. It was then soft and pliant, but in ten days time it had hardened and become a very fair specimen of a minute cork door (see figs. A 1, A 2, of Plate XI.).

On one occasion a captive Nemesia meridionalis employed some pieces of scarlet braid which I had purposely strewed, along with bits of moss and fragments of leaves, in a circle round the opening of, and about two inches away from, the hole.

It is probable that these spiders have in times past learned by experience that they cannot do better than 
take such materials as come to hand, as these will ordinarily serve for the concealment of their door.

However, these trap-door spiders do seem to exercise some discrimination in the choice of materials; for I have observed several instances in which, when the door of a cork nest has been removed, if the door was originally covered with moss, moss will again be used in its reconstruction, even though the mouth of the tube be then surrounded by bare earth.

Thus, for example, in one case where I had cut out a little clod of mossy earth, about two inches thick and three square on the surface, containing the top of the tube and the moss-covered cork door of $N$. camentaria, I found, on revisiting the place six days later, that a new door had been made, and that the spider had mounted up to fetch moss from the undisturbed bank above, planting it in the earth which formed the crown of the door.* Here the moss actually called the eye to the trap, which lay in the little plain of brown earth made by my digging.

I have seen the same thing happen when the door of $N$. Elcanora has been removed and replaced, moss being again used in the work of reconstruction. Trapdoor spiders in warm weather very quickly replace their trap-doors; and if you pass by a wall where several nests have been robbed of their doors only a week before, they will usually be found quite perfect again.

It has been stated that, if the door of a cork nest

* Mrs. Boyle first called my attention to this curious fact, of which I have since seen many examples. I have purposely removed several cork dorrs from mossy banks in order to observe this point.

$+M$. Dorthès on the Structure and Economy of some Curions Species of Aravea, in Trans. Linu. Soc. (London), II. 88-90. 
be fastened down with a pin, a second door will be found next day by the side of the former one. No doubt spiders not unfrequently find their doors blocked up by a fall of earth, and are thus obliged either to make a new opening or to prolong the old tube.

I once fastened open the surface doors of three of the double-door nests by passing a thread through the silk of the door and tying it back to some twigs above. The doors were thus turned backwards, and the aperture of the tubes, which lay in a vertical terrace wall, exposed to view.

Next day, after a night of very heavy rain, I found the doors as I had left them, but in one nest the lip of the tube had been dragged inwards so as partially to close the tube; in the second nothing appeared to have been done, but in the third nest a new covering had been very cleverly extemporized out of three fallen olive-leaves, which were loosely spun together and attached by one or two threads to the margin of the tube. This formed an admirable concealment, but did not move freely as a door, the web being too imperfect. 'Two days later, however, it was completed and had become a perfect door, moving on a hinge just within and below that of the former door, which still remained as I had fastened it. The other nests remained in the same condition as before, only that a little moss had been dragged into the mouth of the tube of the nest, which hatd been partially closed with its own lip.

The extreme reluctance which these spiders show to abandon their dwellings is curiously exemplified by what follows. 
Certain nests which were furnished with two doors of the cork type were observed by Mr. S. S. Saunders* in the Ionian Islands. The door at the surface of these nests was normal in position and structure, but the lower one was placed at the very bottom of the nest and inverted, so that, though apparently intended to open downwards, it was permanently closed by the surrounding earth. The presence of a carefully constructed door in a situation which forbate the possibility of its ever being opened seemed, indeed, something difficult to account for. However, it occurred to Mr. Saunders that, as these nests were found in the cultivated ground round the roots of olive-trees, they may occasionally have got turned topsy-turvy when the soil was broken up. The spider then, finding her door buried below in the ground and the bottom of the tube at the surface, would have either to seek new quarters or to arlapt the nest to its aitered position, and make an opening and door at the exposed end. In order to try whether one of these spiders would do this Mr. Saunders placed a nest, with its occupant inside, upside down in a flower-pot. After the lapse of ten days a new door was made, exactly as he had conjectured it would be, and the nest presented two doors like those which he had found at first.

There is a specimen of one of these inverted nests, with its two doors, in the British Museum, and this might easily be supposed, at first sight, to be an example of a new kind of double-door nest. On close inspeciion, however, it will be seen that one of the

* Description of a species of Mygale from Ionia in Trans. of Ent. Soc. (London, 1839), III. p. 160. 
two doors is discoloured and partly decayed, this being, no doubt, the one which had been buried beneath in the earth and so rendered useless.

Questions have often been asked as to the manner in which trap-door nests are commenced in the first instance, and whether the weaving of the silk lining is begun at the top or the bottom of the tube.

The structure of the cork door also, which often appears so perfectly turned as to resemble the work of a potter's lathe, is another difficulty.

These questions have, as it seems to me, been neediessly complicated by taking it for granted that the perfect nest of the mature spider is made all at one time, that the tube, perhaps of a foot in length, is excavated, lined, and furnished with a door within some short period of time, such as ten days or a fortnight, perhaps.

On the contrary, I believe that the nests are, as a rule, the result of many successive enlargements, and that the nest of the infant, the tube of which is no bigger than a crowquill, is not abandoned, but becomes that of the full-grown spider. This must require time, but how long, whether months or years, we have yet to learn.

Very little is known at present as to the longevity of spiders, but Mr. Blackwall* says that some live only one year, while others, such as Tegenaria civilis and Segestria senoculata, have been known to live four.

Whether the tran-door spiders are very long lived or not I cannot positively say, but, from the appearance of the growth of moss and lichen on the doors

- Spiders of Great Britain and Ireland, p. 8. 
of some nests which I have observed, I am inclined to think that they must have been inhabited for more than a twelvemonth.

Evidence of the enlargement of the door is not very rare to meet with, though, as a rule, the new piece is woven on to the old with such neatness as more or less to obscure this. In fig. B, Plate X., p. 100, the old and smaller surface-door of a nest of Nemesia meridionalis is seen partially attached to the larger new door, which has been constructed below it; while in fig. $\mathrm{C}$ of the same plate, three doors, or rather three enlargements of one door, may be traced. It is this, I believe, that gives rise to the tiled appearance which these trap-doors sometimes present, and which has caused them to be compared to oyster-shells. Something similar may also be occasionally seen in doors of the cork type, as, for example, in that figured at $\mathrm{A}$ and $\mathrm{A} 1$ in Plate VIII., p. 94, where the old and smaller door is seen partially raised above the surface of the new one. This I imagine to be merely an example of rather clumsy workmanship, as, if I am right, a full-sized cork door usually incloses within itself several lesser doors, which formerly fitted the tube and have had to be enlarged.

This is borne out by the fact that such a door will, on examination, be found to consist of several layers of silk, with more or less earth between each, these layers decreasing in size from without inwards, and together forming a sort of saucer in which the small central mass of earth lies. Thus by moistening a series of the cork doors of Nemesia camentaria, I have been able to detach, in one of medium size, from six to fourteen circular patches of silk, of which the outermost, or that which 
forms the lower surface of the door, is the largest, and the innermost the smallest, the others being intermediate in size as in position. Perhaps if I had had larger doors at $m y$ disposil for examination I might have found more layers, as other authors* speak of a much greater number of layers in the cork doors of Cleniza fodiens. Be this as it may, I an confirmed in my opinion that the layers of silk mark the successive enlargenients of the nest by the additional fuct that in very small doors the layers of silk are few or single, and that a proportion is observable as a rule between the size of the door and the number of layers of which it is composed. $\dagger$

Another proof that enlargement takes place, may at times be found in the nests of $N$. Eleanora, where one, or even two useless doors may be detected behind the lower door.

Now when there are three lower doors in this way the one which is in use is the largest, and the door lying nearest to this one the next in size, while the hindmost is the smallest of all. But though those abandoned doors are now too small to fit the existing tube, they

* M. de Walckenaer seems to have found more than thirty alternate layers of silk and earth in one of the doors of Cteniza fodiens, as we may gather from the following:- "Quoique cette porte n'ait guère que trois lignes d'epaisseur, elle est formée par la sujerposition de plus de trente couches de terre séparées les unes des autres par autant de couches de toile. Toutes ces assises successives s'emboitent les unes dans les autres comme les poids de cuivre à l'usage de nos petites balances. Les couches de toile se terminent au pourtour de la porte." Walckenaer, Histoire des Insectes Aptères (Suites à Buffon), vol. i. p. 238 (Paris, 1837).

I have not found the regular layers of earth and silk of which M. de Walckenaer speaks, the silk layers being usually in contact at their centres and only separated by a little ring of earth interposed between their edges, this earth being thickest towards the circumference of the layers of silk.

+ This may be scen by the comparison of the composition of doors of different sizes, given in Appendix $\mathrm{H}$. 
did so, no doubt, in their day, for they are exact copies in miniature of the ordinary horse-shoe shaped lower doors. The lower door actually in use may sometimes be found to have two separable cases of thick silk enclosing the central mass of earth, and this also, very probably, represents enlargement. In the nests of $N$. meridionalis $I$ have never found any of these abandoned doors behind the one in use, nor should I expect to find any, for if they were present they would permanently obstruct the entrance from the main tube to the branch.

It is clear that it is better economy on the part of the spider to enlarge its nest rather than build a new one each time. If we compare the infant spider and its nest (fig. B, Plate IX., p. 98) with the full-grown creature and its nest (fig. A, Plate IX.), it becomes evident that the growing spider must either construct many nests of intermediate size, or frequently enlarge the original domicile. And we do in fact lind nests of all sizes between the two extremes.

I cannot help thinking that these very small nests, built as they are by minute spiders probably not very long hatched from the egg, must rank among the most marvellous structures of the kind with which we are acquainted. That so young and weak a creature should be able to excavate a tube in the earth many times its own length, and know how to make a perfect miniature of the nest of its parrents, seems to be a fact which has scarcely a parallel in nature.

When we remember how difficult a thing it is for even a trained draughtsman to reduce by eye a complicated drawing or model to a greatly diminished scale, we must own that the performance of this feat 
by a baby spider is so surprising as almost to exceed belief.

And yet even the most complicated form of nestnamely, that of the branched double-door type-is perfectly reproduced in miniature by these tiny architects, with the upper door, lower door, main tube, and branch (fig. B, Plate IX., p. 98).

In order to test whether the doors are enlarged or not I measured the surface doors of seven double-door nests and one minute cork door on April 30th, making a careful plan of the terrace wall in which they lay, in order to make sure of finding them again on my return to Mentone in October.

The following table will show that all were enlarged, the average rate of increase being $1 \frac{7}{10}$ lines in the five and a half months which had elapsed:-

Measured A pril 30, 1872.

No. l. 9 lines across

$\begin{array}{ll}\text { II. } 4 & ,, \\ \text { III. } 4 \frac{1}{2} & ,, \\ \text { IV. } 4 & , \\ \text { V. } 2 & , \\ \text { VI. } 2 \frac{1}{2} & ,, \\ \text { VII. 1 } & ,, \\ \text { VIII. 5 } & ,,\end{array}$

Measured Oct. 18, 1872.

No. I. $10 \frac{1}{2}$ lines across

II. $5 \frac{1}{2}, "$
III. $5 \frac{1}{2}, "$
IV. $4 \frac{1}{2}$,
V. 3 ",
VI. missing
VII. 2 lines across

VIII. $7 \frac{1}{2}$, ,

We can scarcely venture from such limited premises to draw any precise conclusions, but if we suppose that during the entire course of the year the nests increase on an average by about four lines in diameter, and assume that the rate of growth continue the same, the nest of the infant spider, whose surface door measures scarcely a line across, would still require four years to attain the dimensions of some of the largest double-door nests, whose surface doors measure sixteen lines across. 
It seems to be the rule with spiders generally that the offspring should leave the nest and construct dwellings for themselves when very young.

Mr. Blackwall,* speaking of British spiders, says :"Complicated as the processes are by which these symmetrical nets are produced, nevertheless young spiders, acting under the influence of instinctive impulse, display, even in their first attempts to fibricate them, as consummate skill as the most experienced individuals."

Again, Mr. F. Pollockt relates of the young of Epeira aurelia, which he observed in Madeira, that when seven weeks old they made a web the size of a penny, and that these nets have the same beautiful symmetry as those of the full-grown spider. Those of the latter are vertical, circular, made of about 250 feet of thread, having about 35 radial lines and $3 \mathrm{~S}$ concentric circles, the outermost of which is some 20 inches in diameter. After the lapse of a day or two the web loses its adhesive property and a new one is made. In about six months the female Epeira has completed her ten changes of skin, one of which takes place in the cocoon, and "at the end of eight months the spider is $2 \pi 00$ times as heavy as at its birth." This Epeiralives, we are told, for about eighteen montlıs.

One can scarcely contemplate the work of these architects and weavers, and especially of the trap-door makers, without being carried away into the whirlpool of discussion which has so long raged round the word instinct.

* Loc. cit., p. 11.

+ The History and Habits of Epeira aurelia, in Annals and Mag of Nat. Hist. for June, 1865. 
Do the young spiders build their first nest by instinct-that is to say, independently of all teaching or personal experience-or do they copy the nests in which they were hatched?

What is wanting, however, is not discussion, of which we have had enough, but demonstration, and demonstration is hard to come by, depending as it must upon careful and repeated experiment.

If it were practicable, and I have no reason to know that it is not, to rear spiders from the egg away from the nest, and then to cause them to build in places where they should be perfectly at home and yet cut off from all communication with their kind, we might hope to learn whether they can construct the characteristic nests of their species without ever having seen one.

Mr. Wallace* shows that there is some reason to doubt whether birds, which are so frequently said to build by instinct, would, under parallel circumstances, construct the nest proper to their kind; and he states that birds brought up from the egg in cages do not do so, nor do they even sing their parents' song without being taught.

Of course we can scarcely compare birds and spiders together, but we should hesitate, in view of $\mathrm{Mr}$. Wallace's expressed opinion as to the nest-building habits of the former, to assume that the latter are independent of teaching and personal experience. It may very possibly be so, but it has never been proved. I have endeavoured to gather together all the pub-

* Chapters on Instinct and on the Philosophy of Birds' Nests, in his Con. tributions to the Theory of Natural Selection. 
lished records of the nests of spiders belonging to the sub-order Territelaria, with a view, if possible, to trace out the geographical range of the several types of structure. I have, however, met with but a small amount of success, and even among the limited number of tolerably complete accounts of nests which I have been able to discover, several made no mention of the spider to which the nest belongs.

Prof. Ausserer* has enumerated 215 species of Territelaria as having been found in the world at large, but of this large number ten only, as far as I have been able to learn, have been described in connexion with their nests, and eight of these belong to the Mediterranean region. $\dagger$ To these we may now add two more, namely, Nemesia meridionalis, with its branched double-door nest, and $N$. Eleanora the builder of the unbranched double-door nest, thus making twelve in all.

Three of the twelve, however, Atypus piceus, $A$. Blackwallii, and Nemesia cellicola, ${ }_{\ddagger}^{\ddagger}$ do not appear to build true trap-doors, but only a simple silk tube without any covering at the mouth.

The following tabular view will show to which of the four types of trap-door nest those of the remaining nine spiders belong, and their geographical distribution :-

* In his monograph of Territelarice quoted above.

* I use this term in its widest sense, making it even include Morocco. A list of the species known to inhabit this region will be found in Appendix C.

¥ See Appendix A, p. 141 . 
TRAP-DOOR SPIDERS WHICH BUILD

\begin{tabular}{|c|c|c|c|}
\hline Nests of the cork type. & $\begin{array}{c}\text { Nests of the sin- } \\
\text { gle-door wafer } \\
\text { type. }\end{array}$ & $\begin{array}{l}\text { Nests of the } \\
\text { double-door } \\
\text { branched type. }\end{array}$ & $\begin{array}{c}\text { Nests of the } \\
\text { do'able-door } \\
\text { unbranched type. }\end{array}$ \\
\hline $\begin{array}{l}\text { Idiops syriacus, Beirût. } \\
\text { Cteniza fodiens (Ct. Suuvagei), Cor- } \\
\text { sica, Pisa, Mentone. } \\
\text { Ct. cedificatoria, Tangiers. } \\
\text { Ct. (Cyrtocarenum) ionicum, } \\
\text { Ionian Islands. } \\
\text { Ct. (Cyrtocarenum)Ariana, Naxos, } \\
\text { Tinos. } \\
\text { Nemesia ccementaria, South of } \\
\text { France, Spain, Sardinia, Cor- } \\
\text { sica, Sicily, Algiers, and the } \\
\text { var. germanica from Wippach, } \\
\text { near Görz. } \\
\text { [Nests, apparently of the true } \\
\text { cork type, hare also been } \\
\text { found in Australia, New Gra- } \\
\text { nada, India, and the island of } \\
\text { Formosa, but their nccupants } \\
\text { are unknown.] }\end{array}$ & $\begin{array}{l}\text { Cteniza nidu- } \\
\text { lans, West } \\
\text { Indies (and } \\
\text { South Ame- } \\
\text { rica?) }\end{array}$ & $\begin{array}{l}\text { Nemesia } \\
\text { meridionalis, } \\
\text { Mentone, } \\
\text { Cannes, and } \\
\text { Sestri, uear } \\
\text { Genoa. }\end{array}$ & $\begin{array}{l}\text { Nemesia } \\
\text { Elcanora. } \\
\text { Mentone, and } \\
\text { Cannes. }\end{array}$ \\
\hline
\end{tabular}

As far, therefore, as I know at present, the cork type of nest is the only one which is widely spread, and which is constructed by spiders of more than one species. For, while the single-door wafer, and the branched and unbranched double-door nests are each the work of one particular spider, we see that nests of the cork type are made by spiders of six distinct species, belonging to at least three genera.

It is almost certain that a much larger number of spiders of different kinds, though all probably members of the sub-order Teritelaria, construct nests of the cork type, for descriptions and specimens of trapdoors of this kind are brought from the most distant parts of the globe. It is true that these specimens and descriptions usually only show us the surfacedoor, but as far as our present knowledge goes, we 
are led to suppose that a door of the cork type is always associated with a simple tube, in which there is no trace of a second door or valve, so that, judging of the unknown by the known, we conclude that nests which possess the characteristic peculiarity of a true cork door are true cork nests in other respects also. Further research may possibly show that there are exceptions to this generalization, but I do not at present know of any.

I have seen Australian specimens of large trapdoors, of the cork type, measuring from one to two inches across. In some of these the doors were scarcely more than semicircular but very thick, and having their edges bevelled so as to correspond with the sloping margin of the tube; ; in others, found at Paramatta, and described to me by Lady Parker as being tenanted by a black spider, the doors were said to be circular and much smaller, scarcely larger than a sixpence, and of the cork type.

The upper portion of a nest from New Granada has been figured and described by M. Victor Audouin, $\uparrow$ which closely resembles that drawn at Fig. $\mathrm{A}$ in Plate VII., p. 88, but the door is about a third larger.

I have also been assured that nests of the cork type are found in many parts of India, and we have seen above that they are reported to be common in the island of Formosa.

Putting all this together, it will be seen that nests of this type are found all round the globe; in Formosa, India, Syria, the Grecian Archipelago, Italy

- Specimens of Australian nests may be seen in the cases at the British Museum.

† Note sur la demeure d'une araignée maçonne de l'Amérique du Sud, Annales des Sciences Naturelles (Zoologie), tom. vii. tab. 3, p. 227-231. 
and the adjacent islands, Trieste, South France, Spain, Morocco, New Granada, and Australia; while the single-door wafer nest is only known at present in the West India islands; * the branched double-door nest at Mentone, Cannes, and Pegli near Genoa, and [doubtfully] near Naples and in Ischia; and the unbranched double-door type at Mentone and Cannes alone. It is quite probable that these three latter forms of nest will some day be found to have a much wider range than that assigned to them here, but I can scarcely think it likely that they will ever be shown to claim the world-ivide distribution of the cork type. Supposing that these nests are eventually discovered in many widely distant localities, a very interesting question will arise as to the specific characters of the spiders which inhabit and construct them. Shall we then find, for example, that nests of the unbranched double-door type are not tenanted and fabricated by Nemesia Eleanora alone, as we have hitherto found to be the case, but by many other distinct species also, each in its peculiar district?

That is to say, will the type of nest remain the same while the occupants vary, as in the cork nests?

If, on the other hand, we learn that these three types, the single-door wafer, the branched and unbranched double-door nests, are very local, we shall be led to inquire into the probable causes of this limitation.

But we must study much more closely the habits of

* There is a nest exhibited in the Museum collection at the Jardin des Plantes at Paris, marked "Amérique du Sud," which is perhaps of this type. 
these trap-door spiders, and the difficulties and dangers to which they are exposed, if we wish to appreciate fully the true meaning and intention of the structure of their nests, and to find the clue to the difficult question why one type should be more frequently adopted than another. Above all, we must discover what are their enemies, and how and when they are most exposed to them. MI. de Walckenaer gives an entertaining account* of the enemies to which spiders generally are exposed, and of this the following list is an abstract.

Many kinds of monkeys, squirrels, and several sorts of birds, as well as lizards, tortoises, frogs, and toads prey upon spiders. A species of black sheep, found in the steppes of Asiatic Russia, unearths the tarantulas (Lycosa), and eats them. ("Une espèce de brebis noire, dans les steppes de la Pussie asiatique, déterre les tarentules et les mange"). In the East India Archipelago there is an entire genus of birds of the passerine order, which have been named "Alachnoptères" because the different species of which it is composed live exclusively on spiders. Besides these, the centipede (Scolopendra), and the following Hymenopterous insects, Plilanthes, Spleex, Pompilus, Pimpla Ovivora, and $P$. Arachnitor [which last lay their eggs in the eggs of spiders], carry on perpetual hostilities against them.

I have seen it stated that ants are among the worst enemies of spiders, driving their galleries through the silk tubes of the latter and devouring their eggs. Of this I have never seen any trace, and, on the contrary,

† Histoire des Insectes Aptères (Suites à Buffon), vol. i. p. 172-7. 
have on four occasions found the remains of ants' bodies at the bottom of the trap-door spiders' nests.

I have but seldom detected any refuse in these nests, and this accords with what M. Erber tells us* of the care with which Cteniza Ariana, which he watched by moonlight in the island of Tinos, carried away the empty bodies of the beetles, the juices of which had been sucked out, to a distance of some feet from its hole. In October, 1572, however, I found a black layer of débris at the bottom of five nests of Nemesia Eleanora, and this was composed principally of the remains of insects, and among others of some rather large beetles.

As far as I am aware, M. Erber is the only naturalist who has ever placed any detailed observations on record as to the nocturnal habits of a trap-door spider in its native haunts; and we may learn from him how we should watch these creatures, if we wish to discover the manner in which they take their prey, and of what their prey consists.

$\mathrm{He}$ relates how he witnessed the capture, in the long low snare which Cteniza Ariana spreads close to the ground, of two strong, night-flying beetles (Pimelia and Cephalostenus), and how these were at once devoured, and their horny coats thrown away.

More observations of this kind are greatly wanted, as it is most important that we should know what are the principal sources of food upon which these spiders depend for their existence.

If we could answer the questions, what do they eat?

* A translation of these very interesting observations will be found below in Appendix $B$. 
and what do they fear? we should have advanced a long way towards resolving the larger problem as to the causes which limit particular species to certain districts.

I greatly envy those who are able to travel, and who have it in their power to investigate the habits of these creatures at several widely separated points; for there seems every probability that other new types of nest remain to be detected in warm climates, some of which may perhaps exceed those we have been here studying in beauty of workmanship and adaptation; it is at least certain that an abundant harvest of interesting facts in the life history of trap-door spiders remains yet to be gathered in.

Indeed it appears to me that we are only on the threshold of discoveries of this kind, and that the materials brought together in the preceding pages may be considered as but a small simple of what may be collected on the outermost edge of this great domain.

I shall be satisfied if I have been able in the present little work, to hold the door sufficiently ajar to permit those who love nature and her ways to catch a glimpse of the wonders and beauties of the untrodden land that lies beyond. 


\section{A P P E N D IX.}

\section{A.}

Nemesia (Mygale) meridionalis, Costa.*

" MI. fusco rufoque-flavicante, maculis obscurioribus, thorace radiatim, abdomine seriatim dispositis, subtus thorace rufescente, abdomine flavidulo, mandibulis spinarum serie unica, tarsis omnibus spinulosis."

"The cephalo-thorax oval, elongated and truncate in front, while the head is smooth and bare, with a group of eight eyes, a little keeled in the middle; of a fulvous-brown colour, with ten rather dusky spots arranged in rays, and corresponding to the direction of the eight legs (anche) and the two maxillæ. The mandibles are large, horizontal at first, then curved downwards, making a quarter of a circle, furnished with numerous hairs, especially on the inner side, and at the anterior extremity above there are mobile and rather long spines; below they are channelled, with six little teeth or spines on the edge (rilievo) of the inner face, clothed with many bristling hairs, with which the outside is also covered, but without any teeth; on the imer face they are flattened, so that they fit perfectly close. The fang is strong, curved, acute, and black. The maxillæ are clothed with brown hairs almost as the legs are, and at their extremity, on the outer side, stand the long palpi, rather hairy (pelaccinti), terminated by a very short and simple little claw. The sternal lip is very small and round. The abdomen oval, longer or shorter according to age, dusky ash in colour, spotted with

* Costa, Fauna del Regno di Napoli, Aracnidi (1861), p. 14, tab. i. figs. 1-4. [Translation.] 
brown, and covered with short and depressed (rasicci) hairs. The brown spots are disposed in slanting lines, placed obliquely to the median line, which is also brown; below it is somewhat lighter, and becomes slightly yellow, increasingly so in the female as pregnancy advances. The pulmonal sacs are always pale yellow, and involved in the fold (tramezzati dalla ripiegatura). Between these, and within the fold itself, the female sexual organ opens, consisting of a transverse opening invisible to the naked eye, but clearly seen on using a lens and removing the fold under which it is concealed, by means of the point of a scalpel or of a pin. The posterior extremity of the anus presents four spinnerets, of which the two upper are much the longer, and composed of four easily seen joints, the lower very short. The feet are moderate, and the longest are of the length of the entire body when this is fully developed (quando è perfettamente sviluppato); of these the fourth pair are about a third longer than the first, the third of about the same length as the second, which is the shortest of all. The tarsi of these are armed with two small curved claws, and the third and fourth joint with many long, delicate, straight, and mobile spines, which in the first pair become fewer as they approach the last joint. The eyes are arranged in three lines, as they are represented in $\mathrm{C}$, Plate I., Fig. 3, and of these the two last of the posterior line are white and glistening, the others brown.

"Our Mygale lives in tubular cavities, or burrows, which she excavates for herself in loose and friable soil, in walls made of volcanic earth, in shady places, and for the most part turned to the north or to the west, seldom to the south-hence cool and rather damp. The burrows do not exceed the length of a palm, eight lines at their widest part. For about the length of an inch the tube is funnel shaped, thence it continues of a nearly uniform magnitude. Its first direction is almost horizontal, then it rises continually, turning to the right or left, and sometimes makes zigzags. As the tubes are excavated in friable soil, she takes care to tapestry them inside with the same glutinous material of which the other races make their web, by means of which the burrows are made smooth on the inside, and to strengthen them in 
such a manner that even when the outer eartly part has become cracked, or been torn away by the action of the rain, they remain firm and fit to conceal their inhabitant. I have often found the tubes of web thus left exposed, as they are represented in Plate I., Fig. 4, situated in the cement of a wall, and among Lycopodium denticulatum, Adiantum Capillus-Veneris, Marchantia polymorpha, and other small plants. And it seems that the animal, perceiving the nature of the soil, takes care to reinforce the silken case, so much the more as she finds the earth less firm, and rice versâ. So that in burrows excavated in solid ground, with the exception of a little space close to the aperture, the nest is merely smoothed and daubed; while sometimes the spider constructs a tube so strong that it supports itself even when deprived of all the earth, the animal having had the foresight to attach it along the course of the clefts of the rock, or to the cement of the pieces of tufa in the wall, as represented in Plate I. They have often also a double aperture, and the upper portions of the burrows converging, meet and anastomose at about two inches distance. The aperture is closed by a little door or valve $(a)$, which, having its hinge in the upper part and a little on one side, falls by its own weight, and fits itself exactly to the opening. The outer surface of the wicket is covered with earth, cemented by the glne of the spider, so that it is rendered imperceptible to common eyes, and the industrious little creature takes care to leave around the aperture a kind of rim, to which the door fitting closely, leaves no passage for any animal, nor does it show its edges. At the bottom of its tube the creature keeps her numerous offspring, and always stands herself as sentinel at the door, holding the wicket raised by means of the four anterior feet, and the palpi, curved extremities of which she inserts between the rim of the tube and of the door, as represented in $a^{\prime} f$. Sometimes, however, they do not appear, but she leaves only the chink for observation, as one sees in $a$ of the same figure. Fig. 2, at $c$, represents the aperture of an abandoned burrow, and at $d$ the raised door of another burrow, with its almost funnel-shaped aperture. That which Sauvage, Olivier, and Latreille relate of her is not true-namely, that she remains at the bottom of 
the burrow, and $\mathbf{r}$ uns to the door only when she sees it threatened, in order to keep the door firmly closed. On the contrary, always standing at the door as sentinel, she leaves it as soon as she thinks it in danger, so that it can be raised without the least effort: but if you hold it a little raised without making any sign of movement, she turns on her back, and comes out to draw it down with her feet, making all the efforts she can to conquer the obstacle. But if you take it away entirely, she turns down the edges to close the aperture as best she can, and that she does hurriedly, without waiting for night. The light seerns to offend her so much that, if exposed to the full day, she remains so stupefied as to appear dead, nor does she move even if shaken; on the contrary, she constantly stops still and holds herself with her feet pressed against her boly. At last, if very much disturbed, she runs quickly for some distance, till she finds a place in which to hide her head, and from thence she does not stir. I have observed that the burrows are always short when the aperture is small, and increase in length as they augment in diameter, which makes me conclude that it is not true that they begin their excavations from the base of the mother's tube, where I have nover found any communication with others. This spider is found in the neighbourhood of Naples (ne' contorni della Capitale), on the Camaldoli, in the island of Ischia, where it lives near the sources of miveral waters, in Gaeta at the foot of the olive trees, among the stones in the ground, \&c. \&c.

"Observation. The difference which distinguishes our $M y$ gale from the Sauragesii consists, first, in the toothing of the mandibles, which is observable on one side only of the channel, and not on both; secondly, in the tarsi all equally armed with spines, and not only the four anterior ones; thirdly, in the colour of the thorax and the abdomen, which is not uniform as is usual in the Sauvageszi. Nevertheless, such differences might be in part climatic, which would cause our Mygale to be considered as a mere variety of the same species, and the others might be the result of the different method of examining the parts, and of the goodness of the instruments." 
At p. 19, in the Fauna del Regno di Napoli, M. Costa gives the following account of the nest of Nemesia cellicola, which he discovered above San Martino in September, 1833 :

"Vive entro la polvere arida, nelle cavità oscure delle muraglie, e propriamente nelle così dette Saettiere, ove, col glutine suo, si costruisce un tubodelicato e mobile, che ha cura di affidare nel suo origine a qualche corpo stabile nel fondo del muro, e che in terra nella polvere, aprendosi l'altro estremo sul piano inclinato dalla polvere stessa costituto."

This, with the exception of the words "e che in terra nella polvere," which are unintelligible to me as they stand, and appear to want a verb, may be translated as follows:-

"She lives in the dry dust, in the obscure crevices of walls, and especially in those which are called Saettiere (loop-holed walls? ?), where she coustructs a delicate and flexible tube with her viscid secretion, and which she takes care to fasten at its commencement to some solid body at the bottom of the wall, ...... the other extremity opening on the inclined plane formed by the dust itself."

We may remark that there is here no mention of any door or concealment at the mouth of the tube, and in this and some other respects the nest of Nemesia cellicola would appear to resemble the nest of Atypus piceus from the neighbourhood of Paris. See above in the text, p. 78.

\section{B.}

On the Habits of Cteniza Ariana.

The following is a free translation of an account read by M.Erber before the Botanico Zoological Association of Vienna,* of the very curious observations which he made on Cteniza Ariana when travelling in the Grecian Archipelago.

"On my return voyage [from Rhodes], I stayed for a fortniglit in the island of Tinos, and, among other things, I cap-

* Verhand. der k. k. zoologisch-botanischer Verein in Wien, vol. xviii. (1868), p. 205. 
tured several specimens of the so-called trap-door spider (Deckelspinne)Cteniza Ariana, Walck., and with much trouble procured an entire tube and trap-door of this creature. . . . . I am thus enabled to exhibit to this honourable assembly the complete nest of this creature, and the spider herself, with her eggs, preserved in alcohol, and can moreover add some few words as to her habits.

"It needs some practice, as the specimen before you shows, to enable one to discover the nest, as the door is always closed by day. I dug out several of these tubes, but failed to find either the remains of food or excrement. So there was nothing for it but to devote a couple of nights to watch these creatures. With this view I selected a place where many spiders had excavated their tunnels, and availed myself of a moonlight night for my observations.

"Shortly after nine o'clock the doors opened and the spiders came out, fastened back the trap-doors by means of threads to neighbouring blades of grass or little stones, then spun a snare about six inches long by half an inch high, and afterwards returned quietly to their holes.

"I had so chosen my position that I could see three of these spiders at the same time. I now captured a specimen and put it into spirits, and in a short time saw entangled in the net of one of the remaining spiders a Pimelia, and of the other a Cephalostenus, both rather hard-lived, night-flying beetles, which were seized by the spiders, and the latter, after sucking out the juices, carried the empty bodies to a distance of several feet from their holes. All these events happened in about three hours, after which time I allowed the two spiders to remain undisturbed, and returned to the house.

" Early next moruing I revisited the spot, and then perceived that these two spiders had entirely removed the net which they made the preceding night, but the entrance to the nest of the spider which I had captured still remainer open, and I could clearly trace the shape of its snare, on which the heavy morning's dew lay. The upper threads were isolated, but the snare became thicker as it approached the ground. I found that these snares had, strange to relate, been gathered up by the two other spiders, fastened on to the door, and smoothly 
spun over, and, on making a vertical section of the doors, which were nearly a quarter of an inch thick, I discovered that they were composed of several layers.

"In the nests of several females I found eggs at the bottom of the tube, not placed in cocoons, but attached by separate threads. The young spiders when hatched are turned out from the asylum of their mother's nest; and I found these creatures when scarcely two lines long already established in nests three inches deep, and furnished with perfect trap-doors, of which facts the specimens I now lay before you are the evidence."

\section{C.}

Species of Territelariæ, enumerated by Professor Ausserer,** belonging to Europe and the Mediterranean region, with synonyms, and two species which I have added in brackets:Atypus piceus, Sulzer.(A. S'ulzeri, Latr.). Holland, France, Switzerland, Germany, Northern Italy.

A. Blackwallii, Auss. England.

A. Anachoreta, L. Koch. Finme.

Idiops Syriacus, Cambr. Beirût.

Apycephalus brevidens, Doleschall. Sicily.

Cteniza Sauvagei, Rossi. (Ct. fodiens), Corsica, Pisa, Mentone, Ionian Islands.

Ct. orientulis, Auss. Brussa.

Ct. cedificatoria, Westw. (Actinopus cedificatorius, Westw.) Tangiers.

Ct. algeriana, Luc. Algiers.

Cyrtocarenum Arianum, Walck. (Mygale (Cteniza) Ariana, Walck.). Naxos, Tinos.

C. tigrinum, L. Koch. Syra.

C. grajum, C. Koch. Nauplia in the Norea.

C. ionicum, Saunders. Ionia.

C. lapidarium, Luc. Crete.

* Beiträge zur Kenntniss der Arachniden-Familie der Territelariæ, in k. k. zool.-bot. Gesellschaft in Wien (1871), vol. xxi. pp. 117.224. 
Cyrtauchenius Walckenaerii, Luc. Algiers.

C. Doleschallii, Auss, Sicily.

C. similis, L. Koch. Saragossa.

C. obscurus, Auss. Sicily.

Nemesia camentaria, Latr. S. France, Spain, Sardinia, Corsica, Sicily, Algiers.

N. ccementaria, var. germanica, Auss. Wippach, near Görz in Trieste.

[N. meridionalis, Costa. Naples, Ischia, Sestri near Genoa, Mentone, and Cannes.]

[N. Eleanora. Mentone and Cannes.]

$N$. cellicola, Sav. et Aud. Rome, Sicily, and Egypt.

N. maculatipes, Doleschall. Sardinia.

$N$. badia. Auss. Corsica.

$N$. manderstjernce, L. Koch. Nice.

$N$. hispanica, L. Koch. Madrid.

N. macrocephala, Auss. Palermo.

Brachythele icterina, C. Koch. Greece.

$B$. incerta, Auss. Brussa.

Macrothele calpetana, Walck. Southern Spain.

M. luctuosa, Luc. Southern Spain.

Leptopelma transalpina, Doleschall. Friuli.

Ischnocolos triangulifer, Doleschall. Sicily.

I. holosericeus, L. Koch. Spain.

I. gracilis, Auss. Cyprus.

I. syriacus, Auss. Syria.

Choetopelma agyptiaca, Dol. Egypt.

D.

Hints on Collecting Spiders.

It is very important to collect adult specimens of males and females, but the former, from their roaming habits, are often extremely difficult to find.

At night they may sometimes be taken by lamplight near the nests of the females, and certain kinds are said to 
live with the female during the months of September and October. The females may usually be found in their nests during the daytime (always in Europe?).

Large spiders should be killed, or at least stupefied with chloroform, before being put into spirit of wine. It is convenient to place the specimens in glass test-tubes closed with corks, and filled with pure spirit of wine, as they may then be examined through the glass.

When specimens of more than one species are placed in the same tube or bottle, it is well to distinguish each by a number written in pencil on a small strip of card fastened round the body witl a slip-noose of thread.

The patterns on the abdomen and cephalo-thorax of the spiders are seen very distinctly when the spiders are immersed in spirits of wine, and these frequently afford characters which aid in determining the species.

M. Thorell, in the introduction to his work On European Spiders, ${ }^{*}$ gives a detailed account of a method by which specimens may be prepared for mounting in cabinets, by drying them within a glass tube held over a flame, but it would appear that, for purposes of study, specimens preserved in spirit of wine are far preferable.

It is very desirable to obtain characteristic portions of, or if possible entire nests, but where the tubes are long, this is extremely difficult to do satisfactorily.

Some nests, preserved in the British Museum, have been coated with thin glue, and this appears to be of some use in binding the parts together. I find that by stuffing the tube full of cotton-wool, before attempting to remove the earth, the nest may sometimes be obtained in tolerably good condition.

* Thorell (T.), On European Spiders, in Nora Acta Regriæ Societ. Scientiar. [psaliensis, ser. 3, vol. viii. fasc. I. et II. (U [isala, 1871). 


\section{E.}

The Nest of the Tarantula (Lycosa T'arentula).

As it is of some interest to compare the burrow of the Tarantula with the nest of its near allies the trap-door spiders, I give the following résumé of M. Dufour's observations:*

"Lycosa Tarentula forms a cylindrical burrow in the earth, often more than a foot long, and about one inch in diameter. At about four or five inches below the surface the perpendicular tube is bent horizontally, and it is at this angle that the Tarantula watches for the approach of enemies or prey.

"The external orifice of the burrow of the Tarantula is ordinarily surmounted by a separately constructed tube, and which authors have not hitherto mentioned; this tube, a true piece of architecture, rises to about an inch above the surface of the ground, and is sometimes as much as two inches in diameter, being thus larger than the burrow itself. This tube is principally composed of fragments of wood fastened together with clayey earth, and so artistically disposed one above the other that they form a scaffolding having the shape of an upright column, of which the interior is a hollow cylinder."

M. Dufour observes, however, that the exterior tube was not found in all the nests. In every case the tube was lined with silk throughout its whole length.

\section{Fi.}

The following description is that given by Prof. Ausserer in his monograph of Territelarice, $\dagger$ of a male trap-door spider which was found at Nice, and named by Herr L. Koch

* Quoted by M. Lncas, in his Histoire Nat. des Animaux Crustacés et Arachnides, p. 357.

† Beitruge zur Kenntniss der Arachniden-Familie der Territelariæ, in Verhand. der k. k. zool.-bot. Gesellschaft in Wien (1871), vol, xxi. p. 170. 
Nemesic IIanderstjernce. It is just possible, I think, that this male may in reality belong to $N$. meridionalis [CostaCambr.], of which the female alone is at present known.* If this is the case, then the name Manderstjernce will have to be suppressed in favour of that of meridionalis. If not, we have yet to discover the female spider and nest of another species of Nemesia!

\section{Nemesia Manderstjerna, L. Koch.}

t Die genaue Beschreibung dieser hübschen Art ihrem Autor, Herrn Dr. L. Koch überlassend, führen wir hier nur jene wesentlichen Unterscheidungsmerkmale an, welche diese Species von den verwandten auszeichnen.-Cephalothorax schön gerundet mit schmalem, mässig hohem Kopfe.-Augenhügel hoch, nach vorn und hinten steil abfallend.-Die vordere und hintere Augenreihe bilden 2 nahezu parallele Curven, mit der Concavität nach vorn. Vordere Mittelaugen stehen so hoch, dass eine Gerade von ihrer Basis zu den Seitenaugen gezogen etwas iiber denselben zu stehen käme, zugleich sind sie von einander um ihren Radius und kaum weiter von den vorderen Seitenaugen entfernt. Augen der vorderen Reihe fast doppelt so gross als die der hinteren.Ziihne des Rechens lang und spitz.-Palpen müssig lang, letztes und vorletztes Glied ähnlich bewaffinet wie bei $N$. cellicola.†-Bulbus birnförmig, mit etwas kurzer, dünner Spitze. - Alle Tarsen der Beine, ebenso Metatarsus I und II mit dünner Scopula, zugleich sind die Tarsen wehrlos.-Tibia 1 keilförmig verdickt, unten an der Spitze ein starker nach oben und innen gebogener, spitzer Zahn, vor demselben ein oben gerade abgestutzter Höcker,-Schenkel oben und innen mit dunkelın Längsstreifen.-Cephalothorax $6 \cdot{ }^{\mathrm{mm}}$.

Nizza.

* Mr. Pickard-Cambridge regards this suggestion (that N. Manderstjernce may be the male of $N$. meridionalis) not improbable.

* Description of palpi of $N$. cellicolu, p. 168: "Palpen kurz, stark. Femuralglied oben bestachelt; rorletztes Glied oben an der Spitze mit 4 starken, etwas kurzen Stacheln, auch das Endglied nach oben mit selir kleinen Stacheln bewaffnet. Bulbus kmz lirnförming, in eine feine, mässiglange, fadendunne (voru nicht gespaltene) Spitze anslanfend." 
Of this description the following is, I hope, a tolerably correct translation :-

\section{Nemesia MTanderstjerna, L. Koch.}

f Passing over the precise description of this pretty species by its author, Herr Dr. L. Koch, let us note here some of the essential characters which distinguish this species from its relations. Cephalothorax fairly (schön) rounded, with small, moderately prominent head. Eye eminence (Augenhügel) prominent, steeply inclined in front and behind. The front and rear row of eyes form two nearly parallel curves with the concavity in front. The foremost central eyes stand so high that a line (eine Gerade) drawn from their base to the lateral eyes would pass just above them, although they are not separated from the lateral eyes by a distance greater thin that of their own radius. Eyes of front row almost twice as large as thuse of hiud row. Teeth of rake (Rechens) long and sharp. Palpi moderately long, the last and penultimate joint armed as in $N$. cellicola.* Bulb pear-shaped, with a rather shorter, more slender point. All the tarsi of the legs, and even the metatarsi I and II, with a slender scopula, although the tarsi are unarmed. Tibia I enlarged into a wedge-shape, (having) beneath the apex a stout pointed tooth bent upwards and inwards, in front of which (is) a truncated prominence (ein oben gerade abgestutzter Höcker). Femur (Schenkel) (having) dusky longitudinal stripes above within.Cephalothorax $6 \cdot 5^{\mathrm{mm}}$.

Nice.

\section{G.}

On Nemesia meridionalis and $N$. Eleanora, Captive in Company with their Joung.

I have tried the experiment of keeping specimens of Nemesic meridionalis and $N$. Elecenora captive iu flower-

* Deseription of palpi of L. cellicola:-Palpi, short, strong. Femoral joint fnruislied with spines above; pemultimate joint armed with four stout rather short spines above the apex, the terninal joint also having some rery small spines. Bulb shortly pear-shaped, running out into a fine, moderately long loint, which is slender as a thread, and not split in front. 
pots, partly filled with earth and covered with gauze, but I have never been able to detect the least inclination on the part of either of these spiders to excavate a burrow in the earth.

Thinking that I might have better success if I were to place the mother spiders, together with their young, in captivity, I captured a female $N$. meridionalis and $N$. Eleanora, each with its brood, and placed them on moist earth in flower-pots under gauze. The result, however, was that the young spiders concealed themselves in the crevices of the soil, while the mother spiders remained exposed.

The adult $N$. meridionalis lived thus for twenty days (from the 7 th to the 27 th of November), capturing and killing flies with which I supplied her, but she then suddenly died.

After seventeen days' captivity the other species ( $N$. Eleanora) began to cover a small surface of the gauze with a semi-transparent substance (which resembled varnish rather than silk), secreted from its spinners, and four days later it began to weave a cell; this cell took twelve days to complete, and finally assumed the shape of a rudely-formed figure of 8 , with a circular aperture at either end, each of which was kept open during the construction of the cell, and then closed. The gauze itșelf, covered with silk, formed the ceiling of the cell, while the floor was made of silk attached to the earth, and the sides of strong and rather opaque silk.

This cell bore no resemblance to any portion of any trapdoor nest that $I$ have ever seen, and it is difficult to conceive how the idea of such a structure presented itself to the spider. Its outline indeed had some likeness to the general outline of the spider herself, one loop of the figure 8 being rather smaller than the other. The distance between the floor and the ceiling of this impromptu cell was a little over half an inch, its width varying from one inch in the broadest to eight lines in the narrowest part, while its length was an inch and a quarter.

It would appear that the object which the spider had in view was to construct a warm and secure retreat for the winter, and accordingly alter having completed this chamber, she no longer 
made excursions to catch the flies with which I supplied her, but remained self-immured in her cell.*

It would be interesting to discover whether any of the spiders of this group (but which do not construct trap-door nests) pass the winter in similar structures.

\section{H.}

\section{On the Structure of Cor, Doors.}

In order to test my theory to the effect that the trap-door nests are enlarged from time to time, and that the numbers of layers of silk in an undisturbed cork door should represent the number of enlargements which the nest has undergone, I examined the doors of twenty-eight nests of the cork type (all I believe of $N$. camentaria), in order to prove whether as a rule the larger cork doors do contain more layers of silk than the small ones, as they should on this hypothesis.

'T'his is, I think, fairly established by the following table :-

Comparative Table.

One cork door measuring 1 line across contained 1 layer of silk.

\begin{tabular}{|c|c|c|c|c|c|c|}
\hline Four & $"$ & doors & $"$ & $1 \frac{1}{2}$ lines & ," & \\
\hline One & ," & door & " & $1 \frac{1}{2}$ & ", & 2 \\
\hline One & , , & door & , & $1 \frac{3}{4}$ & ", & 4 \\
\hline One & ," & door & ", & 2 & ", & 5 \\
\hline Two &, & doors & ", & $2 \frac{1}{2}$ & ", & 6 \\
\hline One & , & door & , & $2 \frac{1}{2}$ & $"$, & 5 \\
\hline One & ,", & door & , , & 3 & , & 8 \\
\hline Two & , & doors & , & $3 \frac{1}{2}$ & , , & 5 \\
\hline One & , & door & ", & $3 \frac{1}{2}$ & , & 7 \\
\hline One & , & door & , & 4 & ", & 7 \\
\hline Two & , & doors & ", & $4 \frac{1}{2}$ & $"$ & 8 \\
\hline One & ", & door & ", & $4 \frac{1}{2}$ & , & 7 \\
\hline Two & ", & doors & ," & 5 & ", & 9 \\
\hline One & $"$ & door & $"$ & 5 & ", & 5 \\
\hline One & " & door & $"$ & 5 & $"$ & 6 \\
\hline One & ", & door & " & 5 & ", & 13 \\
\hline One & $"$ & door & $"$ & $5 \frac{1}{2}$ & $"$ & 9 \\
\hline One & $"$ & door & $"$ & $5 !$ & $"$ & 10 \\
\hline One & , & door & , & $5 \frac{1}{2}$ & $"$ & 14 \\
\hline One & , & door & $"$ & 6 & ", & 12 \\
\hline
\end{tabular}

* My observations on the captive spider were still in progress at the time of going to print, so that the above notes must be considered as incomplete. 
The apparent exceptions to this rule, in which the larger doors have fewer layers than some of the smaller ones, may probably be accounted for in the following manner. :

During the heavy rains and in times of drought flakes of earth often become detached from the sloping banks, and carry away the doors of such nests as are found in them.

This happens frequently, and the spiders hasten to repair the damage and spin new doors.

But I have found, on examining eight of these new doors, that, even in large nests, ${ }^{*}$ they do not then contain more than three layers of silk; so that each time a nest of any size loses its door, the number of layers is greatly reduced.

In the case of six of these nests I had myself acted the part of the landslip and removed the existing door. These original and apparently undisturbed doors measured $3 \frac{1}{2}, 4,5$, 5,5 , and 5 lines across, and contained respectively $5,7,8,13$, 9 and 5 layers of silk; while of the equally large doors which replaced them five contained three layers of silk only, and the remaining nest but a single layer.

* Of the eight doors in question the smallest measured $3 \frac{1}{2}$ lines across, and the largest 7 lines. 



\section{N D E X.}

\section{PART I.-HARVESTING ANTS.}

Elian on harvesting ants, 7-9.

Aldrovandus, radicle of seed gnawed by ants, 9 .

Algiers, harvesters observed in, 52 .

Aphides and cocci not sought by harresting ants, 48 .

AтTA barbara, 15, \&c.; barbara var., 16, 31, 63; barbata, 12 ;

cephalotes, 13; diffusa, 12 (note), 65; megacephala, 16, working at night, 49 ; providens, 12 (note), 65; rufa, 12 (note), 64; structor, $16,29,63$, working at night, 49 .

Battles of ants between different colonies of the same species, 37, 40; with caterpillar, 41.

Capri, harvesting ants at, 68 .

Captive ants, 42-49.

Crematogaster scutellaris, 62 ; sordidulus, 63.

Dispersal of seeds by means of ants, $4,21,53,55$.

Distribution of harvesting ants, $52,57,59$.

Enemies of the ants, 56 .

Forvica cruentata, 37, 61; cursor, 62; emarginata, 61, working at night, 49 ; erratica, 37,62 ; fusca, 51, 61 ; marginata, 62 ; nigra 5 (note); nigerrima, 52 ; viatica, 52 .

Galls found in ants' nests, 36 .

Germination of seeds arrested by ants, 20, 25, 26, 40; this fact mentioned by Aldrovandus, 9 .

Grunaries, structure of, 22, 23, 31, 32, 49, 54; position of, 31 ; contents of, 27 ; time required to construct, 45 .

Insects inhabiting ants' nests, $35,36,56$.

Jerdon (Dr.) on harvesting ants in India, 12, 64, 65. 
Kirby and Spence, assertion that ants do not harvest in Europe, 10.

Mistakes made by ants, 19,37 .

Mouth organs of ants, 48.

Mүrмica coespitum, 37, 51, 63.

Occasional harvesters, 51.

Economa cephalotes, 13; diffusa, 12 (note), 65; providens, 12 (note), 65.

Pireidole megacepluala, $16,50,63$, working at night, 49 ; pallidula, $51,63$.

Pseudomirara mofonigra, 67.

Radicle of germinating seeds gnawed off by ants, 20, 25, 26; this fact mentioned by Aldrovandus, 9.

Rock nest, sandstone mined by ants, 32-35.

Rubbish heaps, materials which compose, $21,22,5.5$.

Sandstone mined by ants, the rock nests, 31-35.

Seeds, dispersal of, by means of ants, 4, 21, 53, 55; tendency to germinate arrested, 24,50 ; eaten by ints, 46-48, 54.

Seed stores of ants used as food by natives of India, 67 .

Spherical chamber fonnd in ant's nest, 35.

Sykes (Lient.-Col.) and Jerdon (Dr.) on harvesting ants in India, $12,64,65$.

Winged males and females of API. Structor and Barbar $\alpha, 41$.

\section{PART II.-TRAP-DOOR SPIDERS.}

Atrpes Blacliwallii, 78.

ATrpus piceus, 77 ; nest of, 78.

Ausserer (A.), description of NEMESIA manderstjernce, 145.

Australia, trap-cloor spiders in, 114, 130.

Blackwall, on nests of Atrpts piceus, 78 (note).

Blackwall, on the tarsi of certain spiders being furnished with a viscons secretion, 87 .

British representative of the sub-order Territelanie, 77.

Browne (Patrick), on the trap-door spider of Jamaica, $7: 3$.

Cambridge (Rev. O. Pickard), description of Ctensz foltiens, 89; of Nemesia comentaria, 92; of N. moridionalis, 101; of N. Elerenom, 108. 
Captive trap-door spiders, 118, 122, 143.

Claws, compared in different trap-door spiders, 86 ; retractile, 87 (note).

Construction of trap-door nests, 1.18, 122, 123, 149.

Cork nests, 80, 88, 94, 97, 116, 124, 131, 132, 141.

Costa (O. G.), on MYgale (NeyesIA) meridionalis, 105, 137.

Ctexizs ariana, 115, 135, 141 ; cedificatorius, 85; fodiens, 89; ionica, 91 ; nidulans, 81 .

Double-door branched nest, 80, 98, 103-106, 131.

Double-door unbranched nest, 80, 98, 106, 111, 131.

Dufour (Léon), on the nest of Lrcosa tarentula, 146.

Enemies of spiders, 101, 134.

Epeira fasciata, cocoon of, 76.

Erber, on the nocturnal habits of CTExiza ariana, 115, 135, 141.

Geographical range of species of trap-door spiders, 131, 132, 133, 143.

Gosse (P. H.), on the single-door wafer nest in Jamaica, 80-83.

Instinct (?) of nest building in rery young spiders, $123,126,128$.

Lucas (H.), on spiders having retractile claws, 87.

Lrcosi tarentula, M. Dufour on the nest of, 146.

Male of Nenessa Eleanora, 109, 11\%.

Mrgalide, name changed to Territelarie, 75 .

Nenesia ccementaria, 73, 92, 97, resisting when the door is touched, 94-96; cellicola, 141, 147, 118 ; Eleanora, 98, 106, 108, 112; Manderstjerno, 147; meridionalis, 98, 101, 137.

Nest of Lrcosi tarentula, 146 .

Nocturnal habits of trap-door spiders, 115, 116.

Olivier, on cork nests at Hyères, 115.

Rossi (P.), on Ctexiza fortiens, 73.

Resistance of spiders when doors are touched, 94-96, 100, 112.

Saunders (S. S.), on Ctexiza (Mygale) ionica, 91, 122.

Sauvages (Abbé), on Neuesia camentaria, 73.

Selection of materials for trap-doors, 11!, 120.

Sells (W.), on the nest of CTExIZA niduluns, 83.

Single-door wafer nests, 80, 131.

Tarsi of spiders furnished with a riscous secretion, enabling them to traverse perpendicular polished surfaces, 87.

Territelari.: a sub-order of Araxem, formerly called Mrgalid.玉, 75. 
Territelarie, species of, inhabiting the Mediterranean region, 130, $131,133,148$.

Theridion, cocoon of, 77.

Trap-door nests enlarged not abandoned, 123, 127, 150.

Walckenaer (C. A. de) on habits of trap-door spiders, 114, 117; on structure of cork doors, 125 (note).

Wallace (A. R.) on the philosophy of birds' nests, 129.

West Indian nests of the single door wafer type, 80 .

Westwood (Prof.) on the nest of CTENiza aedificatorius, 85.

Young spiders found in rests of Nexesta meridionalis and $\mathrm{N}$. Eleanora, 112. 


\section{9.}

